\title{
(स)
}

INSTITUTO DE PESQUISAS ENERGÉTICAS E NUCLEARES

Autarquia Associada à Universidade de São Paulo

Recusas e demoras no transporte de materiais radioativos

\section{DANIELA CAMPOS}

Dissertação apresentada como parte dos requisitos para obtenção do Grau de Mestre em Ciências na Área de Tecnologia Nuclear - Aplicações

Orientador:

Prof. Dr. Gian Maria Agostino Angelo Sordi Coorientador:

Profa. Dra. Janete Cristina Gonçalves Gaburo Carneiro

Versão original

São Paulo 2019 
INSTITUTO DE PESQUISAS ENERGÉTICAS E NUCLEARES

Autarquia Associada à Universidade de São Paulo

Recusas e demoras no transporte de materiais radioativos

DANIELA CAMPOS

Dissertação apresentada como parte dos requisitos para obtenção do Grau de Mestre em Ciências na Área de Tecnologia Nuclear - Aplicações

Orientador:

Prof. Dr. Gian Maria Agostino Angelo Sordi Coorientador:

Profa. Dra. Janete Cristina Gonçalves Gaburo

Carneiro

São Paulo 
Autorizo a reprodução e divulgação total ou parcial deste trabalho, para fins de estudo e pesquisa, desde que citada a fonte

Como citar:

CAMPOS, D. Recusas e demoras no transporte de materiais radioativos. 2019. 132 p. Dissertação (Mestrado em Tecnologia Nuclear), Instituto de Pesquisas Energéticas e Nucleares, IPEN-CNEN/SP, São Paulo. Disponível em:

$<w w w . t e s e s$.usp.br $>$ (data de consulta no formato: $\mathrm{dd} / \mathrm{mm} / \mathrm{aaaa}$ )

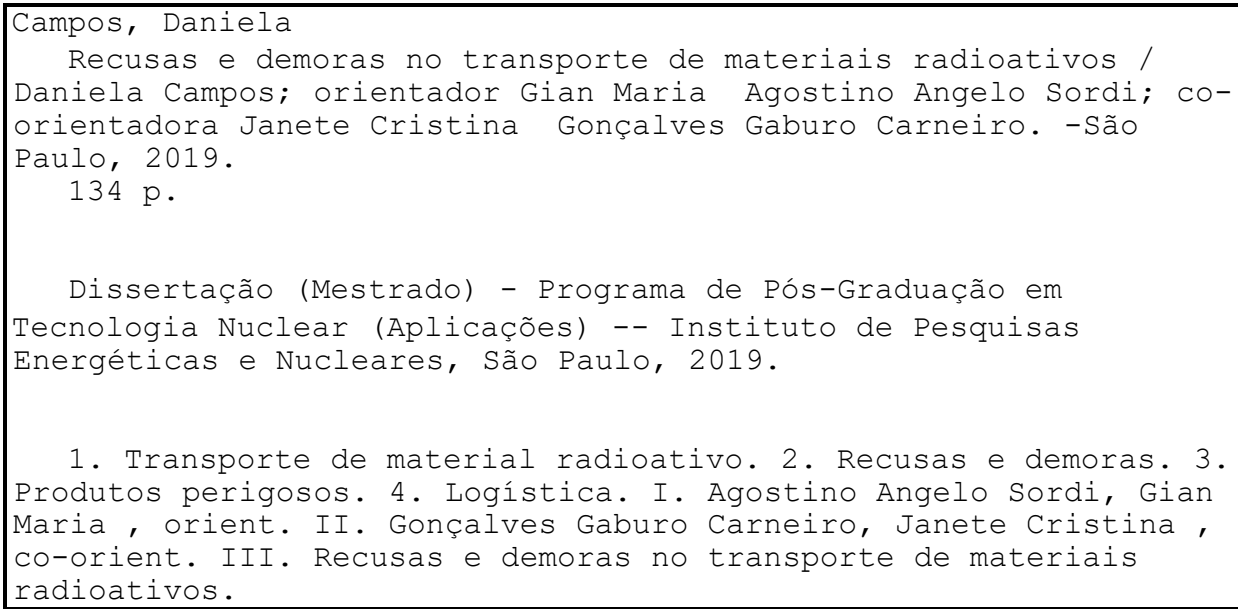




\section{FOLHA DE APROVAÇÃO}

Autor: Daniela Campos

Título: Recusas e demoras no transporte de materiais radioativos

Dissertação apresentada ao Programa de Pós-graduação em Tecnologia Nuclear da Universidade de São Paulo para obtenção do Grau de Mestre em Ciências na área de Tecnologia Nuclear.

\section{BANCA EXAMINADORA}

Dr. Gian Maria Agostino Angelo Sordi

Instituto de Pesquisas Energéticas e Nucleares

Parecer:

Dra. Luciana Maria Gasparelo Spigolon Frollini

Faculdade de Tecnologia do Estado de São Paulo

Parecer:

Dra. Maria Inês Calil Cury Guimarães

Universidade de São Paulo

Parecer: 


\section{AGRADECIMENTOS}

Ao meu orientador, Dr. Gian Sordi, pelo apoio, didática e paciência sem iguais durante a produção deste trabalho.

A minha co-orientadora, Dra. Janete Carneiro, por todo auxílio prestado.

A Demerval Leônidas Rodrigues e Natanael Barros, que apoiaram e contribuíram grandemente com a dissertação.

Ao Instituto de Pesquisas Energéticas e Nucleares, pela oportunidade de desenvolvimento do trabalho.

A todos participantes respondentes dos questionários e entrevistas que tornaram esta pesquisa possível, em especial ao major Eronides Lima Pereira, tenente Ataliba Barbosa e a todos os participantes do Exército Brasileiro.

Aos transportadores de material radioativo, protagonistas deste tema e que tanto contribuíram para o levantamento de informações.

A minha família e amigos pela compreensão e incentivo nesta jornada.

A todos que podem não estar citados, mas contribuíram direta ou indiretamente para a realização deste trabalho. 


\section{RESUMO}

CAMPOS, D. Recusas e demoras no transporte de materiais radioativos. 2019. 134 p. Dissertação (Mestrado em Tecnologia Nuclear), Instituto de Pesquisas Energéticas e Nucleares, IPEN-CNEN/SP, São Paulo.

O material radioativo é classificado pela Organização das Nações Unidas (ONU) como produto perigoso e enquadra-se na classe 7. Seu transporte é necessário para diversas atividades na indústria, agricultura, saúde etc. Recusas e demoras durante o transporte são caracterizadas pelo evento em que a carga, mesmo possuindo as condições ideais para o transporte, teve problemas. Podemos citar como exemplo a rejeição do material por autoridades fiscais quando a carga está totalmente regular ou por exigência de procedimentos de proteção que não estão presentes em norma. Os acontecimentos geram prejuízos financeiros e de imagem social a empresas prestadoras de serviço especializado, hospitais, usuários do material, empresas de geração de energia elétrica e outros. Este trabalho realizou o levantamento dos motivos causadores das recusas e demoras no país por meio de revisão da literatura, entrevistas e questionários, descreveu as soluções obtidas em alguns casos e propôs ações para resolução dos casos em aberto. O medo da radiação ionizante durante o transporte foi mensurado através análises estatísticas de um questionário aplicado a dois grupos de estudo (Grupo 1 e Grupo 2), compostos por indivíduos envolvidos no transporte de materiais radioativos e de outros produtos perigosos. Testes de análise fatorial exploratória, confiabilidade de escala, consistência interna por alfa de Cronbach e correlação foram aplicados para validação dos dados, que são demonstrados por histogramas e estudo de quartis. Dentre os motivos causadores de recusas e demoras encontrados, estão a dificuldade de adaptação às normas vigentes, excessividade e contradição das normatizações, o treinamento específico insuficiente, a indisponibilidade de transportadoras e o medo da radiação ionizante. O estudo realizado para confirmação do medo da radiação durante o transporte foi positivo, indicando a presença do medo durante o processo logístico, como descrito em alguns documentos nacionais e internacionais. Por ser um problema multifatorial, a resolução das recusas e demoras depende de ações como a harmonização das normatizações, mudança na grade curricular de cursos de formação específica, melhora na divulgação de informação e 
levantamento das ocorrências de recusa e demora e alterações específicas nas normas que facilitem o processo de transporte sem, no entanto, reduzir sua segurança. A insuficiência de recursos financeiros e humanos e a diversidade de órgãos regulatórios envolvidos nesta questão dificultam sua resolução. Porém, o país conta com a experiência adquirida nos últimos 9 anos pelo Comitê Brasileiro sobre Recusas e Demoras no Transporte de Materiais Nucleares e Outros Materiais Radioativos, que fornece um grande potencial de redução dos problemas em médio prazo e viabilidade de sua extinção a longo prazo, que dependem basicamente do levantamento de recursos humanos e financeiros para esta finalidade.

Palavras-chave: transporte de material radioativo, recusas e demoras, produtos perigosos, logística. 


\section{ABSTRACT}

CAMPOS, D. Denials and delays on radioactive material shipment. 2019. 134 p. Dissertação (Mestrado em Tecnologia Nuclear), Instituto de Pesquisas Energéticas e Nucleares, IPEN-CNEN/SP, São Paulo.

Radioactive material is classified as a dangerous good and falls into Class 7. Its transportation is necessary for different activities in industry, agriculture and health. Denials and delays during transportation are characterized by an event where the cargo had the ideal conditions for transportation and still had problems. May be cite as an example the rejection of the material by fiscal authorities when the cargo is totally regular, or the requirement of protection procedures that are not present in standards. The events generate financial and social image damages to companies providing specialized service, hospitals, users of the material, electric power generation companies and others. This paper surveyed the reasons for denials and delays in the country by literature review, interviews and questionnaires, described the solutions obtained in some cases and proposed actions to solve open cases. Fear of ionizing radiation during transport was measured by statistical analyzes of a questionnaire applied to two study groups (Group 1 and Group 2), composed of individuals involved in the transport of radioactive materials and other dangerous goods. Exploratory factor analysis, scale reliability, internal consistency by Cronbach's alpha and correlation tests were applied to validate the data, which are demonstrated by histograms and quartiles study. The reasons for denials and delays include the difficulty of adapting to current norms, excessiveness and contradiction of regulations, insufficient specific training, unavailability of carriers and fear of ionizing radiation. The study conducted to confirm the fear of radiation during transport was positive, indicating the presence of fear during the logistics process, as described in some national and international documents. As a multifactorial problem, its resolution depends on actions such as harmonization of regulations, changes in the curriculum of specific training courses, improvement in the dissemination of information, betterment on survey of occurrences of denials and delays and specific changes in the standards to facilitate the transportation process without, however, reducing their safety. The lack of financial and human resources and the 
diversity of regulatory organisms involved in this issue makes it difficult to resolve them. With the experience gained in the last 9 years of the Brazilian Committee for Denials and Delays in the Radioactive Materials Transport, there is a great potential for reducing the problems in the medium term and the feasibility of their extinction in the long term, which basically depends on the collection of human and financial resources for this purpose.

Key words: radioactive material shipment, denials and delays, dangerous good, logistics. 


\section{LISTA DE TABELAS}

Título

Página

Tabela 1 - Análise fatorial exploratória para validação do questionário

Tabela 2 - Análise fatorial exploratória para validação do questionário adaptado

Tabela 3 - Valores de consistência interna por alfa de Cronbach

Tabela 4 - Dados quantitativos dos encontros do Comitê Nacional

Tabela 5 - Legislação vigente na regulamentação do transporte de materiais radioativos no Brasil em âmbito federal

Tabela 6 - Inconsistências entre a norma CNEN 5.01 e as Resolução ANTT $n=5.232$

Tabela 7 - Estruturação do curso MOPP e considerações sobre 0 conteúdo

Tabela 8 - Carga horária mínima dos cursos para formação no transporte de materiais perigosos no modal aéreo

Tabela 9 - Grade curricular para o EOCA

Tabela 10 - Gastos e funcionários da CNEN em 3 anos

Tabela 11 - Gasto da CNEN em comparação a inflação

Tabela 12 - Tabela de consequências de recusas e demoras no transporte de material radioativo

Tabela 13 - Radiofármacos transportados: utilização e valor comercial

Tabela 14 - Distribuição numérica dos Grupos 1 e 2 para o fator 1 102

Tabela 15 - Resumos numéricos dos Grupos 1 e 2 para o fator 2 


\section{LISTA DE GRÁFICOS}

Título

Página

Gráfico 1 - Modais de transporte utilizados

Gráfico 2 - Eventos de recusas e demoras em 12 meses

Gráfico 3 - Eventos de recusas e demoras em 5 anos

Gráfico 4 - Situações já enfrentadas pelas empresas entrevistadas

Gráfico 5 - Modal de transporte com maior incidência de problemas na empresa respondente

opinião do respondente

Gráfico 8 - Prejuízos não financeiros sofridos pelas empresas

Gráfico 9 - Comparação de histogramas: fator 1

Gráfico 10 - Comparação de histogramas: fator 2 


\section{LISTA DE FIGURAS}

Título

Figura 1 - Esquema do Questionário 1 e seus indicadores

Figura 2 - Questionário 1 adaptado após análise fatorial

Figura 3 - Redução de transportadoras marítimas ao longo dos anos
Página

28

33

68 


\section{SUMÁRIO}

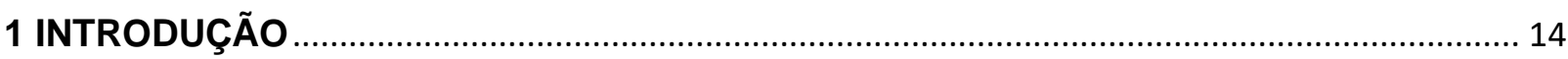

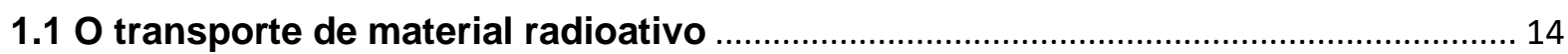

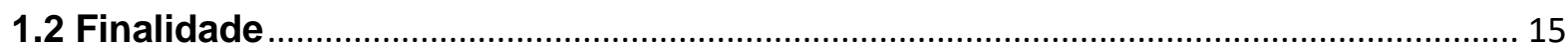

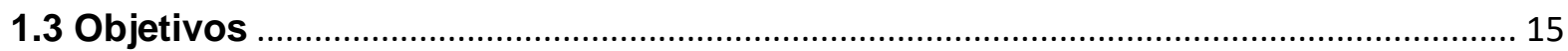

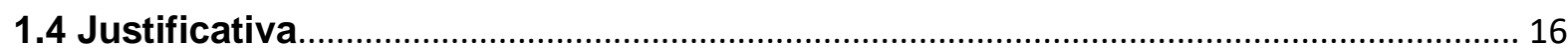

2 CONHECIMENTOS CIENTÍFICOS A RESPEITO DAS RADIAÇÕES IONIZANTES E DO

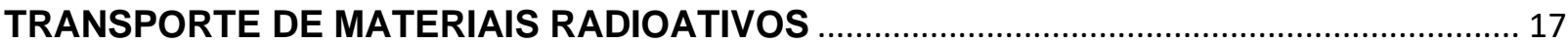

2.1 Conhecimentos sobre a radiação ionizante e a proteção radiológica....................... 17

2.2 Conhecimentos sobre o transporte de materiais radioativos..................................... 20

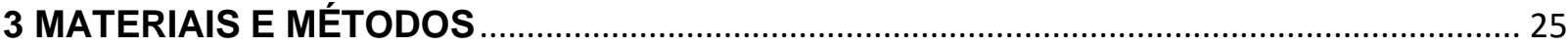

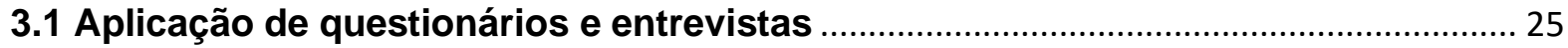

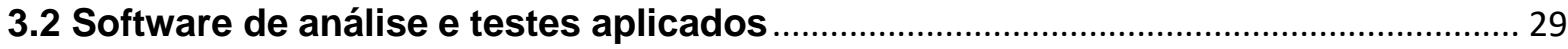

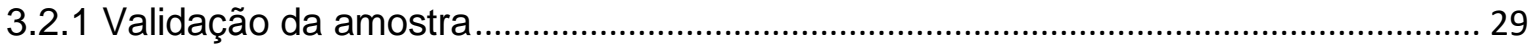

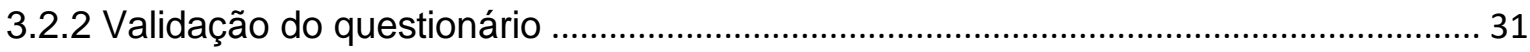

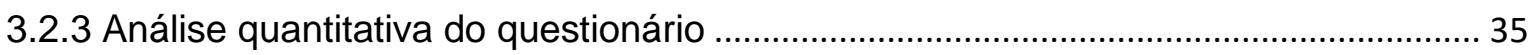

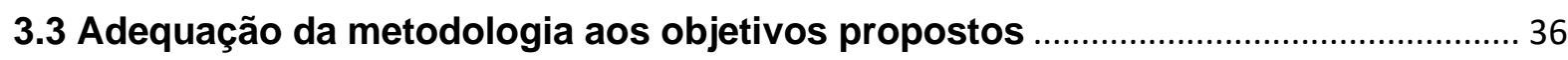

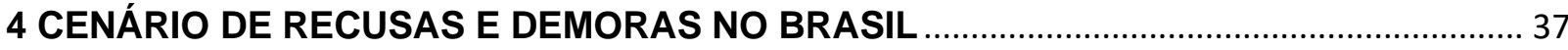

4.1 Motivos que acarretam recusas ou demoras no transporte de materiais

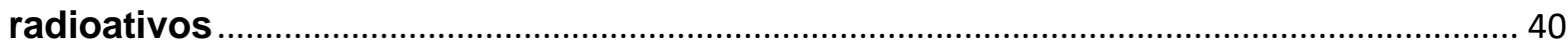

4.2 Recusas e demoras de acordo com o modal de transporte ..................................... 42

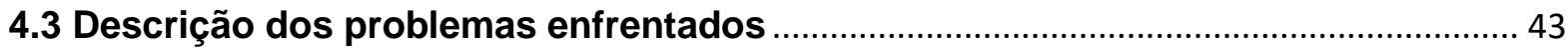

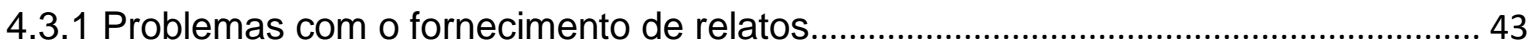

4.3.2 Processo burocrático e dificuldade de adaptação ......................................................... 45

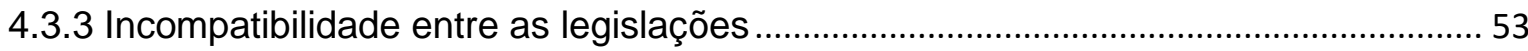

4.3.3.1 Dificuldades relatadas por divergências entre a norma CNEN 5.01 e outras

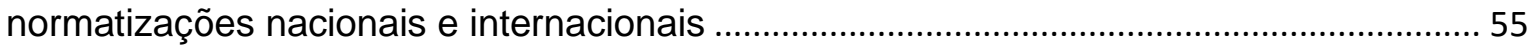

4.3.3.2 Dificuldades entre a legislação do município de São Paulo e demais legislações

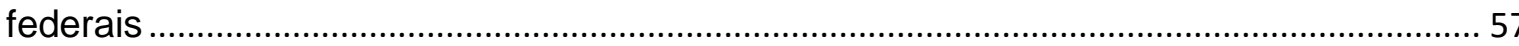

4.3.3.3 Dificuldades entre a legislação do estado de Minas Gerais e demais legislações

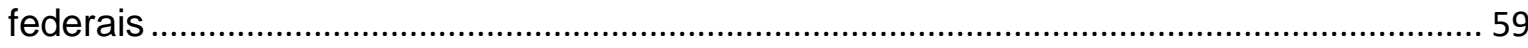

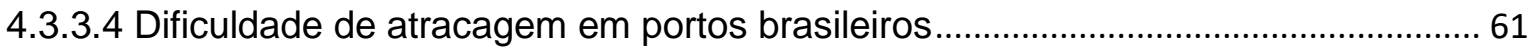

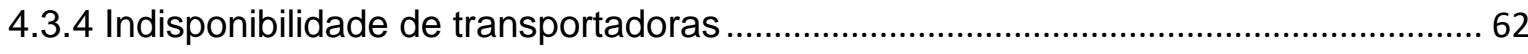

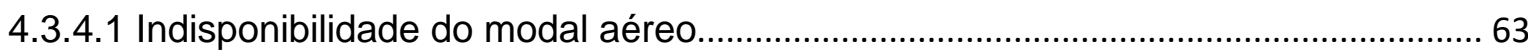

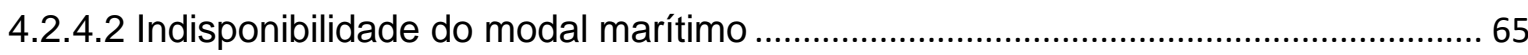


4.3.4.3 Indisponibilidade no modal terrestre.

4.3.5 Falta de conhecimento sobre o transporte de materiais radioativos .......................... 69

4.3.5.1 A educação nacional e o desafio da divulgação de informação ................................ 72

4.3.6 Indisponibilidade de recursos para lidar com todos os problemas ............................. 84

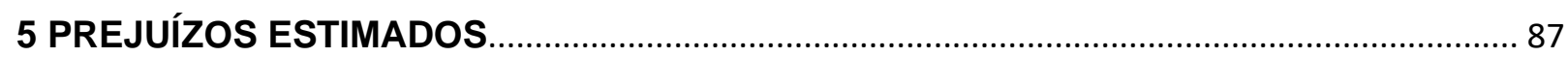

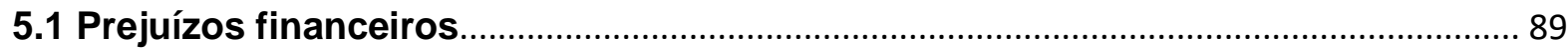

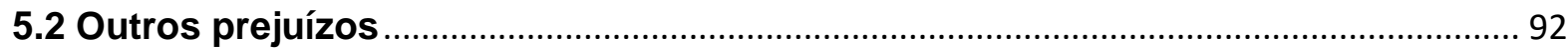

6 ESFORÇOS PARA SOLUCIONAR OS PROBLEMAS MENCIONADOS NO CAPÍTULO 4: AÇÕES DO COMITÊ NACIONAL DE RECUSAS DE DEMORAS ........................................... 95

6.1 Esforços para redução dos problemas com a legislação ........................................... 96

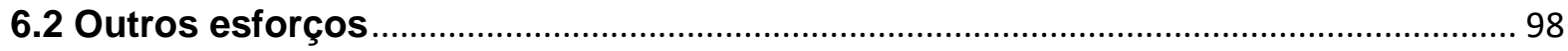

7 O MEDO DA RADIAÇÃO E O PROBLEMA DOS TRASNPORTES …................................ 100

8 DISCUSSÃO E SUGESTÃO DE SOLUÇÕES .................................................................. 106

8.1 Sugestões para resolução dos problemas do transporte aéreo ............................... 106

8.2 Comunicação e divulgação de informação ................................................................ 107

8.30 problema regulamentar e burocrático .................................................................... 108

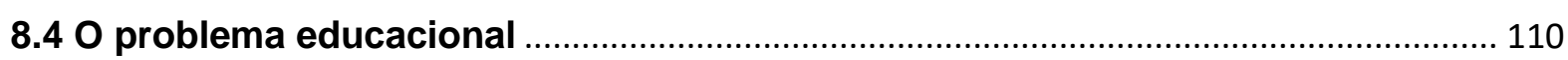

8.5 Medo da radiação ionizante no transporte ................................................................. 112

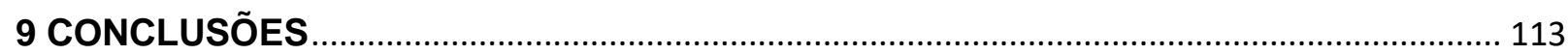

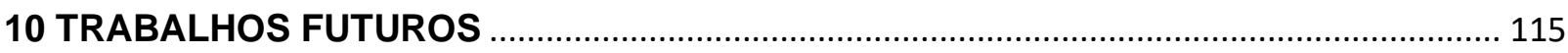

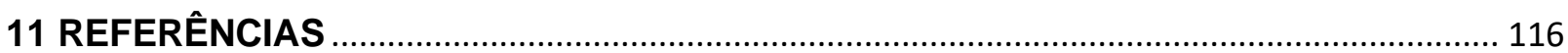

APÊNDICE A - Termo de Consentimento Livre e Esclarecido (TCLE).............................. 123

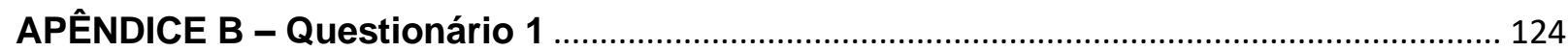

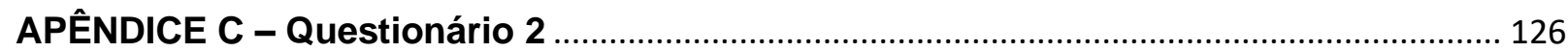

ANEXO 1 - Formulário oficial para relato de recusas e demoras …................................. 127

ANEXO 2 - Grade curricular sugerida para o curso de artigos perigosos ANAC........... 129

ANEXO 3 - Cronograma do curso de artigos perigosos ANAC ......................................... 130

ANEXO 4 - Tabela das necessidades de formação traduzida do Código IMDG ............. 132 


\section{INTRODUÇÃO}

\subsection{0 transporte de material radioativo}

O transporte de material radioativo é uma etapa presente e importante em atividades como a produção de energia nuclear, aplicações médicas para diagnóstico e tratamento de enfermidades, aplicações industriais, na agricultura etc. Como todo produto, o material radioativo necessita ser transportado do local de fabricação até o consumidor final. Dezenas de milhões de transportes de materiais radioativos são realizados a cada ano no mundo $[1,2]$.

O material radioativo é tratado como produto perigoso e, pela Comissão Econômica das Nações Unidas (CENU), enquadra-se na classe 7 [3, 4]. Assim, seu transporte fica submetido às normatizações referentes aos produtos perigosos vigentes no país de origem do material e também dos demais países que ele percorra durante 0 transporte. As normas podem variar e se complementarem nos modais terrestre, aquático ou aéreo dependendo do órgão regulador específico, além de outros regulamentos ambientais caso haja risco de contato com a atmosfera ou água durante o transporte. Também devem ser assegurados o cumprimento e obedecidas demais normas de proteção radiológica, monitoração individual e coletiva e programas de qualidade referentes a expedições de material radioativo [3]. Apesar de massivas, estas normas possuem um único objetivo comum: proporcionar a padronização e garantir a segurança durante o transporte de produtos perigosos $[1,4,5,6]$.

Dentro deste contexto, surge o problema de recusas e demoras no transporte de materiais radioativos, que origina prejuízos financeiros e de imagem social a empresas prestadoras de serviço especializado, hospitais, usuários do material e empresas de geração de energia elétrica. Considera-se recusa ou demora no transporte de material radioativo o evento em que a carga possuía as condições ideais para o transporte, porém, ainda assim, teve problemas. Pode-se citar como exemplo uma carga de material radioativo em que todos os parâmetros estão regulares: segurança, documentação, sinalização etc. e ainda assim é rejeitada por um piloto, por uma transportadora, fiscal ou autoridade portuária. 
Por décadas, o transporte de material radioativo tem sido realizado de maneira eficiente e segura. Isso se deve à eficácia na aplicação das normas regulatórias e competência coletiva das entidades envolvidas nesse tipo de transporte. Apesar das excelentes condições, uma preocupante tendência tem sido exposta nos últimos anos: companhias de transporte de diversos modais e portos instituíram políticas de não aceitarem o material radioativo (classe 7) [2].

Discutido pela primeira vez em 2003, o problema fez com que o Organismo Internacional de Energia Atômica (OIEA) criasse o Comitê Diretivo Internacional de Recusas e Demoras (Internal Steering Comittee - ISC) [1, 7]. Por orientação do OIEA, o Brasil estabeleceu o Comitê Brasileiro sobre Recusas e Demoras no Transporte de Materiais Nucleares e Outros Materiais Radioativos (referido neste trabalho como Comitê Nacional) em 2010, com o apoio da Associação Brasileira de Ensaios Não Destrutivos e Inspeções (ABENDI) e da Diretoria de Radioproteção e Segurança Nuclear (DSR) da CNEN [7].

As recusas e demoras no transporte de materiais radioativos tem múltiplos motivos, mas que derivam, em sua maioria, da percepção errônea sobre a origem do material radioativo e os requisitos para o transporte seguro. Os problemas podem impactar nas segurança e saúde públicas, gerar encargos e problemas logísticos variados [2].

\subsection{Finalidade}

Este trabalho examinou os motivos que acarretaram as recusas e demoras reportados e, em caso de resolução, como foram solucionados. Do contrário, investigou-se o que já foi realizado e o porquê não se obteve sucesso. Neste último caso, sugeriu-se novas soluções.

\subsection{Objetivos}

Para alcançar a finalidade proposta foram executados os seguintes objetivos: 
1. Um levantamento bibliográfico a respeito do que a literatura científica já registrou com relação a recusas de transporte de materiais radioativos.

2. Um levantamento de dados por meio de depoimentos de pesquisadores da área e representante dos meios de transporte procurando desvendar seus conhecimentos com relação ao assunto "recusas e demoras no transporte de materiais radioativos".

3. A análise detalhada das recusas encontradas e, se possível, efetuar uma classificação entre elas.

4. Um estudo das soluções reportadas para as recusas vencidas.

5. Conhecendo as soluções reportadas para as recusas vencidas, a proposição de soluções para aquelas que ainda se encontram em estudo.

\subsection{Justificativa}

Por se tratar de um assunto muito prático, pouco se encontra na literatura a respeito das recusas e demoras no transporte de materiais radioativos no país. Apesar de ser um tema discutido, oficialmente, desde 2010 em âmbito nacional [7], as únicas fontes de informação são os relatórios do Comitê Nacional. Estes relatórios, em sua maioria, não são disponibilizados ou de fácil acesso ao conhecimento público. Entendese que, por vezes, o acesso restrito se faz necessário para proteger a imagem de empresas e personalidades envolvidas no processo de solução dos problemas e informações comerciais importantes as empresas participantes nas reuniões. Assim, este documento visa abordar o tema de forma mais ampla, contribuído para a disponibilidade do conteúdo de acesso público, evidenciando o cenário nacional, a evolução do problema ao longo dos anos e suas perspectivas de banimento. 


\section{CONHECIMENTOS CIENTÍFICOS A RESPEITO DAS RADIAÇÕES IONIZANTES E DO TRANSPORTE DE MATERIAIS RADIOATIVOS}

Para se conceber as embalagens corretas e para que o transporte de material radioativo seja realizado em segurança é necessário conhecer diversos campos científicos envolvidos na proteção radiológica. Os conhecimentos em proteção radiológica são muito extensos e estão divididos em campos de aplicação, como reatores nucleares, aplicações médicas, produção de radiofármacos, transportes, efeitos biológicos, mineração, metrologia das radiações, entre outros [8]. No entanto, acredita-se que para o transporte de material radioativo somente alguns assuntos são necessários ao pesquisador, de forma que este possa compreender sem dificuldades a sua operacionalização. Assim, segue um resumo das partes que se julga mais importantes.

\subsection{Conhecimentos sobre a radiação ionizante e a proteção radiológica}

Os materiais radioativos compõem a classe 7 dos materiais perigosos por serem nocivos à saúde humana [4]. Neste caso, é primordial conhecer os seus malefícios à saúde. Esta disciplina é conhecida como "efeitos biológicos da radiação ionizante". Estes efeitos biológicos são classificados em duas categorias, os probabilísticos e os não probabilísticos. Os probabilísticos geralmente são tardios e se manifestam em forma de cânceres e efeitos hereditários, são denominados efeitos estocásticos. Os não probabilísticos possuem sempre uma dose limiar, isto é, uma dose abaixo da qual a patologia não se manifesta no indivíduo, são conhecidos como efeitos ligados ao tecido ou determinísticos [9].

Uma vez que conhecemos os efeitos biológicos, devemos conhecer que quantidades de radiação ionizante os produzem. Razão pela qual devemos introduzir um sistema de grandezas físicas e unidades capazes de avalia-los.

$\mathrm{Na}$ realidade, o que podemos medir por meio de instrumentação adequada é o tipo de radiação ionizante e sua energia ou espectro de energia. Dependendo do tipo de radiação, isto é, alfa, beta, prótons etc. quantidades diferentes de energias 
produzem o mesmo efeito biológico. Desta maneira, mede-se a energia absorvida pelo corpo humano e multiplica-se por um fator conhecido como "de ponderação", que fornece um número que representa a patologia. Portanto, este número depende do tipo de radiação e do seu espectro de energia. Esta disciplina é conhecida como "dosimetria das radiações ionizantes" [10].

Após isto, deve-se estabelecer um sistema de limitação de dose como o intuito que o indivíduo não seja portador de enfermidades causadas pela radiação ionizante durante toda a sua vida. Este sistema está baseado em três princípios, contidos na norma 3.01 da CNEN [10], conhecidos como:

a) Princípio da justificação: toda exposição, para fins médicos ou não, deve trazer benefício para o indivíduo exposto ou para a sociedade, de forma que a exposição e os riscos trazidos por ela sejam justificáveis.

b) Princípio da otimização: as exposições causadas por uma ou mais fontes associadas a uma prática devem ser otimizadas, de forma que a exposição atinja seu objetivo com valores tão baixos quanto possa ser racionalmente exequível considerando-se aspectos sociais e econômicos.

c) Princípio da limitação de dose: exceto para exposições médicas (exposição de pacientes para diagnóstico e tratamento), a exposição normal dos indivíduos deve ser restringida de forma que não ultrapassem o valor estabelecido pelas normas da CNEN.

Se uma fonte de radiação ionizante fornecer doses superiores aos limites devemos aplicar uma proteção para que os indivíduos obedeçam aos seus limites. Em condições normais de trabalho, a proteção pode ser realizada de três maneiras, a saber:

I) Limitando o tempo de permanência do indivíduo próximo à fonte de radiação.

II) Aumentando a distância entre a fonte de radiação e o indivíduo exposto.

III) Fornecendo barreiras que blindam a radiação entre a fonte e o indivíduo exposto.

Com relação à distância, em princípio, sabe-se que a radiação se atenua com o inverso do quadrado da distância e, portanto, esta proteção torna-se eficaz no 
primeiro metro de distância e não mais. Exemplificando, se ficarmos a 1 centímetro de distância da fonte e ela fornecer uma dose $\mathrm{A}$, a um metro fornecerá uma dose de $\mathrm{A} / 100^{2}$ $=A / 10.000$, isto é, diminuirá de um fator 10.000. Mas quando passamos de 1 metro para 4 metros, o decréscimo de radiação será de $4^{2}=16 \mathrm{e}$, trabalhar-se a 4 metros de distância da fonte seria difícil pois considera-se que o comprimento do braço é de 70 centímetros. Assim, a solução seria o uso de uma garra ou uma pinça de 30 centímetros de comprimento durante a manipulação da fonte, totalizando 1 metro de distância entre a região do tronco do indivíduo e a fonte. Mesmo que as mãos e os braços fiquem a uma distância menor em relação à fonte, estes possuem um limite de dose maior, já que sua sensibilidade à radiação ionizante é inferior àquela dos órgãos contidos no tronco [10,11].

Se estes dois sistemas de proteção não forem suficientes, torna-se necessário introduzir barreiras entre a fonte e o indivíduo exposto que absorverão a radiação. Neste caso, deve-se considerar duas situações derivadas do trabalho. As situações normais, nas quais protege-se a fonte por meio de blindagens ou o meio ambiente, deduzindo os caminhos da radiação até chegar ao indivíduo, reduzir as suas doses ou, por fim, protegendo o indivíduo pelo uso de equipamento de proteção individual (EPI). Em caso de situações anormais de trabalho, isto é, situações que poderiam levar a acidentes e emergências, a proteção radiológica é realizada de maneira diferente e é conhecida como defesa em profundidade. Exemplificando, o reator IEA-RI do Instituto de Pesquisas Energéticas e Nucleares (IPEN) possui 5 barreiras em profundidade, a saber: água da piscina em que o material combustível se encontra, paredes da piscina, prédio do setor em que ele se encontra, portaria do prédio e prédios vizinhos e a portaria geral do IPEN. Este campo de proteção é conhecido como "engenharia de proteção" [12].

Uma vez que temos uma proteção adequada que satisfaça o sistema de limitação de dose, devemos ter a certeza que ela continua adequada com o transcorrer do tempo, isto é, que com o passar do tempo ela não deteriore. Isto é conseguido por meio das técnicas de monitoramento. Para tanto, faz-se uso de equipamento de monitoração. Podemos monitorar tanto o indivíduo como o seu ambiente de trabalho [10]. 
A presença de material radioativo pode provocar situações anormais de trabalho que contaminam tanto o seu ambiente como o indivíduo e, desta maneira, deve-se ter conhecimento de procedimentos de descontaminação. De tudo isto, podem resultar rejeitos radioativos que devem ser tratados e depois eliminados de maneira segura $[10,13]$.

\subsection{Conhecimentos sobre o transporte de materiais radioativos}

Após os tópicos anteriores, deve-se conhecer alguns aspectos mais específicos sobre o transporte de materiais radioativos. Para este trabalho, considerase necessário saber: os diferentes tipos de embalagens das fontes de radiação para o transporte seguro, a legislação vigente e a dinâmica de funcionamento do transporte da classe 7.

Para promover a segurança durante o transporte de materiais radioativos, a CNEN especifica em sua norma 5.01 [4] os padrões de qualidade dos embalados, a limitação de atividade por embalado e por unidade transportadora e as condições ambientais a que os embalados podem ser expostos durante as operações normais. Também abrange informações sobre os projetos de fabricação das embalagens, seus ensaios e manutenções, manuseio, preparação, expedição, carregamento e armazenagem do material radioativo durante 0 transporte. Especifica as responsabilidades inerentes ao expedidor e ao transportador e dá orientações sobre o transporte de embalagens vazias. Assim, torna-se a principal referência para o transportador e para os envolvidos no transporte [4].

Sobre as embalagens que transportam o material radioativo, estas são classificadas em quatro tipos, ou, como são chamadas, quatro tipos de embalados: os exceptivos, os industriais, os do tipo A e os do tipo B. Cada embalado é apropriado para um certo tipo de material radioativo e escolhido de acordo com atividade que irá conter. Também se consideram aspectos como a fissilidade do material e a presença de outras características perigosas. Além disto, os embalados possuem requisitos que devem ser seguidos, como, por exemplo, serem fácil e seguramente manuseáveis e transportáveis, possam ser adequadamente fixados no meio de transporte, sejam capazes de resistir os efeitos da aceleração, vibração ou ressonância de vibração possíveis durante o transporte de rotina, entre outros [4]. 
A legislação vigente é um dos motivos causadores das recusas e demoras no transporte de materiais radioativos. Por isso, uma análise mais profunda e detalhada do assunto é abordada no item 4.2 deste trabalho. Neste capítulo, cabe salientar alguns requisitos bem estabelecidos e que facilitam o entendimento do assunto principal ao longo da dissertação.

As normas nacionais e internacionais, além dos embalados, possuem um sistema de limitação de dose durante o transporte denominado Índice de Transporte (IT). O IT é um número atribuído a um embalado, a um pacote de embalados, tanque ou contêiner que contenham material radioativo. Seu propósito é estabelecer, conforme aplicável:

a) O controle da exposição à radiação e da criticalidade nuclear: para isto, o IT vale-se do item b;

b) Limites de conteúdo radioativo: impõe uma quantidade de material ou atividade máxima que podem ser transportados em um único embalado, em vários pacotes em um veículo, contêiner ou embarcação;

c) Categorias para rotulação: o rótulo do embalado ou sua categoria se adéqua conforme o IT;

d) Requisitos para uso exclusivo: chama-se de uso exclusivo um transporte que seja destinado, exclusivamente, ao transporte do material radioativo. Este transporte obedecerá às orientações do expedidor, exclusivamente. O IT dá a informação de quando o material necessita de transporte exclusivo;

e) Requisitos de espaçamento durante o armazenamento em trânsito: estabelece as distâncias a serem mantidas entre os materiais radioativos e entre o material radioativo e os demais materiais, conforme o IT;

f) Restrições e mistura durante o transporte realizado mediante aprovação especial de transporte e durante armazenamento em trânsito: em algumas situações, o material radioativo pode ser composto de mais de um isótopo, que pode ser físsil ou não. O IT estabelece as limitações de mistura entre os isótopos para fins de transporte;

g) O número de embalados permitido em um contêiner ou em um meio de transporte.

Para o cálculo do IT, na maioria dos casos, mede-se o Nível de Radiação Máximo (NRM) a um metro de distância da superfície do embalado. Caso expresso em 
milisieverts/hora, o valor obtido é multiplicado por cem (100) para obtenção do IT. Caso expresso em milirem/hora, é multiplicado por um (1).

Exemplo:

Dose a um metro da embalagem $=0,002 \mathrm{mSv} / \mathrm{h}$ ou $2 \mu \mathrm{Sv} / \mathrm{h}$.

Multiplicação: $0,002 \times 100=2$.

Logo o IT daquele embalado é igual a 2.

Em alguns casos, como para minérios e concentrados de urânio e tório e para materiais físseis, o IT é calculado de forma diferente, mas segue o mesmo princípio: limitar a exposição a 1 metro do embalado.

Assim, os embalados ou conjuntos de embalados podem atingir diferentes índices de transporte, mas o número é limitado em norma e, portanto, controla a quantidade de radiação a que o ambiente, pessoas e outros bens podem estar expostos durante a operação normal de transporte.

No Brasil, o transporte de materiais radioativos inclui, basicamente, todos os modais: terrestre (rodoviário e ferroviário), aéreo e marítimo. O transporte, na maioria das vezes, é contratado pelo expedidor do material radioativo ou pelo comprador do material, ou seja, o transporte é realizado por empresas transportadoras, e não pela empresa que o fabrica ou o utiliza. Há algumas exceções a este caso, que ocorrem com os órgãos governamentais e suas dependências e, em parte, por empresas mineradoras e de produção de energia nuclear, que possuem sistemas de transporte próprio. Em ambos os casos, há a necessidade de licenciamento para a operação de transporte da classe 7 junto aos órgãos reguladores descritos na Tabela 5 , página 45 deste documento.

De acordo com as entrevistas realizadas, a própria transportadora, por vezes, se utiliza dos serviços de outra empresa de transportes com modal diferente. É o caso do transporte de radiofármacos, no qual as empresas que possuem unidades de transporte terrestre contratam empresas de transporte aéreo para levar o material a outras regiões do país. Isso também ocorre na importação de insumos radioativos não produzidos no Brasil, como o Molibidênio-99, utilizado na produção de geradores de Tecnécio-99, que é importado de outros países e chega por via aérea e, posteriormente, 
segue para o transporte terrestre até a unidade compradora. No modal marítimo, podese citar os procedimentos de cabotagem, que é o transporte ao longo da costa nacional, e transporte internacional. Uma empresa, também com unidades de transporte terrestre, contrata uma empresa marítima para realizar o trajeto do material radioativo pela costa brasileira ou para outros países.

O Gráfico 1 mostra os modais utilizados por transportadoras entrevistadas durante este trabalho.

\section{Gráfico 1 - Modais de transporte utilizados}

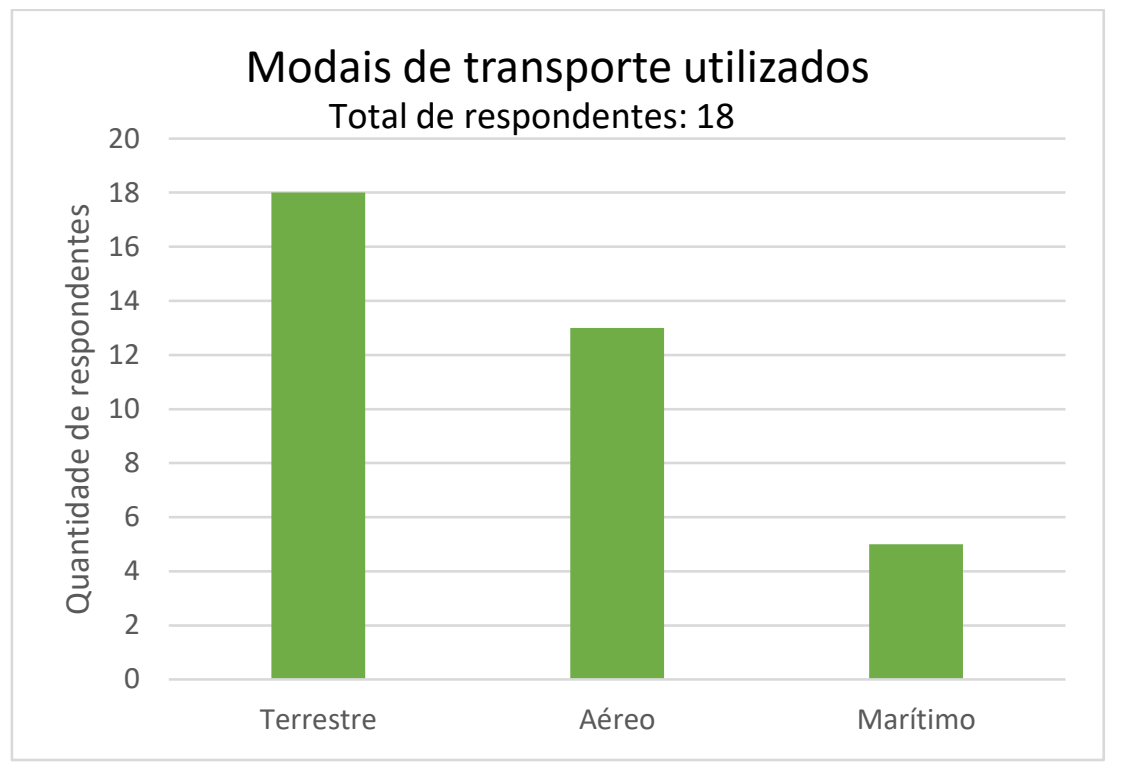

Fonte: autor da dissertação.

Todos os respondentes utilizam o modal terrestre (100\%). Aproximadamente $72 \%$ utiliza o transporte aéreo e aproximadamente $28 \%$ utiliza o modal marítimo. Os respondentes são transportadores de materiais radioativos dos modais terrestre e aéreo, além de expedidores de material radioativo que possuem transporte próprio. Cada participante corresponde, idealmente, a uma instituição ou empresa, totalizando 18 participantes.

Acrescenta-se que a maioria das empresas é licenciada ou responsável, diretamente, por um único modal. Ou seja, são unimodais. Uma empresa com unidades de transporte terrestre não possui aeronaves ou embarcações, as empresas aéreas não possuem embarcações ou unidades terrestres, e as empresas marítimas limitam- 
se ao transporte aquaviário. Assim, os meios de transportes estão interligados e poucas operações dependerão de um único modal ou empresa responsável.

Além destes conhecimentos, é importante ter um espírito de pesquisador com a finalidade de melhorar cada vez mais as atividades de proteção radiológica e do transporte de material radioativo em segurança. 


\section{MATERIAIS E MÉTODOS}

Este trabalho foi realizado a partir de revisões bibliográficas e levantamento de dados através de questionários e entrevistas [14]. Por se tratar de um tema muito prático, o conteúdo de revisão bibliográfica é formado por normas regulatórias, relatórios de encontros, reuniões e debates internacionais e nacionais a respeito do assunto, publicações e atas realizados por empresas do ramo e, em sua minoria, trabalhos acadêmicos que abrangem parcialmente o tema abordado.

O levantamento de informações sobre as recusas e demoras ocorridos no país foi obtido, em sua maioria, por relatos prestados por empresas de transporte de material radioativo, expedidores e destinatários envolvidos no processo de transporte e membros de entidades nacionais regulatórias, por meio de questionário online, questionário presencial ou entrevista presencial. Para evitar quaisquer tipos de prejuízos aos participantes, todos os dados foram colhidos de forma anônima, assim, os prestadores das informações aqui contidas não podem ser diretamente identificados. O termo de consentimento livre e esclarecido (TCLE), aplicado a todos os participantes, encontra-se no APÊNDICE A deste trabalho. Os dados de entrevistas e questionários foram coletados entre setembro de 2017 e abril de 2018, havendo participação total de 129 respondentes.

\subsection{Aplicação de questionários e entrevistas}

Os entrevistados foram divididos em dois grupos, denominados Grupo Específico 1 e Grupo Específico 2. O Grupo Específico 1 é composto por pessoas envolvidas diretamente no transporte de material radioativo, podendo abranger funcionários de uma empresa de transporte de material radioativo, membros de entidades regulatórias participantes e ativos no processo, funcionários de uma unidade expedidora de material radioativo ou unidade a que o material é destinado. O Grupo Específico 2 é composto por pessoas que participam do transporte de produtos perigosos, exceto material radioativo, abrangendo funcionários de transportadoras de cargas perigosas que não atuem com o transporte da classe 7 . 
Aos dois grupos, foi aplicado um questionário, denominado Questionário 1 (APÊNDICE B), para avaliar a percepção de risco do transporte de materiais radioativos. Por acreditar que o medo de radiação é um dos fatores que contribuem para ocorrência de recusas e demoras no transporte de materiais radioativos, o questionário foi aplicado aos diferentes grupos a fim de comparar esta percepção.

Sabe-se que o transporte de material perigoso no país exige a formação dos profissionais nele envolvidos. A normatização que regulamenta esta formação dependerá, principalmente, do modal. No modal terrestre, por exemplo, encontra-se a normatização do Conselho Nacional de Trânsito (CONTRAN) no 168 de 2004, com exigência do curso para os motoristas, conhecido como curso de movimentação e operação de produtos perigosos (MOPP) especificada no artigo 145 do Código Brasileiro de Trânsito (CTB) [15, 16].

No modal aéreo, a Agência Nacional de Aviação Civil, ANAC, estabelece pelo Regulamento Brasileiro de Aviação Civil (RBAC) № 175 de 2018 [17] que:

O treinamento de transporte aéreo de artigos perigosos deve ser realizado ou verificado no momento de empregar uma pessoa em posição que envolva o transporte de carga aérea. $O$ treinamento periódico deve ser realizado, pelo menos, uma vez a cada 24 (vinte e quatro) meses.

Em seu sítio, a ANAC orienta que este treinamento deve ser realizado por qualquer pessoa que esteja envolvida com a carga aérea, incluindo-se funcionários de operadores aéreos, operadores de terminais de carga, empresas expedidoras de artigos perigosos como carga aérea, agências de carga aérea e empresas prestadoras de serviços auxiliares ao transporte aéreo, nacionais ou estrangeiras, envolvidas com expedição, transporte, manuseio, movimentação e armazenagem de carga aérea, bem como aquelas envolvidas com a segurança e inspeção de passageiros e bagagens. $O$ treinamento é oferecido por instituições credenciadas junto à ANAC [18].

Também o código marítimo internacional para cargas perigosas (International maritime dangerous good code - IMDG code) estabelece que os envolvidos no transporte de cargas perigosas por via marítima devem ser treinados de acordo com a função a ser exercida. O código é seguido pela Marinha do Brasil, que segue o mesmo preceito e procura adequar-se às suas exigências [19]. 
Os cursos, de maneira geral, não se diferem entre as classes de produtos perigosos e o mesmo curso capacita para todo tipo de transporte de produtos perigosos em seu respectivo modal. A exemplo dos modais aéreo e marítimo, o treinamento é adequado de acordo com o cargo do funcionário, mas também capacita para todos os tipos de produtos perigosos. Por isso, comparou-se a percepção de risco entre as pessoas que receberam a mesma base de treinamento exigida na legislação, com diferença somente na execução prática do trabalho, que, neste caso, representa a classe a ser transportada. Teoricamente, por estarem igualmente preparados para 0 transporte de todas as classes de produtos perigosos, a percepção de risco não deveria diferir consideravelmente entre os grupos. Porém, durante a execução do trabalho, notou-se que os transportadores do material radioativo realizavam e demandavam de treinamento extra àquele exigido em legislação. Este treinamento era realizado, principalmente, pela própria empresa transportadora ou com ajuda de membros dos órgãos regulatórios, como a Comissão Nacional de Energia Nuclear. Logo, se há necessidade deste tipo de abordagem, temos o indicativo que a formação exigida em regulamentação nacional não é suficiente para a obtenção de uma formação sólida e capaz de qualificar um motorista ou operador para o transporte de materiais radioativos sem que problemas de recusa e demora como os que vem ocorrendo sejam evitados ou minimizados. A primeira base de comparação entre os grupos e análise, assim, é a de percepção de risco, avaliando o medo de radiação ionizante durante a operação de transporte (Questionário 1), que segue o esquema a seguir descrito. Outra análise realizada, é a da grade curricular dos cursos exigidos pela legislação, verificando se esta é suficiente ou adequada no caso do transporte de materiais radioativos.

O Questionário 1 foi formulado por meio de indicadores (questões) que mensuram um fator qualitativo (o medo) [14]. O medo de radiação é um item abstrato, logo, há a necessidade de se criar um sistema para quantifica-lo ou mensurá-lo. Cada fator corresponde a um aspecto que indica a presença do medo de radiação, isto é, como o medo da radiação se manifesta no caso do transporte de material radioativo. Os fatores foram escolhidos com base nas primeiras entrevistas pessoais realizadas sem o questionário e nos relatos internacionais e nacionais sobre o assunto.

Na figura 1, é fornecido o esquema do Questionário 1 e seus indicadores. A percepção de medo, no caso dos transportes, especificamente, foi subdividida em três fatores, sendo eles: 
a) Medo da ocorrência de acidentes envolvendo material radioativo, com a percepção de que este tipo de acidente seria mais perigoso que os demais acidentes ocorridos no transporte;

b) Medo de problemas de saúde causados pela radiação ionizante, principalmente impulsionado pelos medos das bombas atômicas e acidentes nucleares;

c) Medo de prejuízo à imagem social da empresa ou seu relacionamento com a sociedade, o que poderia reduzir a oferta deste tipo serviço no mercado.

\section{Figura 1 - Esquema do Questionário 1 e seus indicadores}

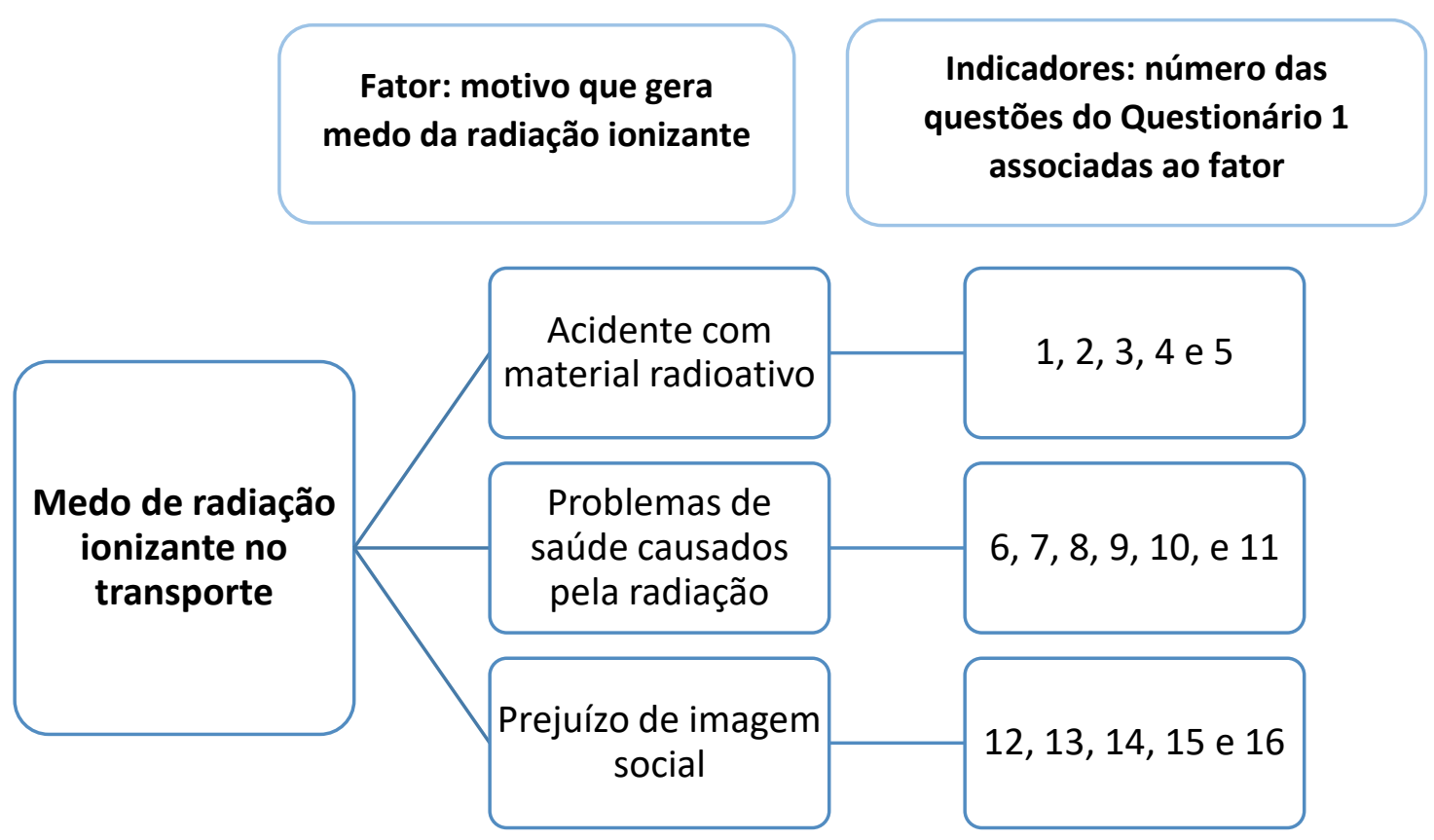

Fonte: autor da dissertação.

A mensuração dos três fatores ocorreu por meio do Questionário 1, que contém indagações a respeito de cada um, com as quais os participantes expunham seu grau de concordância de 1 a 7 . O nível 1 foi reservado para a discordância total, enquanto o nível 7 para a total concordância com a afirmativa em questão. Indica-se que cada fator seja mensurado por pelo menos 3 indicadores (indagações) para que 0 resultado seja confiável estatisticamente e evite o enviesamento, sendo ideal a medição do fator conter de 4 a 7 indicadores [14]. Os itens (indagações) de 1 a 16 compõe os indicadores para cada fator, como dispostos na Figura 1. 
Alguns participantes do Grupo Específico 1 responderam, além do Questionário 1, a uma série de 8 questões denominado Questionário 2 (APÊNDICE C). Estas questões visam avaliar:

a) A frequência de eventos de recusas e demoras sofridos pela empresa no último ano e nos últimos 5 anos;

b) O modal que apresenta, na opinião das empresas, a maior quantidade de eventos de recusa e/ou demora;

c) Os problemas enfrentados pelas transportadoras durante uma recusa ou demora,

d) Prejuízos financeiros e outras perdas sofridos por causa das recusas e demora.

Por se tratarem de perguntas que correspondem a informações competentes para os cargos específicos na empresa, nem todos os participantes do Grupo Específico 1 estavam aptos a responder. Assim, o Questionário 2 foi destinado aos participantes que se denominavam representantes de uma empresa de transporte de material radioativo, representantes de uma unidade expedidora de materiais radioativos e representantes de unidades a que o material radioativo é destinado.

\subsection{Software de análise e testes aplicados}

O programa utilizado para a análise de dados chama-se "R" (The $R$ Foundation) versão 3.1.2 64 bits. Trata-se de um software gratuito que permite realizar análises de dados quantitativos.

A primeira porção de testes aplicados serve para validar a amostra e o questionário em si, avaliando se os dados são confiáveis e mensuram corretamente o que foi planejado. A segunda porção de testes serviu para analisar os resultados obtidos de forma quantitativa. Os testes aplicados são descritos a seguir.

\subsubsection{Validação da amostra}

Um dos parâmetros de qualidade na pesquisa é a seleção e o controle corretos da amostra que, neste caso, são os respondentes [14]. Para o Questionário 1 , os Grupos 1 e 2 receberam técnicas de amostragem diferentes. O Grupo 1 é 
sabidamente finito, ou seja, há uma quantidade finita de transportadores de material radioativo, apesar de não se conhecer o total deles, que seria o limite da população. Assim, em estatística tratamos este grupo com os critérios de uma população infinita. A amostra possui 30 participantes, englobando 13 instituições distintas com atuação e sede em vários estados brasileiros. Algumas participações foram tomadas durante as reuniões do Comitê Nacional, enquanto outras foram tomadas eletronicamente ou presencialmente em outras datas e horários. A heterogenia do grupo em relação aos seus representantes e localidades garante a esta amostra confiabilidade na representação da população do Grupo 1 no tema abordado. Além disso, o processo de aquisição dos dados e o anonimato dos participantes torna impossível a listagem ou contagem de cada elemento da amostra dentro da população. Cada elemento selecionado vem da mesma população e cada elemento foi selecionado de forma independente, cumprindo assim os requisitos de uma amostra aleatória para populações infinitas [20].

Já o Grupo 2 possui uma população muito grande, sendo tratada em estatística como população infinita, na qual o limite não é conhecido. Nesta população foi realizada a amostragem estratificada, em que uma amostra aleatória é dividida em extratos homogêneos que se unem posteriormente. A estratificação permite um controle melhor dos indivíduos participantes de acordo com sua característica (extrato), trazendo mais confiabilidade para a amostra e tornando-se mais adequada que a amostragem aleatória simples para amostras pequenas [20].

No Grupo 2, os extratos selecionados foram: transportadores de combustível, transportadores de explosivos, transportadores de gás liquefeito de petróleo e transportadores de todos os tipos de produtos perigosos. A este último extrato pertenciam, por exemplo, motorista habilitados por sua empresa em todas as categorias de produtos perigosos e funcionários de empresas aéreas envolvidos no transporte de produtos perigosos em geral. O questionário foi aplicado em locais, dias e horários diferentes para cada um dos extratos. Os dados foram coletados em 3 cidades do estado de São Paulo, totalizando 99 participantes. Cada elemento desta amostra vem da mesma população e cada elemento foi selecionado de forma independente, cumprindo as condições da amostragem aleatória para populações infinitas [20]. 
Os participantes que não responderam ao questionário 1 completamente tiveram sua participação eliminada. O procedimento reduziu de 137 para 129 o número total de participantes. Assim, o questionário não foi analisado com dados faltantes nem recebeu preenchimento aleatório para os dados inexistentes [14].

Outra verificação foi a da presença de respondentes enviesados, mais conhecidos em estatística como outliers. São participantes que respondem o questionário de forma aleatória, sem prestar atenção ao conteúdo das perguntas, podendo assinalar uma mesma opção na escala para todas as indagações ou fornecer respostas que diferem muito das do grupo, o que indica que o participante tem grande probabilidade de não fazer parte da população amostrada. Esses participantes fazem com que a média seja alterada, especialmente em amostras pequenas, resultando em análises errôneas. O teste para outliers não encontrou participantes nesta situação [14].

\subsubsection{Validação do questionário}

Os testes de validação do questionário asseguram que este mensura corretamente o que foi proposto e que os resultados obtidos são confiáveis [14, 20]. Os testes aplicados foram: confiabilidade de escala, análise fatorial exploratória, análise de consistência interna e análise de correlação.

Um pré-teste para verificar se o questionário estava claro e compreensível aos leitores foi aplicado a 15 pessoas que eram envolvidas ou não com o transporte de materiais radioativos. Pequenas alterações foram feitas no vocabulário, porém o conteúdo e a quantidade de perguntas permaneceram inalterados.

O teste de confiabilidade de escala, para avaliar se a escala de medição utilizada é adequada para mensurar a variáveis (marcação de concordância de 1 a 7), obteve valores de alpha (medidor do teste) acima de 0.87 em todos os itens, sendo que o indicado é que se obtenha valores entre 0,7 e 0,9, o que torna a escala confiável [14].

O medo de radiação durante o transporte da classe 7 representa a variável estudada no Questionário 1, dividida em três fatores e mensurada por 16 itens, como explicado anteriormente. $O$ teste aplicado para verificar a validade dos itens e dos fatores foi a análise fatorial exploratória. Este teste verifica se a quantidade de fatores é satisfatória para medir a variável e se os itens foram agrupados corretamente dentro 
dos fatores. Basicamente, verifica se os itens e fatores são válidos (verdadeiros) para mensurar a variável da forma que foram dispostos.

Como existem dois grupos de pesquisa, o teste foi aplicado a cada grupo separadamente. A significância, mais conhecida como valor $p(p$ value) do teste foi estabelecida em $5 \%$, valor sugerido em literatura como ótimo [14, 20]. Para agrupar os itens em um único fator, de acordo com o teste, a correlação deveria ser maior que $50 \%$ (0.5). Estatisticamente, uma correlação fraca está abaixo de 0.3 , uma correlação aceitável está entre 0.3 e 0.7 e uma correlação forte acima de 0.7 . Os resultados mostram qual foi o agrupamento de itens sugerido pelo teste de análise fatorial exploratória. Assim, indica, estatisticamente e de acordo com as respostas adquiridas, quais itens mensuram um mesmo fator. Isto acontece porque, se um item varia conjuntamente e está correlacionado com outro, probabilisticamente, eles mensuram a mesma coisa (fator) [14]. Na realidade deste questionário, quer dizer que um conjunto de itens mensura um mesmo aspecto do medo de radiação durante os transportes. Os resultados encontram-se na Tabela 1.

Tabela 1 - Análise fatorial exploratória para validação do questionário

\section{Análise fatorial exploratória}

\begin{tabular}{|c|c|c|}
\hline Parâmetros & Grupo 1 & Grupo 2 \\
\hline Extração de fatores & 3 fatores são suficientes & 3 fatores são suficientes \\
\hline Significância & 0.017 & $<0.01$ \\
\hline Agrupamento por & Itens 1, 2, 3, 6, 7, 8, 9, & Itens 3, 6, 7, 8, 10 e 11 \\
correlação para o fator 1 & 10 e 11 & \\
\hline $\begin{array}{c}\text { Agrupamento por } \\
\text { correlação para o fator 2 }\end{array}$ & Item 4 & Itens 1 e 2 \\
\hline $\begin{array}{c}\text { Agrupamento por } \\
\text { correlação para o fator 3 }\end{array}$ & Itens 12, 13 e 14, 15 e & Itens 12, 13 e 14, 15 e \\
\hline Fo & 16 & 16 \\
\hline
\end{tabular}

Fonte: autor da dissertação.

O item 5 não apresentou correlação aceitável com nenhum fator em ambos os grupos. Os itens 4 e 9 não apresentaram correlação aceitável somente no Grupo 2.

De acordo com os resultados, os grupos se comportam de maneiras diferentes em sua reação aos itens. Percebe-se que os itens 1 e 2 são associados a 
fatores distintos entre os grupos. Isto não quer dizer que o questionário não é válido, mas que os itens são percebidos e interpretados de formas diferentes e, por isso, mensuram coisas diferentes em cada grupo. Para adequar a esta situação, decidiu-se eliminar os fatores e itens discrepantes, mantendo em análise somente os itens que eram interpretados da mesma maneira por ambos os grupos, que são a maioria. Logo, o modelo do questionário de análise corrigido é mostrado na Figura 2, que compõe o conjunto de dados a ser analisado.

Figura 2 - Questionário 1 adaptado após análise fatorial

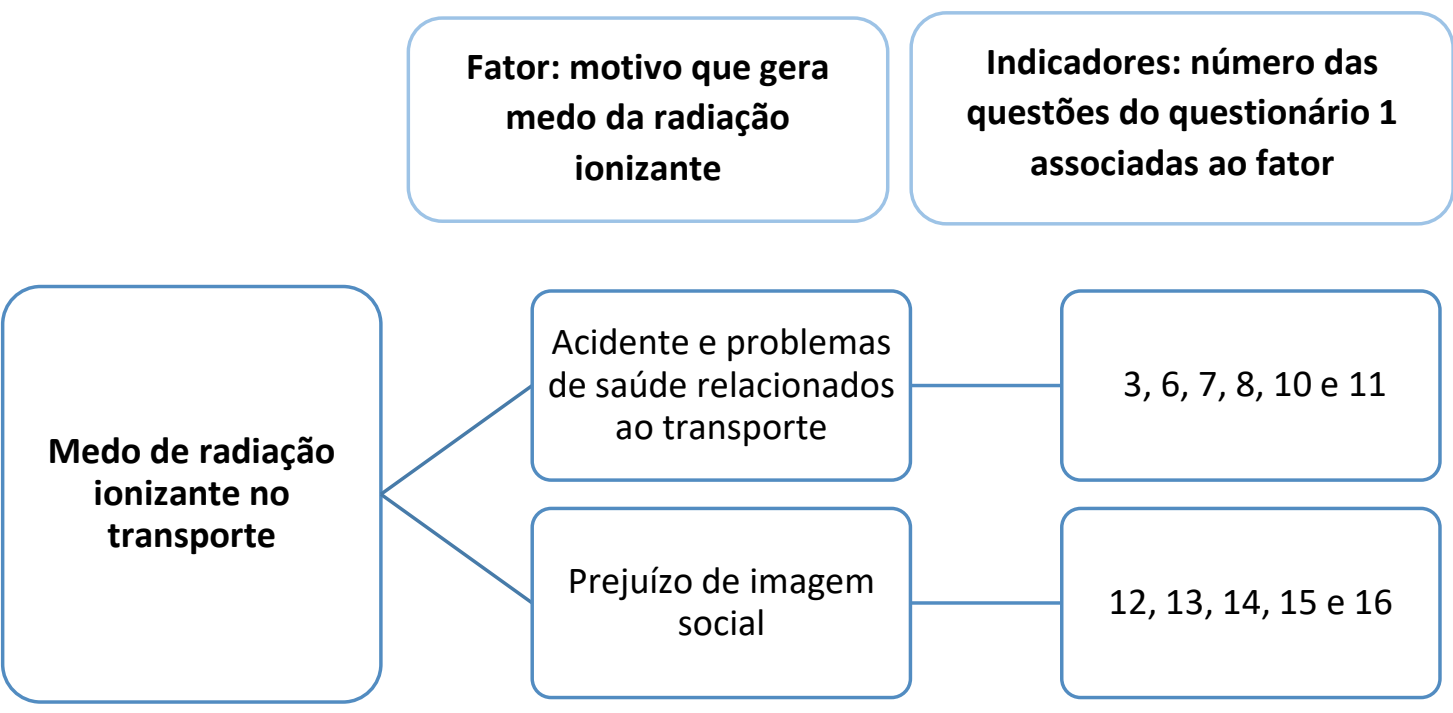

Fonte: autor da dissertação.

Neste modelo, que se adequa à percepção dos grupos, a ocorrência de acidentes e os problemas relacionados a saúde representam um único fator do medo, estando correlacionados e, portanto, agrupados em um único fator. $O$ fator de prejuízo de imagem social não foi alterado e permanece de acordo com o idealizado no esquema da Figura 1, passando pelo teste sem modificações necessárias. Um novo teste de análise fatorial exploratória foi aplicado a ambos os grupos com os itens ajustados de acordo com a Figura 2. Os resultados são apresentados na Tabela 2.

O aumento no valor $p$ para o Grupo 1 pode ser explicado pelo tamanho da amostra, que é menor que no Grupo 2. Ainda assim, encontra-se dentro do limite 
aceitável estabelecido $(<0,05)$. Todas as correlações foram acima de $0.56 \mathrm{em}$ seu respectivo fator, demonstrado correlação aceitável ou forte para mensuração.

A análise de consistência interna verifica a correlação entre os itens de cada fator com utilização de um valor chamado alfa de Cronbach. Em estatística, se os itens medem um mesmo fator devem estar correlacionados entre si. Logo, este teste serviu para confirmar a disposição dos itens obtida pela análise fatorial exploratória, atestando que são correlacionados e estão mensurando a mesma coisa. A Tabela 3 mostra os valores de alfa de Cronbach obtidos no teste realizado. Idealmente, os valores devem estar entre 0.7 e 1.0 para que a correlação seja confiável, o que foi obtido no questionário [14].

Tabela 2 - Análise fatorial exploratória para validação do questionário adaptado Análise fatorial exploratória para o questionário adaptado

\begin{tabular}{|c|c|c|}
\hline Parâmetros & Grupo 1 & Grupo 2 \\
\hline Extração de fatores & 2 fatores são suficientes & 2 fatores são suficientes \\
\hline Significância & 0.026 & $<0.01$ \\
\hline $\begin{array}{c}\text { Agrupamento por } \\
\text { correlação para o fator } 1\end{array}$ & Itens 3, 6, 7, 8, 10 e 11 & Itens 3, 6, 7, 8, 10 e 11 \\
\hline $\begin{array}{c}\text { Agrupamento por } \\
\text { correlação para o fator 2 }\end{array}$ & Itens 12, 13 e 14, 15 e & Itens 12, 13 e 14, 15 e \\
\hline Fonte: autor da dissertação. & 16 & 16 \\
\hline
\end{tabular}

Tabela 3 - Valores de consistência interna por alfa de Cronbach

\begin{tabular}{c|c|c|}
\hline $\begin{array}{c}\text { Fator analisado / Grupo } \\
\text { de pesquisa }\end{array}$ & Grupo 1 & Grupo 2 \\
\hline Fator 1 & $0.76(p=0.012)$ & $0.82(p<0.01)$ \\
\hline Fator 2 & $0.87(p<0.01)$ & $0.89(p<0.01)$ \\
\hline
\end{tabular}

Fonte: autor da dissertação.

O teste de correlação entre os fatores 1 (acidentes e problemas de saúde) e 2 (prejuízo a imagem social) obteve o valor de 0.24 (valor $p$ 0.012) no Grupo 1 e 0.25 (valor $p$ 0.012) no Grupo 2, o que representa uma correlação fraca e praticamente inexistente [14]. Assim, não há correlação entre estes e se demonstram fatores independentes, descartando a opção de causalidade. Ou seja, o medo de acidentes e 
problemas de saúde não possui relação de causalidade com o medo de prejuízo a imagem social.

\subsubsection{Análise quantitativa do questionário}

Os dois fatores de análise foram compilados com uma equação de média simples. Assim, as equações para resumo dos itens em um único fator foram:

Fator 1 - acidentes e problemas de saúde:

$$
(X 3+X 6+X 7+X 8+X 10+X 11) / 6
$$

Fator 2 - prejuízo a imagem social:

$$
(X 12+X 13+X 14+X 15+X 16) / 5
$$

Como o questionário possui uma escala de 1 a 7 , estes também representam os valores máximos que podem ser obtidos na média de respostas. De acordo com a formulação das perguntas do questionário 1 (APÊNDICE B), quanto maior o valor assinalado na escala, maior a presença de medo na questão relacionada. Da mesma forma, médias maiores nos fatores indicarão mais presença de medo.

Os dados obtidos foram resumidos em forma de média, histogramas de frequência e estudo de quartis em ambos os grupos. Como não houve correlação (testes de correlação <0.26 em ambos os grupos e $p$ valor $<0.05$ ) entre os dois fatores, outras análises como a regressão linear e o gráfico de dispersão não são adequados neste caso. Os resultados obtidos são apresentados e discutidos no capítulo 7.

O questionário 2 não recebeu os testes acima por ter sido formulado para calcular um conjunto de varáveis quantificáveis, como a frequência de eventos de recusa e demora. Assim, a demonstração dos resultados foi realizada em forma de gráficos e tabelas que demonstram as respostas diretas de cada um dos participantes. Os gráficos e tabelas encontram-se ao longo da dissertação, dispostos conforme o assunto que abrangem é abordado. Além disso, a amostra do Questionário 2 é menor que a amostra do questionário 1 , fazendo com que os testes quantitativos não sejam adequados por causa do tamanho da amostra [14]. Ainda assim, os dados expostos são confiáveis por não terem sido submetidos a testes quantitativos que modulam ou os altera de alguma forma, e refletem a opinião de um grupo selecionado de participantes. 


\subsection{Adequação da metodologia aos objetivos propostos}

Como dito anteriormente, pouco se encontra na literatura científica sobre o problema tratado neste trabalho. Assim, as entrevistas realizadas com os envolvidos no transporte de materiais radioativos contribuem para alcançar os objetivos 2, 3 e 4 citados no subcapítulo 1.3. Também contribui para o alcance destes objetivos o questionário 2, que fornece um sistema de quantificação que permite avaliar a frequência de ocorrência dos problemas e estimar sua magnitude em prejuízos sofridos. Também coleta, de forma mais rápida e direta que em uma entrevista pessoal, informações importantes para propor novas soluções, que é o objetivo 5 deste trabalho. Estas informações são, por exemplo, em qual modal há maior ocorrência de recusas e atrasos e quais são os problemas enfrentados.

O questionário 1, mais especificamente, dedica-se ao cumprimento do objetivo número 6 . Ele fornece um levantamento empírico sobre a percepção de medo por parte dos indivíduos que trabalham diretamente com a classe $7 \mathrm{e}$, para haver base de comparação, a confronta com a percepção de outros transportadores de produtos perigosos. Isto permite demonstrar, por meio de quantificação, o medo da radiação ionizante descrito em alguns relatórios do Comitê Nacional e avaliar sua extensão. Para esta avaliação, utilizou-se os métodos descritos no subcapítulo 3.2 deste trabalho, comum a pesquisas que procuram atribuir a fatores qualitativos, como o medo de radiação, uma abordagem quantitativa. 


\section{CENÁRIO DE RECUSAS E DEMORAS NO BRASIL}

A primeira abordagem documentada sobre as recusas e demoras no transporte de material radioativo ocorreu em 2003, durante a conferência do OIEA, em Vienna. Expôs-se que os relatos de recusas e demoras nos transportes de materiais radioativos estavam aumentando gradativamente. Apesar do ótimo trabalho relativo à segurança do transporte dos materiais da classe 7 , a quantidade de empresas que realizavam esse transporte estava diminuindo, enquanto a burocracia para a atividade estava aumentando [1]. Em 2008, durante uma oficina realizada na China, países da Ásia e do Pacífico confirmaram a presença do problema e, inclusive, seu crescimento [21].

Na modalidade marítima, por exemplo, ressalta-se que poucas empresas realizam o transporte da classe 7. Em algumas rotas, como aquela da Europa Ocidental para a Ásia oriental, somente uma a cada dez empresas prestava este tipo de serviço em 2003, limitando as opções de transporte. Deste modo, dependendo da disponibilidade das embarcações, o transporte só poderia estar disponível dentro de 3 a 6 meses. Esta indisponibilidade, muitas vezes, decorria das massivas normas, pois há um risco maior de as autoridades portuárias recusarem o desembarque de cargas contendo o material radioativo, o que faria a empresa perder outros negócios e produtos que estão no mesmo navio [1].

Os encontros ocorridos internacionalmente e promovidos pelo OIEA não listam casos de recusas ou demoras, propriamente. Mas reportam a situação mundial e os motivos que causam o problema $[1,21,22,23,24]$.

No Brasil, o Comitê Nacional, presidido atualmente por membros da CNEN, reúne transportadores, expedidores, membros de órgãos regulatórios e outros interessados no transporte de materiais radioativos a fim estabelecer ações que extingam ou minimizem as demoras e recusas no país. $O$ trabalho realizado pelo grupo é notório e obteve bons resultados até o momento. Algumas das ações tomadas pelo Comitê Nacional serão abordadas ao longo do trabalho. A Tabela 4 mostra, 
quantitativamente, os encontros já realizados e os participantes envolvidos. Os dados foram retirados das atas das reuniões e das listas de participantes a que se teve acesso.

Tabela 4 - Dados quantitativos dos encontros do Comitê Nacional

\section{Encontros do Comitê Brasileiro de Recusas e Demoras no Transporte de Materiais Radioativos e Outros Materiais Nucleares}

\begin{tabular}{l|c|}
\hline Número de encontros (até maio de 2018) & 11 \\
\hline Média de intervalo de tempo entre os encontros & 10 meses \\
\hline Quantidade de entidades públicas participantes & 19 \\
\hline Quantidade de empresas privadas participantes & 41 \\
\hline Fonte: autor da dissertação.
\end{tabular}

Fonte: autor da dissertação.

Durante as entrevistas, alguns expedidores e membros de órgãos regulatórios relataram uma melhora significativa nos últimos anos. Porém, para alguns transportadores, o problema persiste, principalmente nos modais marítimo e aéreo. Como será descrito no subcapítulo 4.3.1 deste trabalho, o fornecimento dos relatos de recusa e demora e o acesso a eles também é um problema. Portanto, decidiu-se estimar a quantidade de eventos de recusa e demora com que os expedidores e transportadores tem lidado nos últimos 12 meses e nos últimos 5 anos. Os dados foram coletados entre setembro de 2017 e abril de 2018 e estão demonstrados nos gráficos 2 e 3 .

\section{Gráfico 2 - Eventos de recusas e demoras em 12 meses}

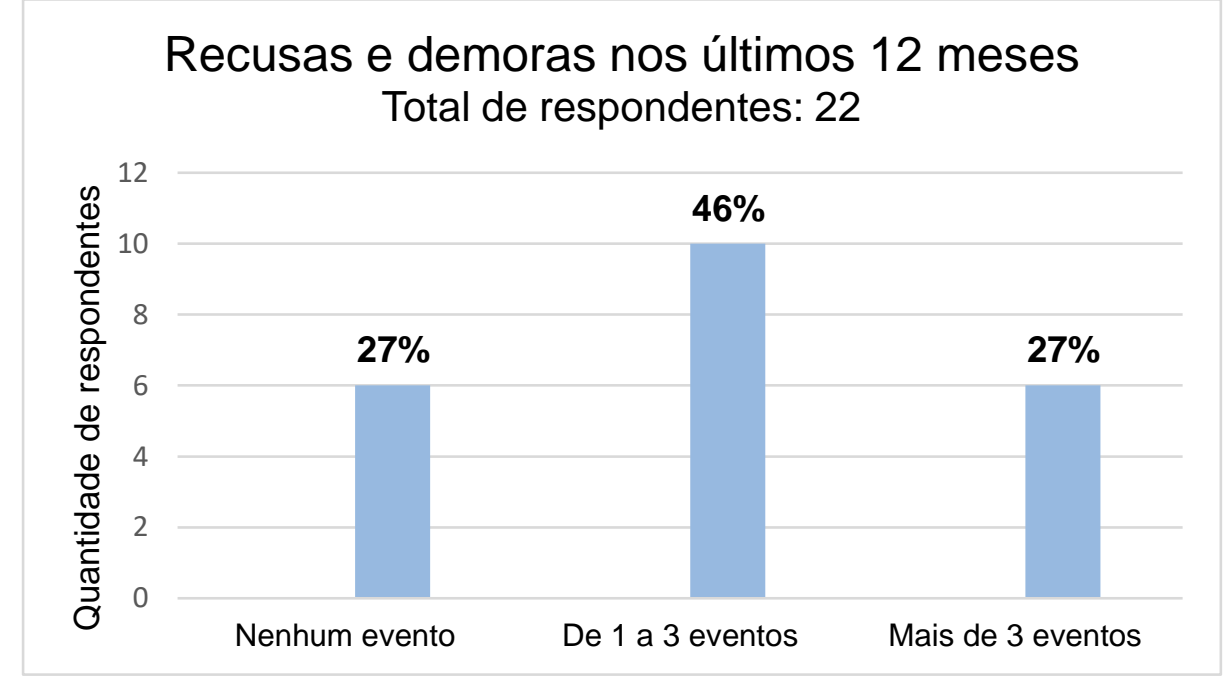

Fonte: Autor da dissertação. 


\section{Gráfico 3 - Eventos de recusas e demoras em 5 anos}

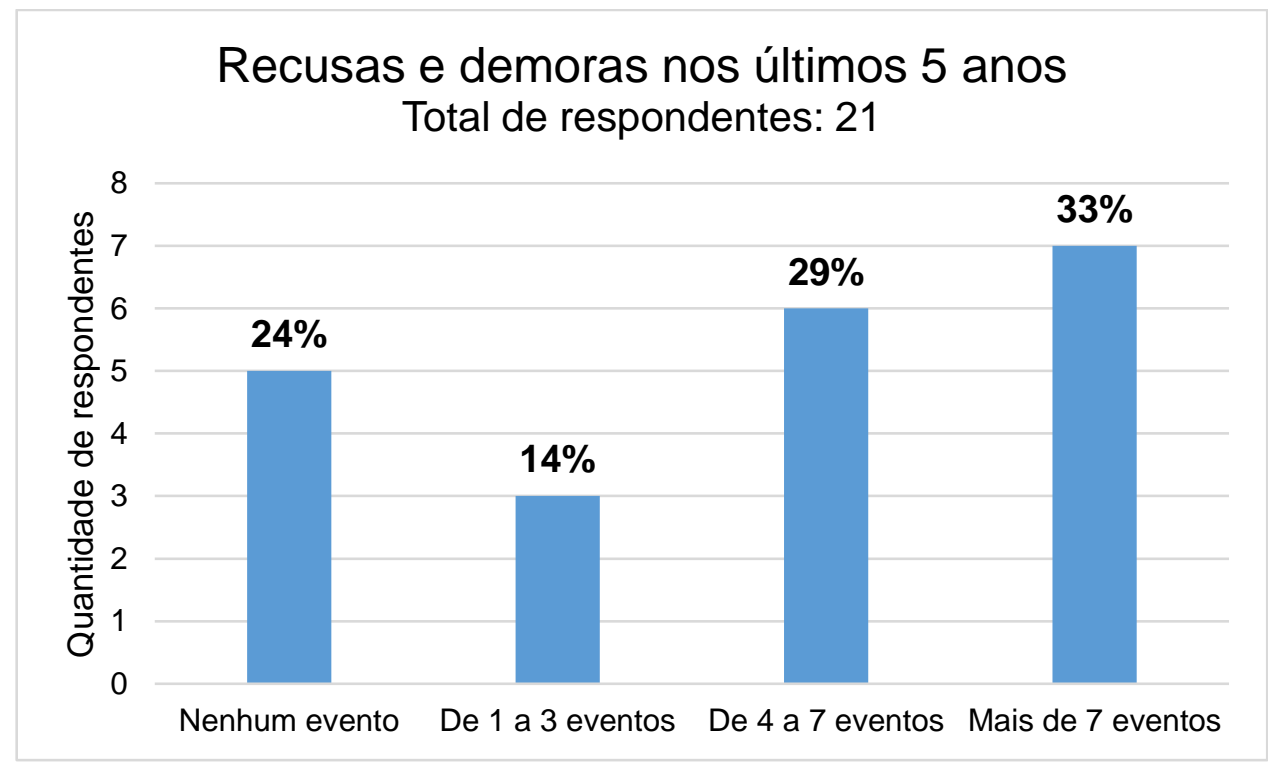

Fonte: autor da dissertação.

As quantidades indicadas foram baseadas nas informações encontradas nos relatórios do Comitê Nacional. No segundo encontro, em 2010, por exemplo, foram relatados 3 eventos para um período de 1 ano. Assim, o intervalo da escala utilizado na entrevista foi ajustado para o número médio de ocorrências descritas nos relatórios dos encontros do Comitê Nacional [25].

Durante as entrevistas pessoais, especialmente com os transportadores, percebeu-se que os eventos ainda ocorrem. Porém, a tratativa parece estar mais rápida e efetiva, fazendo com que o problema seja resolvido rapidamente e, assim, não seja relatado ou contabilizado. Ou, se contabilizado, não é divulgado. Isto é embasado pelos gráficos acima, nos quais 6 instituições tiveram 3 ou mais eventos de recusa e demora em um ano, e 7 instituições tiveram 7 ou mais eventos em 5 anos.

As ações do Comitê Nacional estão voltadas para problemas novos, ainda não tratados, ou para os quais a tratativa não possui um caminho bem estabelecido. Isto é considerado razoável, já que a erradicação de um ou outro tipo de ocorrência pode não ser possível, principalmente quando depende de fatores humanos que não estão ao alcance da influência do Comitê Nacional. A discussão de tratativas para os problemas aqui apresentados será fornecida nos capítulos 8 e 9 deste trabalho. 


\subsection{Motivos que acarretam recusas ou demoras no transporte de materiais radioativos}

Para o Comitê Nacional, há mais de um motivo que acarreta o problema de recusas e demoras no transporte de materiais radioativos [7]. Foram descritos no primeiro encontro, em 2010, seis itens, que concordam com os apresentados pelo OIEA em 2003. São eles:

1. Apreensão e percepção equivocada do risco por parte de transportadores, armadores (que promovem o frete de embarcações comerciais), companhias aéreas e marítimas e membros do público;

2. Falta de informação sobre a segurança do transporte;

3. Preocupação quanto ao possível custo elevado de treinamento para profissionais envolvidos em operações de transporte;

4. Multiplicidade excessiva e, às vezes, contraditória da regulamentação sobre os materiais radioativos e seu transporte;

5. Interpretação incorreta da regulamentação;

6. Aspectos econômicos x exigências para a execução do transporte.

A Agência Nacional de Transportes Terrestres (ANTT) realizou em 2010 uma pesquisa com empresas de transporte de produtos perigosos a fim de avaliar o motivo pelo qual não estão dispostas a trabalhar com o material radioativo. Os resultados foram apresentados durante o segundo encontro do Comitê Nacional [25]. Os motivos alegados conseguiram ser resumidos em 3 pela ANTT, sendo eles:

- A percepção que o material radioativo causa mais danos que outros produtos perigosos;

- A carência de conhecimento e treinamento sobre a legislação e a regulamentação de segurança;

- Os elevados custos de contratação e de seguro e serviços de atendimento a situações de emergência.

Com base nestas informações e nas entrevistas, perguntou-se às empresas quais situações que causam recusa ou demora já haviam enfrentado. Houveram 15 respondentes e o resultado é mostrado no gráfico 4. 


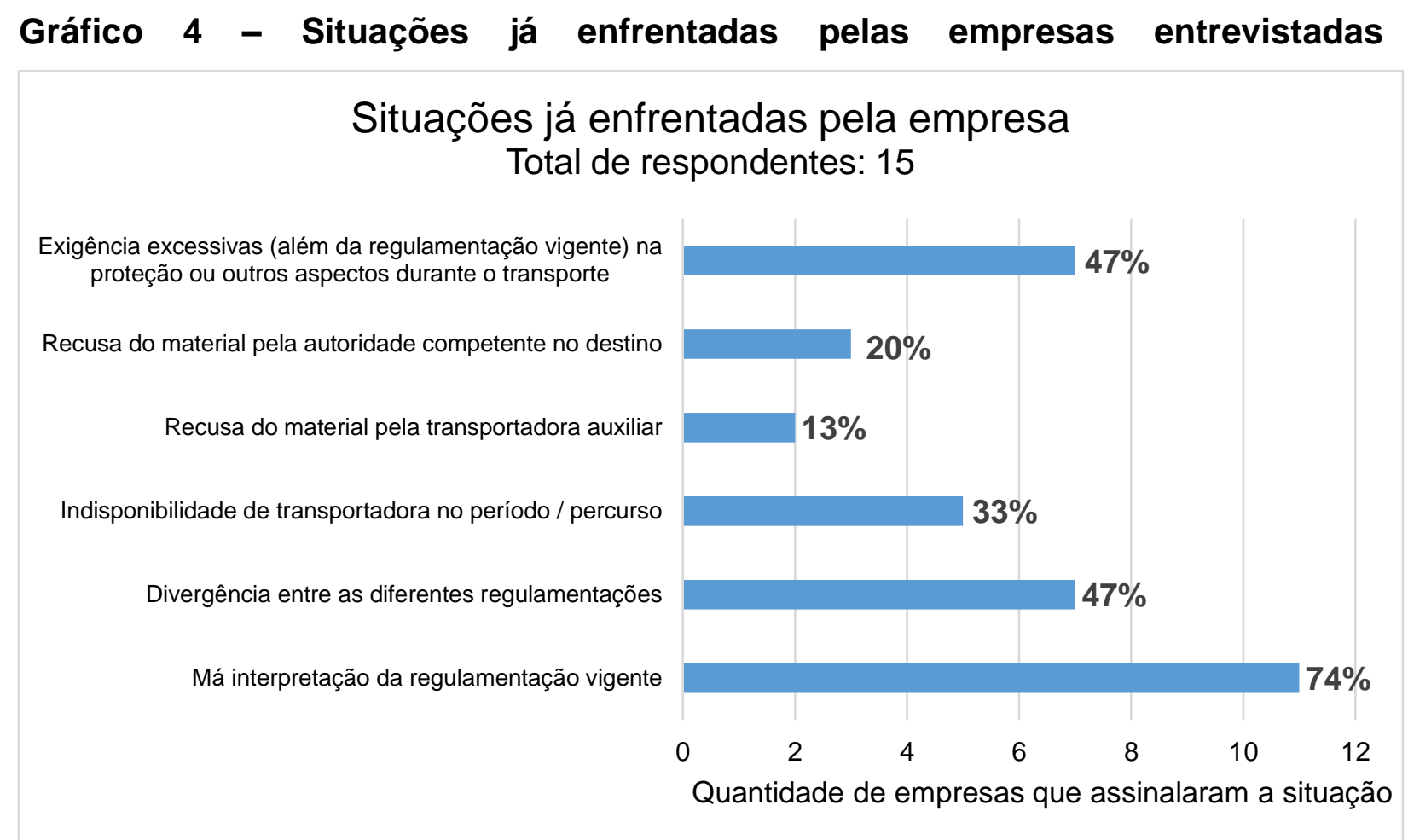

Fonte: autor da dissertação.

Percebe-se que o problema mais comum se dá ao lidar com a regulamentação vigente. As más interpretações, divergências e exigências excessivas são os itens mais assinalados pelas empresas. A recusa do material radioativo por uma transportadora auxiliar ou pela autoridade competente no destino podem estar relacionados não só com os problemas regulamentares, mas também com dois motivos indicados anteriormente pelo OIEA e pela ANTT, que são a apreensão em relação ao material radioativo e a falta de informação sobre a segurança do transporte. Além de interpretarem mal as regulamentações ou exigirem procedimentos além destas, o medo da radiação ionizante e a falta de informação contribuem para o evento de recusa. Do mesmo modo, a indisponibilidade de transportadoras pode ter relação com o medo e falta de informação, afora o custo e exigências que fazem com que as empresas não tenham interesse pelo mercado. 


\subsection{Recusas e demoras de acordo com o modal de transporte}

Além da motivação, perguntou-se aos expedidores e transportadores de material radioativo qual modal sofria com maior incidência de recusa e demora, ou enfrentava mais problemas durante o transporte. Os dados encontram-se nos gráficos 5 e 6 . Os respondentes são transportadores de materiais radioativos dos modais terrestre e aéreo e expedidores de material radioativo. O gráfico 5 mostra o modal em que os respondentes têm maiores problemas em sua empresa durante o transporte. Estes dados refletem a realidade nas instituições dos respondentes. Já o gráfico 6 mostra o modal que, na opinião dos respondentes, sofre com maiores problemas considerando o cenário nacional, isto é, não corresponde à realidade da instituição do respondente, mas sim à sua opinião sobre o que ocorre no país. Cada respondente corresponde, idealmente, a uma instituição ou empresa.

Gráfico 5 - Modal de transporte com maior incidência de problemas na empresa respondente

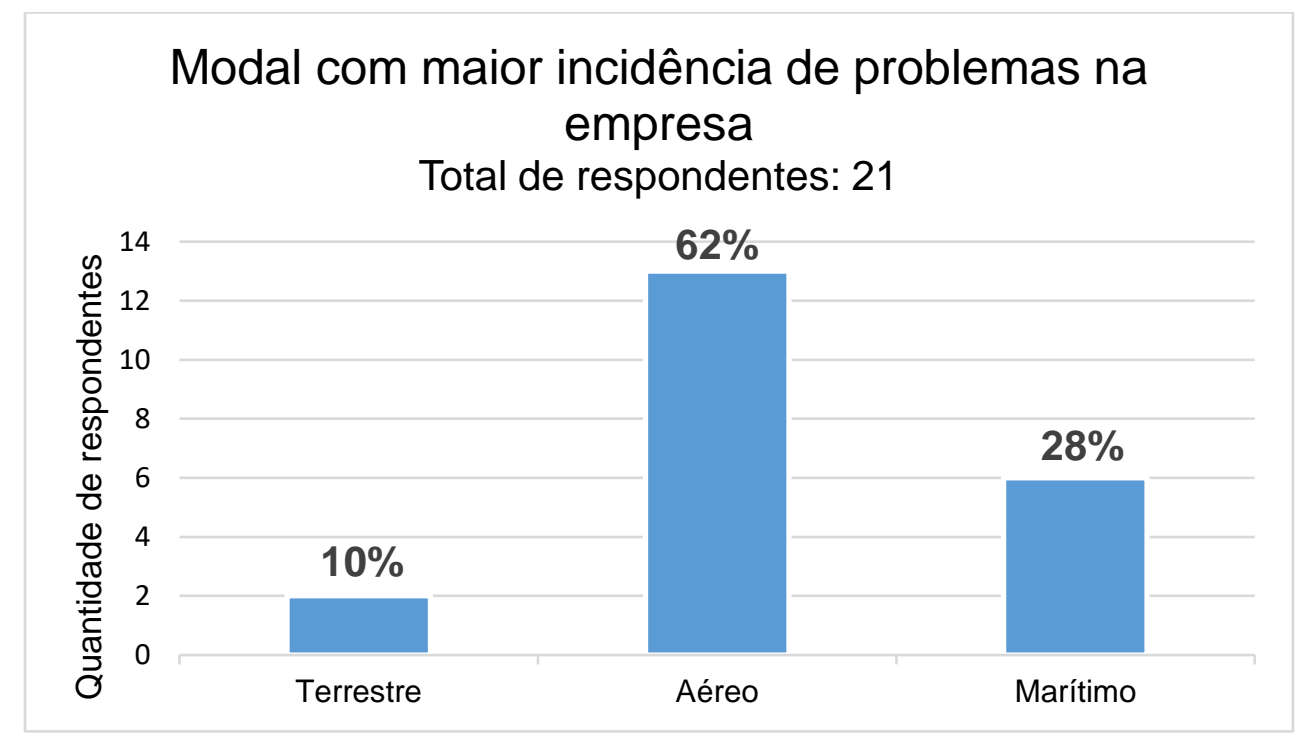

Fonte: autor da dissertação. 


\section{Gráfico 6 - Modal de transporte com maior incidência de problemas - opinião do respondente}

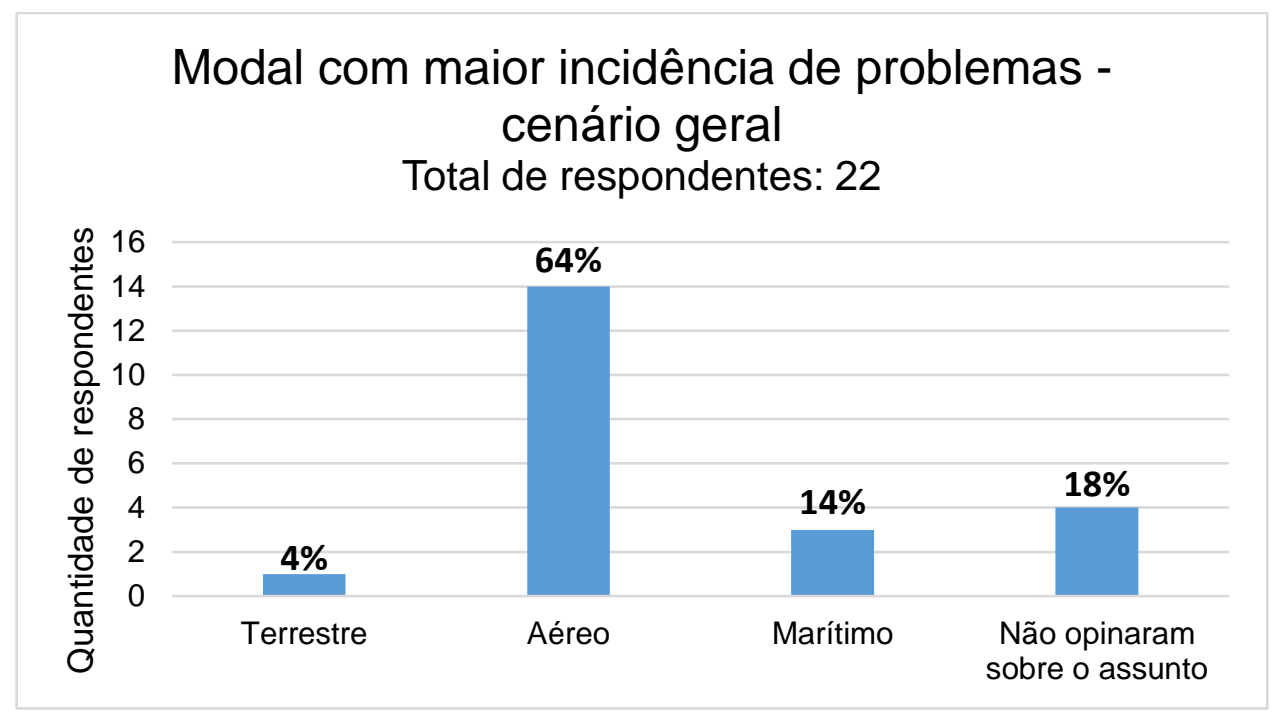

Fonte: autor da dissertação

Para eles, o modal com maiores problemas é o aéreo, seguido pelo marítimo e, por último, o terrestre. O modal aéreo é responsável, principalmente, pelo transporte de radiofármacos utilizados na medicina nuclear para diagnóstico e tratamento. São materiais de meia-vida curta e os problemas encontrados, não só para o aéreo mas como para os demais modais, encontram-se descritos a seguir.

\subsection{Descrição dos problemas enfrentados}

Ao decorrer deste trabalho, foram entrevistadas diversas partes envolvidas no transporte de materiais radioativos, como descrito no capítulo 3. Esta parte do trabalho se dedica à descrição dos problemas relatados por participantes de órgãos regulatórios, transportadores de materiais radioativos, transportadores de produtos perigosos, expedidores de materiais radioativos e unidades a que o material radioativo é destinado.

\subsubsection{Problemas com o fornecimento de relatos}

Dentre todos os participantes de reuniões nacionais e internacionais, há o consenso de que o relato dos eventos de recusa e demora são cruciais para a busca de soluções. Assim, empresas que sofrem com o problema são estimuladas a relatarem aos comitês ou às entidades regulatórias competentes as ocorrências [1, 2, 7]. 
Porém, as empresas não estão propensas a divulgar estes relatos ou compartilha-los publicamente. Isso ocorre porque há uma apreensão de que a divulgação dos problemas ocorridos cause mais prejuízos à empresa, além daqueles já sofridos com o problema. Se uma empresa, por exemplo, sofre com problemas frequentes de recusa e demora no transporte, os clientes não se sentirão seguros para deixar sua carga sob custódia desta empresa, reduzindo, assim, a demanda ou a carteira de clientes.

Outro fator que desestimula a divulgação ou o fornecimento de relatos é a forma como este é solicitado pelo OIEA e pelos Comitês. O formulário de relato (ANEXO 1) solicita dados como a identificação da empresa, do relator, o tipo de material radioativo, a rota e outras informações que fornecem dados estratégicos, fazendo com que o negócio da empresa, clientes, prestadores de serviço auxiliares e outras instituições sejam expostas. Esta exposição não é desejada, principalmente se considerarmos que os interessados nos relatos são, em boa parte, outras empresas do mesmo ramo, ou seja, concorrentes. Assim, como o formulário não garante o anonimato, as empresas preferem não divulgar o relato e lidar com o problema a ter informações cruciais de seu funcionamento expostas. Segundo os entrevistados, esse problema ocorre não só no Brasil, mas também na maioria dos países participantes dos comitês.

Apesar de não corresponder a um problema direto com o transporte de material radioativo, este problema acaba por interferir nas possíveis soluções. O não reporte dos acontecimentos faz com que o problema seja subestimado, não ganhando as visibilidade e atenção necessárias. Além disso, limita a troca de experiências entre as empresas e, soluções já encontradas por algumas em certa situação, ficam desconhecidas por outras, fazendo com que um mesmo problema se repita para diferentes empresas quando poderia ter sido evitado.

Na maioria dos casos, a empresa chega a reportar o problema ocorrido à autoridade competente, que auxilia na resolução, mas não permite sua divulgação. Desta maneira, a autoridade competente não pode divulgar entre as demais empresas do mesmo ramo o fato ocorrido. Porém, isto gera experiência na tratativa dos casos, fazendo com que a autoridade competente possa auxiliar as demais empresas que passem pelo mesmo problema caso estas também entrem em contato. Ainda assim, 
esta situação difere muito do idealizado nos planos de ação internacional e nacional, que preza pela divulgação e comunicação dos problemas e das ações de forma aberta.

\subsubsection{Processo burocrático e dificuldade de adaptação}

A palavra burocracia é utilizada para denominar os processos pelos quais a administração pública é realizada. Porém, no Brasil, o termo é mais associado a significados pejorativos, como disfuncionalidade administrativa e caráter antidemocrático [26]. Torres (2004) explica que a palavra é associada a uma situação muito recorrente no país: a hipertrofia de estruturas administrativas, ou a "superposição de uma série de etapas desnecessárias ao longo de um processo ou procedimento administrativo". Este fato ocorre porque o estado brasileiro tende a ser intervencionista e pesado, já que, ao longo dos séculos, vem acumulando muitas atribuições econômicas importantes [26].

Além disto, o estado brasileiro tem como preceito a descentralização. O poder público, idealmente, seria distribuído entre a união (federação), os estados e os municípios, cumprindo uma hierarquia [26]. A descentralização do poder legislativo e executivo, característico deste modelo, é o que acarreta parte dos problemas tratados por este trabalho. Apesar da idealização ser ótima, visando o não acúmulo de poder em um conjunto restrito de indivíduos e a distribuição dos deveres para otimizar a burocracia, o que ocorre na prática é uma excessividade de atuação do poder público. Este aspecto se manifesta, para o transporte de materiais radioativos, pela grande quantidade de normas em vigor, que são repetitivas e algumas vezes discrepantes ou não importantes para a segurança no transporte.

Como relatado anteriormente, a regulamentação vigente é o motivo que mais causa problemas aos entrevistados. E, não só pela má interpretação ou por divergências, ver-se-á que a quantidade de exigências e a dificuldade de adaptação a elas influenciam diretamente na indisponibilidade de transportadoras.

Internacionalmente, o transporte de materiais radioativos e de outros produtos perigosos é tratado pelo Livro Laranja (Orange Book). O Livro Laranja é um guia criado pela Organização das Nações Unidas (ONU) que fornece orientações para o transporte seguro de acordo com o produto perigoso a ser transportado. Apesar de não constituir uma normatização, este documento é a base informativa para a 
elaboração de normatizações internacionais e nacionais. Idealiza-se que os procedimentos de segurança adotados no transporte devem ser harmônicos nos diferentes países do mundo [27]. Logo, os países que fazem parte da ONU, como o Brasil, tendem a seguir as orientações do Livro Laranja em suas normas. Além disso, outros organismos internacionais também o fazem, como a Organização Marítima Internacional (OMI / International Maritime Organization - IMO) e a Organização Internacional de Aviação Civil (OACI / International Civil Aviation Organization - ICAO), que fornecem documentos regulatórios para seus respectivos modais quando este ocorre internacionalmente [19, 28].

A Tabela 5 contém as regulamentações vigentes para o transporte de materiais radioativos em uma estância federal. Ou seja, são normas de órgãos cuja competência para regulamentar foi instituída por lei federal, estando acima de normatizações estaduais ou municipais em caso de divergências [29].

Além destes, o transporte de materiais radioativos ainda está sujeito a normatizações criadas pelos estados e municípios do país, já que estes, segundo a constituição federal, possuem autonomia legislativa e podem complementar a normatização federal [29].

Para possíveis divergências, tem-se como recurso o artigo no24 da constituição, que diz que "a superveniência de lei federal sobre normas gerais suspende a eficácia da lei estadual, no que lhe for contrário". Assim, leis e normas de órgãos federais sobrepõem-se, em poder, às estaduais. Do mesmo modo, leis e normas de órgãos municipais ficam submetidas às estaduais e federais. Um município deve "suplementar a legislação federal e a estadual no que couber", agindo somente de forma complementar em casos locais para os quais as legislações federal ou estadual não se aplicam ou não existem de forma a atender as necessidades da situação [29]. 
Tabela 5 - Legislação vigente na regulamentação do transporte de materiais radioativos no Brasil em âmbito federal

\begin{tabular}{|c|c|c|c|}
\hline $\begin{array}{l}\text { Modal do } \\
\text { transporte }\end{array}$ & $\begin{array}{l}\text { Órgãos que o } \\
\text { regulamentam }\end{array}$ & Normas vigentes & $\begin{array}{c}\text { Ano em que a } \\
\text { última } \\
\text { atualização } \\
\text { entrou em vigor }\end{array}$ \\
\hline \multirow{8}{*}{$\begin{array}{l}\text { Terrestre: } \\
\text { Rodoviário }\end{array}$} & \multirow{5}{*}{$\mathrm{ABNT}^{[\mathrm{a}]}$} & NBR 14095 & 2008 \\
\hline & & NBR 7500 & 2018 \\
\hline & & NBR 7501 & 2011 \\
\hline & & NBR 7503 & 2018 \\
\hline & & NBR 9735 & 2017 \\
\hline & ANTT[d] & Resolução no 5232 & 2016 \\
\hline & CNEN[e] & NR 5.01 & 1988 \\
\hline & IBAMA $^{[f]}$ & IN no05 & 2012 \\
\hline \multirow{4}{*}{$\begin{array}{l}\text { Terrestre: } \\
\text { Ferroviário }\end{array}$} & $A B N T^{[a]}$ & NBR 9735 & 2016 \\
\hline & ANTT[d] & Resolução no 5232 & 2016 \\
\hline & CNEN[e] & NR 5.01 & 1988 \\
\hline & IBAMA $^{[f]}$ & IN no05 & 2012 \\
\hline \multirow{2}{*}{ Aéreo } & ANAC $[b]$ & RBAC 175 & 2018 \\
\hline & CNEN $[\mathrm{e}]$ & NR 5.01 & 1988 \\
\hline \multirow{4}{*}{ Marítimo } & ANTAQ $^{[c]}$ & Resolução no 2239 & 2011 \\
\hline & CNEN $[\mathrm{e}]$ & NR 5.01 & 1988 \\
\hline & IBAMA $^{[f]}$ & IN no05 & 2012 \\
\hline & Marinha do Brasil - & NORMAM n01 & 2018 \\
\hline
\end{tabular}

[a]ABNT: Associação Brasileira de Normas Técnicas

[b]ANAC: Agência Nacional de Aviação Civil

[c]ANTAQ: Agência Nacional de Transportes Aquaviários

[d]ANTT: Agência Nacional de Transportes Terrestres

[e]CNEN: Comissão Nacional de Energia Nuclear

[f]BAMA: Instituto Brasileiro do Meio Ambiente e dos Recursos Naturais Renováveis

[9]Marinha do Brasil - DPC: Diretoria dos Portos e Costa

Compilado pelo autor da dissertação. Fontes: Associação Brasileira de Normas Técnicas. Consulta de normas vigentes disponível em < https://www.abntcatalogo.com.br/>. Acessado em 24/09/2019; Referências [4, 17, 34, 37, 47]; Marinha do Brasil - Diretoria de Portos e Costas. NORMAM no 01, 2018. Marinha do Brasil - Diretoria de Portos e Costas. NORMAM nํ02, 2018. 
Ainda assim, esta tratativa só pode ser utilizada em caso de divergência das normas de um órgão federal para um estadual ou municipal. Entre órgãos federais, a solução dependerá da alteração ou adequação de uma ou ambas as normas. Nesse sentido, o Comitê Nacional se mostra de grande valia, promovendo o encontro entre os representantes dos órgãos reguladores e possibilitando a harmonização da legislação.

Além disso, ainda há possibilidade de que sejam instituídas regulamentações estaduais ou municipais que não sejam contrárias às federais, mas que exijam procedimentos além daquelas, tornado o processo de adaptação fadigante e oneroso ao empreendedor. Muitas vezes, as exigências estabelecidas nada contribuem para o aumento da segurança, que é a oratória utilizada para que estas sejam criadas. Isto faz com que o transporte fique mais caro e difícil de ser realizado, mas não mais seguro.

As múltiplas atribuições enumeradas na Tabela 5 provocaram e ainda provocam em diversos modais problemas com a adaptação das empresas, que se agravam em momentos de transição das normas. Seguem descritos alguns casos em que o processo burocrático envolvendo esses diversos órgãos normativos causaram problemas no transporte de materiais radioativos.

Dois dos principais casos discutidos e trabalhados pelo Comitê Nacional encontram-se descritos a seguir. Por meio deles, é possível verificar o que foi dito anteriormente, observando-se a dificuldade de adaptação às legislações.

O Conselho Nacional do Meio Ambiente (CONAMA) é um órgão consultivo e deliberativo do Sistema Nacional do Meio Ambiente. Este órgão recebeu a função de estabelecer normas e critérios para o licenciamento de atividades efetiva ou potencialmente poluidoras pela lei $\mathrm{n}=6.938$ de 1981. A função de implementar as normas estabelecidas pelo CONAMA foi atribuída ao Instituto Brasileiro do Meio Ambiente e dos Recursos Naturais Renováveis (IBAMA). Ou seja, ao que se refere à legislação ambiental nacional, o CONAMA realiza o trabalho legislativo, enquanto o IBAMA realiza o trabalho executivo [30]. Em 1997, o CONAMA, por meio da Resolução no 237, instituiu ao IBAMA, a função de realizar o licenciamento ambiental para atividades que poderiam ter impacto ambiental significativo. A Licença Ambiental, mais especificamente, estabelece as condições, restrições e medidas de controle ambiental que deverão ser obedecidas pelo empreendedor, pessoa física ou jurídica que estará 
realizando a atividade que deve ser licenciada pelo órgão. Entre as atividades, incluise o transporte de materiais radioativos. O trecho que fornece esta decisão é dado a seguir e foi retirado da resolução citada:

Compete ao Instituto Brasileiro do Meio Ambiente e dos Recursos Naturais Renováveis... o licenciamento ambiental... de empreendimentos e atividades com significativo impacto ambiental de âmbito nacional ou regional... destinados a pesquisar, lavrar, produzir, beneficiar, transportar, armazenar e dispor material radioativo, em qualquer estágio, ou que utilizem energia nuclear em qualquer de suas formas e aplicações, mediante parecer da Comissão Nacional de Energia Nuclear - CNEN.

Logo, o transporte de materiais radioativos marítimo e/ou interestadual fica sujeito às normatizações do IBAMA e da CNEN, conjuntamente, de acordo com este documento. Além disso, a Resolução № 237 [31] ainda especifica que:

O CONAMA definirá, quando necessário, licenças ambientais específicas, observadas a natureza, características e peculiaridades da atividade ou empreendimento e, ainda, a compatibilização do processo de licenciamento com as etapas de planejamento, implantação e operação.

Portanto, o transporte de materiais radioativos deve estar de acordo com as exigências especificadas em ambos os órgãos [30, 31].

Apesar de não demonstrarem contradições entre si, ambas as normas solicitavam a elaboração de um documento denominado Plano de Transporte (PGT), que deveria passar por avaliação de cada um dos órgãos, gerando a autorização ou o licenciamento para realizar o transporte de materiais radioativos. Neste caso, o mesmo documento e exigências eram realizados por dois órgãos distintos e acarretavam ônus com licenciamentos que deveriam ser feitos para cumprir um mesmo propósito. Transportadores relataram que isso tornava o transporte muito oneroso e não incrementava em nada a segurança, já que se tratavam dos mesmos documentos e exigências, porém feitos em duplicidade. Além disso, o licenciamento tanto para a CNEN quanto para o IBAMA é realizado com base no tipo de material radioativo transportado, selecionado pelo tipo de embalado que limita certa atividade. Logo, se um transportador trabalhasse com duas classes de embalado, teria de realizar quatro processos de licenciamento. Alguns transportadores informaram que, dependendo do volume de transporte que tinham com um certo tipo de embalado, compensava perder o cliente ou a demanda que arcar com os custos dos licenciamentos, tornando o transporte inviável economicamente ou desinteressante. 
Para resolver estes conflitos, em 2007 a CNEN e o IBAMA reuniram esforços para criar um "Termo de Referência", que dispunha das condições necessárias para o transporte de materiais radioativos e limitava certos assuntos à CNEN ou ao IBAMA, reduzindo a dupla atribuição de funções e necessidade de licenciamentos. O Termo de Referência não possuía valor regulatório, mas constituiu um documento que orientava o transportador sobre as exigências a serem cumpridas para cada tipo de material radioativo de acordo com o respectivo embalado. Esta orientação se mostrou mais didática e proporcionou maior facilidade de adaptação e cumprimento a ambas as normas em vigência naquele período [4, 5, 32].

Posteriormente, os critérios foram atualizados. Em 2011, houve a publicação da Lei Complementar $n^{\circ} 140$ [33], que reforçava, no artigo 7ํㅜ, a obrigatoriedade da União com a execução da Lei Ambiental, mantendo o disposto pela Resolução nำ 237 [31]. Além disso, dispunha que deveria ser realizado o controle ambiental sobre o transporte marítimo de produtos perigosos e, se interestadual, também o controle fluvial e terrestre. Como a Resolução no 237 [31] atribui estas competências ao IBAMA, ele, em resposta publicou a Instrução Normativa no 5 de 09 de maio de 2012 [34]. Nesta normativa, estabeleceu a criação do Sistema Nacional de Transporte de Produtos Perigosos, que seria um sistema automatizado, interativo e simplificado, com preenchimento de formulários eletrônicos para execução do controle disposto na lei complementar. Enquanto a implantação do sistema não ocorresse, o transportador de produtos perigosos, incluindo a classe 7, deveria portar um documento intitulado "Autorização Ambiental para Transporte de Produtos Perigosos", concedido àqueles que já possuíam o Certificado de Regularidade Ambiental (feito na fase de licenciamento das atividades junto ao IBAMA) com validade de 3 meses a partir de sua emissão. Era obrigatório o porte de uma cópia da autorização em cada veículo ou unidade transportadora que realizasse aquele tipo de trabalho, além das devidas regulamentações emitidas pela ANTT, ANTAQ e Marinha do Brasil, a depender do modal $[31,34]$.

Atualmente, a autorização ambiental para transporte é realizada digitalmente pelo sítio do IBAMA, quando o transportador realiza a inventariação no Cadastro Técnico Federal de Atividades Potencialmente Poluidoras e/ou Utilizadoras de Recursos Ambientais (CTF/APP) [35]. Esta autorização é gratuita e complementa o licenciamento, que, atualmente, abrange somente alguns tipos de embalados e 
situações em que a atividade transportada oferece maior risco (maior atividade ou produto físsil), ficando o restante sob responsabilidade da CNEN.

Assim, com algumas mudanças, o Termo de Referência conjunto já não atendia a alguns aspectos e tinha de ser alterado para adequar-se à nova realidade do IBAMA, gerando mais um processo adaptativo aos transportadores. Em 2013, uma Nota Técnica Conjunta foi emitida entre IBAMA e CNEN. Nela, constam instruções e orientações de como obter as autorizações da CNEN, do IBAMA e em que casos ela deveria ser requisitada. $O$ documento foi formulado em um esforço conjunto entre as duas instituições, que elaboraram um modelo de Plano de Transporte que atendesse às normatizações de ambos os órgãos reguladores e pudesse ser utilizado pelos interessados como base, reduzindo atribuições duplicadas e que não contribuíssem para segurança do transporte [32].

Observa-se que todo este processo de transição e adaptação de normas foi causado pela dualidade de atribuição fiscal de um mesmo aspecto, o transporte de materiais radioativos. No seu decorrer, diversos envolvidos foram mobilizados pelo Comitê Nacional para formularem uma solução que conseguisse atender ao expedidor, ao transportador, aos usuários e aos órgãos regulatórios. Outro caso parecido, mas com problemas de incompatibilidades entre normas, aconteceu entre as normas da CNEN e da ANNT.

A lei federal no 10.233 de 2001 criou a Agência Nacional de Transportes Terrestres (ANTT) e determinou que se inclui na sua esfera de atuação o transporte de produtos perigosos em rodovia e ferrovias. São de sua função a criação de normas federais para o transporte ferroviário e rodoviário, bem como a fiscalização do cumprimento destas e estabelecimento e execução medidas punitivas para o não cumprimento [36].

O transporte de produtos perigosos era regulamentado pela ANTT por meio da Resolução 420/04 de 2004 e suas atualizações [5]. Em 2016, a ANTT abriu o processo para revogação destas normas e sua atualização pela Resolução nํ 5.232 [37]. Houve sessão de consulta pública para recebimento de contribuições e, um dos principais objetivos era o alinhamento de suas normas com as orientações do Livro Laranja até sua 18ำ edição [38, 39]. A atualização foi publicada em dezembro de 2016 e revoga as antigas normas vigentes no transporte de produtos perigosos [37]. 
Foi relatado a esta pesquisa que durante o vigor da Resolução ANTT $\cong 420$ de 2004 [5], haviam incompatibilidades entre esta e a norma CNEN 5.01 [4]. Os transportadores não conseguiam aderir às duas normas em todos os aspectos, causando problemas adaptativos e de fiscalização. Infelizmente, não se teve acesso a Resolução ANTT n־420 de 2004 em sua integralidade para possíveis comparações, mas os relatos informam problemas de classificação dos embalados, discrepâncias entre os números ONU fornecidos, divergências na quantidade de atividade radioativa permitida e outras exigências de segurança da ANTT que dificilmente conseguiam ser aplicadas ao transporte de materiais radioativos. Em 2008 a norma sofreu sua primeira alteração e iniciou, mesmo antes do surgimento do Comitê Nacional, a harmonização entre ANTT e CNEN por meio da Resolução ㄲo2.657 de 15 de abril de 2008 [6]. Nela, aspectos como a classificação, limitação de transporte e requisitos para embalados contendo material radioativo foram excluídos, solicitando que se atendesse e verificasse as normas da CNEN [6] Outra atualização ocorreu em 2016 na publicação da Resolução n5.232, que já contou com a participação ativa do Comitê Nacional em sua revisão [37].

No que se diz respeito a classificação dos embalados, disposição especial para embalagens e disposições especiais para o transporte, a nova resolução facilitou a compatibilidade com a norma da CNEN. Basicamente, a nova norma redireciona todas as exigências para o atendimento das normas da CNEN. Os trechos encontrados sobre a classe 7 na Resolução 5.232 da ANTT [37] são dados a seguir:

Para fins de classificação dos materiais radioativos e alocação aos números ONU, deve ser atendido o disposto nas Normas para Transporte estabelecidas pela Comissão Nacional de Energia Nuclear - CNEN.

As disposições gerais, especiais exigências e demais controles relativos às embalagens utilizadas no transporte terrestre de materiais radioativos, estão estabelecidas nas normas da CNEN.

As disposições especiais aplicáveis ao transporte de material radioativo estão estabelecidas pela regulamentação da CNEN.

As únicas especificações sobre a classe 7 encontram-se na rotulação da embalagem de transporte, que fornece o rótulo adequado para transporte e instruções para a identificação do veículo, e na indicação dos números ONU. Sem dúvidas, esta alteração facilita grandemente o cumprimento das normatizações, reduzindo a possibilidade de ocorrência de erros por dupla ou má interpretação. 
Após as alterações, as duas incompatibilidades entre as normas CNEN e a ANTT mais recente (2016) que permanecem são listadas na Tabela 6 [4, 37]. Existem também algumas incompatibilidades entre as resoluções ANNT oㅡ.657 de 2008 e ำ5.232 de 2016, especialmente nas tabelas de classificação utilizando o número ONU $[6,37]$. A resolução no2657 é facilmente encontrada na internet com a tabela divergente de sua atualização, apesar de já ter sido revogada.

Tabela 6 - Inconsistências entre a norma CNEN 5.01 e as Resolução ANTT no5.232

\begin{tabular}{|c|c|c|}
\hline Incompatibilidade & CNEN 5.01 & ANTT $n \div 5.232$ \\
\hline $\begin{array}{l}\text { Classificação por } \\
\text { número ONU }\end{array}$ & $\begin{array}{l}\text { Inexistência dos números ONU } \\
2915,2916,2917,2919,3321, \\
\text { 3322, 3323, 3324, 3325, 3326, } \\
\text { 3327, 3328, 3329, 3330, 3331, } \\
\text { 3332, 3333 utilizados na ANTT. } \\
\text { Existência dos números ONU } \\
\text { 2918, 2974, 2975, 2976, } 2977 \text {, } \\
\text { 2978, 2979, 2980, } 2981 \text { e } 2982 \\
\text { não presentes na ANTT. }\end{array}$ & $\begin{array}{l}\text { Inexistência dos números ONU } \\
2918,2974,2975,2976,2977 \text {, } \\
2978,2979,2980,2981 \text { e } 2982 \\
\text { utilizados na CNEN. } \\
\text { Existência dos números ONU } \\
\text { 2915, 2916, 2917, 2919, 3321, } \\
\text { 3322, 3323, 3324, 3325, 3326, } \\
\text { 3327, 3328, 3329, 3330, 3331, } \\
\text { 3332, } 3333 \text { não presentes na } \\
\text { CNEN. }\end{array}$ \\
\hline $\begin{array}{l}\text { Tamanho do } \\
\text { rótulo ou placa } \\
\text { indicativa de } \\
\text { material } \\
\text { radioativo }\end{array}$ & $\begin{array}{l}\text { Dimensão mínima estabelecida } \\
\text { em } 10 \mathrm{~cm}(100 \mathrm{~mm}) \text { para fixação } \\
\text { em lados opostos, não citando } \\
\text { variações de tamanho para } \\
\text { embalagens de tamanho } \\
\text { pequeno. }\end{array}$ & $\begin{array}{l}\text { Dimensões mínimas expostas } \\
\text { de acordo com a norma ABNT } \\
7500 \text {, com possibilidade de } \\
\text { redução de tamanho para } \\
\text { embalagens pequenas. A } \\
\text { dimensão de } 10 \mathrm{~cm} \text { só é exigida } \\
\text { para embalagens que } \\
\text { comportem acima de } 25 \\
\text { quilogramas. }\end{array}$ \\
\hline
\end{tabular}

Fonte: autor da dissertação.

4.3.3 Incompatibilidade entre as legislações

As normatizações vigentes para o transporte de materiais radioativos no país encontram-se na Tabela 5. 
No Brasil, as divergências entre as legislações ocorrem de duas maneiras: entre as normas nacionais e entre as normas nacionais em relação às internacionais. Boa parte dessas incompatibilidades é causada pela defasagem de algumas normas nacionais em relação a outras mais recentes. Em outros casos, quando há dualidade de atribuição da fiscalização de determinada atividade, as normas são elaboradas separadamente e sem harmonização por diferentes órgãos governamentais.

Neste cenário, a norma CNEN 5.01 é o principal documento do órgão federal que regulamenta o transporte de material radioativo. Porém, o documento data de 1988, não sofrendo alteração até a presente data (dezembro de 2018) [4]. Outros órgãos reguladores, como a ANTT e ANAC, possuem normas mais recentes, posteriores a 2010 [17, 37]. Além disso, o transporte de materiais radioativos segue, internacionalmente, as orientações do guia da ONU, isto é, Livro Laranja, que teve sua última atualização em 2017 [3]. Os países membros das Nações Unidas não tem a obrigatoriedade de seguir o livro laranja, porém, este é criado por um grupo de especialistas e tem o objetivo de instruir os órgãos nacionais e internacionais, promovendo a harmonização entre as legislações e práticas aplicadas em todo o mundo. Logo, se um país adere às orientações do livro laranja e outro não, divergências irão surgir e poderão causar problemas.

Apesar de sua defasagem, a norma CNEN NN 5.01 [4] conta com uma informação que Ihe possibilita amenizar as inadequações de seu conteúdo em relação às demais normas nacionais e internacionais. No subitem 2.1.2, a norma diz que:

A CNEN pode, através de Resolução, substituir e/ou acrescentar requisitos aos constantes desta Norma, conforme considerar apropriado ou necessário.

Mesmo não possuindo, literalmente, resoluções publicadas que alterem a norma de transporte, soube-se por meio de entrevista com um dos funcionários responsáveis pelo setor competente que a CNEN tem se utilizado deste subitem para lidar com as inconsistências existentes. Ao entrar em contato com a CNEN, o transportador é orientado a seguir os conteúdos mais recentes publicados pelo OIEA e pelo Orange Book. Em um cenário internacional, este já é o procedimento ideal e, para o transporte em território nacional, esta atitude tende a se adequar às exigências de normas mais atualizadas. Além disso, já bem a par das divergências entre normas, os 
fiscais da CNEN não tendem a penalizar o transportador que esteja de acordo com as demais normatizações, mas em desacordo com os aspectos defasados da NN 5.01.

Durante $011^{\circ}$ encontro de recusas e demoras, foi esclarecido que a revisão da CNEN NN 5.01 foi finalizada, aproximadamente, em 2012. Porém, depende da divisão de Segurança e Normatização publicar o documento e, por parte do setor de transportes, não se sabe qual o motivo da demora.

Ainda assim, as divergências existentes fazem com que agentes fiscais que as desconhecem multem os transportadores ou tomem ações que geram recusas e demoras. Mesmo que as autoridades regulatórias intervenham e consigam a solução para o problema, isto causa, no mínimo, um transtorno temporário.

As divergências encontradas por este trabalho e as relatadas pelos entrevistados encontram-se descritas a seguir.

4.3.3.1 Dificuldades relatadas por divergências entre a norma CNEN 5.01 e outras normatizações nacionais e internacionais

A primeira inconsistência e a mais citada a respeito da norma 5.01 da CNEN é a divergência dos números ONU que identificam o material e, obrigatoriamente, devem estar presentes nos documentos e sinalizações de transporte. Dos 16 números presentes na tabela da norma, apenas 6 permanecem em uso e ainda correspondem aos utilizados pela ONU e estão presentes no documento de 2018 do OIEA para o transporte de materiais radioativos. Além disso, a lista completa do OIEA do ano de 2018 conta com 26 números diferentes. Ou seja, 10 a mais do que os referenciados na CNEN 5.01, sendo que 20 são divergentes [4, 40]. A Tabela 6 também mostrou a presença desta incompatibilidade com a norma da ANTT [37].

As categorias de materiais para classificação também diferem. Na norma CNEN 5.01 existem duas classes de Objeto Contaminado na Superfície: OCS-I e OCSII. Para o OIEA existem 3 classes: OCS-I, OCS-II e OCS-III.

Outro assunto é a classificação dos embalados exceptivos. Apesar de não constituir uma incompatibilidade, a forma como a classificação deste embalado é decrita na CNEN 5.01 e nas normas internacionais abre espaço à dupla interpretação. Na CNEN 5.01 para um embalado ser classificado como exceptivo deve cumprir um limite estabelecido na norma não maior que $5 \mu \mathrm{Sv} / \mathrm{h}$ (micro-Sieverts / hora) em qualquer 
ponto de sua superfície externa, caso sejam compostos por outros materiais radioativos que não o urânio natural, urânio empobrecido ou tório natural. Assim, o cálculo do IT representará um número desprezível. Ou, de acordo com o item 5.2.3.2, quando constituem artigos fabricados de urânio natural, urânio empobrecido ou tório natural, os embalados exceptivos podem conter qualquer quantidade desses materiais, desde que a superfície externa do urânio ou do tório seja protegida por um revestimento inativo de metal ou de alguma outra substância resistente. Mesmo assim, há uma outra restrição baseada em valores que limitam a atividade contida em um único embalado, independentemente de seu IT exterior. O material pode ser classificado como exceptivo pela mediação de IT após embalado, mas não se enquadrar no embalado exceptivo por possuir atividade interior maior que as relacionadas nas tabelas da norma. Assim, se enquadram em embalados do tipo A ou do tipo B. Sob algumas condições, embalagens vazias que contiveram material radioativo também podem ser classificadas como exceptivas [4].

Tanto o OIEA quanto a OMI utilizam uma classificação idêntica, que mantém praticamente as mesmas exigências [19, 40]. Porém, a disposição das informações das restrições ao longo do texto é mais confusa internacionalmente. Para os envolvidos com o transporte da classe 7 e habituados ao tema, isto não é problema. Porém, para outros indivíduos, envolvidos ou não com o transporte de produtos perigosos, a interpretação pode ser diferente, já que não possuem um conhecimento aprofundado do transporte da classe 7. Na CNEN 5.01, por exemplo, a cada condição dada, é exposto no mesmo local e parágrafo quais outras exigências devem ser cumpridas. Ou seja, em cada parágrafo ou nova informação sobre a classificação de embalados exceptivos, são indicados quais outros requisitos também devem ser cumpridos e que se encontram ao longo da norma. Isto não acontece de forma tão efetiva nas normas internacionais, na qual o leitor encontra as mesmas informações, mas de forma mais dispersa ao longo da redação e com trechos que, por vezes, não indicam a existência do cumprimento de requisitos adicionais.

Houveram relatos de problemas recorrentes em que o embalado foi classificado no Brasil como tipo A, tendo seus documentos preenchidos desta forma, e reclassificado no porto ou no exterior como exceptivo, baseados nas normas internacionais marítimas $[4,19]$. Isto acontece por má interpretação da normatização neste caso, que é o problema mais recorrente como mostrado no gráfico 4. 
Outra divergência é a do símbolo padrão de radioatividade utilizado nacionalmente. A norma CNEN 5.01 difere da resolução ANTT 5.232 e norma ABNT 7500, como mostrado na Tabela 6. A primeira diferença é a possiblidade de dimensões reduzidas do símbolo para embalagens pequenas. A ANTT e a ABNT permitem rótulos com dimensões mínimas que variam de $15 \mathrm{~mm}$ a $50 \mathrm{~mm}$ para embalagens que contenham menos de $25 \mathrm{~kg}$. No caso da CNEN, a dimensão mínima do rótulo é de $100 \mathrm{~mm}$ independente do tamanho do embalado [4, 37, 41]. Houve relato de um transportador que foi multado por um agente fiscal, já que o rótulo localizado no veículo não continha as dimensões de borda especificadas na norma ABNT, apesar de estar adequado à norma da CNEN.

4.3.3.2 Dificuldades entre a legislação do município de São Paulo e demais legislações federais

No município de São Paulo, encontra-se em vigor o decreto municipal oㅜ 50.446 de 2009, que regulamenta o transporte de produtos perigosos dentro do município [42]. Apesar de válido para esta cidade, o decreto tem impacto direto no transporte de materiais radioativos que se destinam a outros municípios, estados e países.

A cidade de São Paulo possui 50 dos 434 (11\%) serviços de medicina nuclear do país, que consomem materiais radioativos para fins diagnósticos e terapêuticos. Tem também 3 cíclotrons e 2 radiofarmácias (entre privados e de pesquisa) que produzem radiofármacos para uso nas medicinas nucleares não só de São Paulo, mas em diversos outros municípios brasileiros [43]. No âmbito dos transportes, nela encontram-se um aeroporto nacional (Congonhas) e, em sua região metropolitana, um aeroporto internacional (Guarulhos), nos quais os materiais radioativos embarcam e seguem destino para outros locais.

No decreto municipal ํㅜㄴ 50.446, a prefeitura determina que só poderão realizar o transporte de produtos perigosos as transportadoras inscritas no "Cadastro dos Transportadores de Produtos Perigosos (CTPP)", utilizando-se de veículos que possuam a "Licença Especial de Transporte de Produtos Perigosos (LETPP)" que é emitida pelo Departamento de Operação do Sistema Viário (DSV), da Secretaria Municipal de Transportes. O descumprimento do regulamento implica em 6 penalidades 
possíveis. As que mais impactam para as transportadoras e para o transporte de materiais radioativos são:

1. Multa: estabelecida em um valor de 50 Unidades Financeiras Municipais. (UFM). Em 2017, a UFM foi estabelecida em cento e cinquenta e dois reais ( $R \$$ 152,00) [44]. Assim, a multa vale caso a empresa não possua a licença obtida quando realizado o CTPP e para quando o material radioativo é transportado em um veículo que não possui a LETPP. Em ambos os casos, em 2017, a multa possuía o valor de sete mil e seiscentos reais $(R \$ 7.600,00)$. Em caso de recidiva, a multa pode ser aplicada no dobro do valor. Algumas empresas transportadoras de material radioativo expressaram preferir pagar este valor quando autuadas, por motivos explicados mais a seguir.

2. Retenção do veículo até que seja sanada a irregularidade. Este item apresenta mais uma preocupação, já que, se a retenção ocorrer com o material radioativo ainda no veículo, poderá:

a) expor pessoas não envolvidas no transporte de materiais radioativos durante a retenção em um pátio da prefeitura,

b) se o material for de meia-vida curta, como nos casos de alguns radiofármacos, tem grande possibilidade de ser perdido por causa do decaimento radioativo.

As demais penalidades tratam da suspensão ou cancelamento da licença ou da LETPP.

Porém, o decreto para obtenção do licenciamento exige que seja cadastrada uma empresa (além da transportadora) com Programa de Atendimento a Emergências (PAE). De acordo com a norma CNEN 5.01 o atendimento a emergências deve "ser implementado pelo expedidor e transportador em conjunto". Logo, de acordo com esta normatização, o atendimento a emergências durante 0 transporte é de responsabilidade do transportador e do expedidor, conjuntamente.

A contradição está no cadastro realizado pela prefeitura de São Paulo. Os transportadores relataram que um mesmo CNPJ não pode estar cadastrado como transportador e, ao mesmo tempo, como empresa responsável pelo atendimento à emergência em um único licenciamento. Estranhamente, o próprio decreto estabelece que se $o$ transportador não for habilitado para responder a emergências, deve possuir 
acordo firmado com uma empresa habilitada para o atendimento a emergências relacionadas ao transporte de produtos perigosos, que esteja localizada na região metropolitana de São Paulo. Mas, mesmo assim, não abre espaço para que o transportador forneça o próprio CNPJ na indicação de empresa responsável pela emergência. Além disso, se a transportadora quiser se cadastrar na modalidade de resposta a emergências com um CNPJ diferente, necessitaria de um segundo licenciamento. Além do custo adicional, para este cadastro é necessário que a empresa cumpra requisitos que não viabilizam sua operação ou encarecem demais o custo, como possuir um especialista de proteção radiológica dedicado ao atendimento emergencial $24 \mathrm{~h}$ e possuir guinchos e carros de apoio especializados, que são exigências específicas para este ramo de atuação. Logo, considerando-se as probabilidades de autuação por um agente fiscal, o valor da multa e o investimento necessário para adaptação à norma, alguns transportadores optam por não realizar o licenciamento e pagar a multa.

Outro fator relevante é que o licenciamento é realizado de acordo com o número ONU. Porém, o transporte de material radioativo conta, atualmente, com 26 números diferentes segundo o OIEA [40]. Fica inviável financeiramente ao transportador realizar o licenciamento para cada tipo de produto transportado.

Durante $011^{\circ}$ encontro do Comitê Nacional, enfatizou-se que a normatização estabelecida em nada contribui para o aumento da segurança no transporte de materiais radioativos que ocorre no município, possuindo um caráter puramente arrecadatório. No mesmo encontro, criou-se uma comissão para entrar em contato com o setor do município a fim de expor a situação e viabilizar a resolução da situação. A principal proposta é que os materiais pertencentes a classe 7 sejam isentos desta exigência. Se não todos, ao menos os de uso médico para não haver impacto negativo à saúde pública e privada.

4.3.3.3 Dificuldades entre a legislação do estado de Minas Gerais e demais legislações federais

Muito semelhante ao ocorrido no município de São Paulo, descrito no subcapítulo 4.3.3.2, o estado de Minas Gerais publicou a lei no 22.805 em 29 de dezembro de 2017 [45]. A lei dá medidas a serem tomadas em caso de acidentes no transporte de produtos e resíduos perigosos no território de Minas Gerais, além de 
exigências a serem cumpridas pelos transportadores de produtos perigosos. Apesar de não especificar o modal de transporte, o escopo da lei dá a entender que se aplica somente ao transporte terrestre rodoviário.

Da mesma forma que no município de São Paulo, a lei exige que o transportador mantenha um atendimento a emergências no caso de acidente no transporte de produtos perigosos, podendo ser pela própria empresa ou empresa terceirizada habilitada para $o$ atendimento emergencial [45]. Algumas das exigências são:

a) As ações de emergência devem ser iniciadas pela empresa em até duas horas após a sua ocorrência;

b) Disponibilizar meios para desobstrução da via, remoção do veículo e limpeza em até 4 horas em centros metropolitanos e em até $8 \mathrm{~h}$ nas demais regiões;

c) A descontaminação e limpeza de resíduos deve acontecer em até $24 \mathrm{~h}$ após tomadas as primeiras ações emergenciais;

d) Para este atendimento emergencial, o prestador deve ser pessoa jurídica, cadastrada e licenciada no órgão ambiental estadual, disponibilizando um técnico responsável 24h para o cumprimento do Programa de Atendimento a Emergências (PAE) elaborado,

e) Caso o transportador não cumpra com os requisitos, estes se tornam obrigatoriedade do expedidor do produto perigoso ou do contratante do serviço de transporte, que deverá cumprir os prazos mencionados.

O atendimento emergencial solicitado não é viável e foi discutido no $11^{\circ}$ encontro do Comitê Nacional, em março de 2018, pelos seguintes motivos:

1. Não há empresas especializadas no atendimento a emergências no transporte de material radioativo no país por não ser economicamente viável a manutenção desta empresa e serviço, já que a quantidade de operações de transporte e transportadoras de material radioativo é pequena. As necessidades de operação para este tipo de empresa envolvem a propriedade de guinchos, técnico disponível 24h para atendimento, equipamentos de detecção e descontaminação radioativa (no caso da classe 7), entre outras. 
2. A maioria das empresas que transportam o material não possuem sede ou filiais no estado de Minas Gerais, o que torna inviável o cumprimento dos prazos de atendimento emergencial descritos, especialmente em rodovias isoladas de grandes centros urbanos.

3. Algumas empresas não realizam o transporte com destino ou origem no estado de Minas Gerais, mas utilizam suas vias para o transporte. O licenciamento representa um ônus à empresa que talvez não valha a pena dependendo da rota e da periodicidade com que os veículos passam pelo estado.

Ressalta-se que os atendimentos emergenciais são cumpridos de forma eficiente, não havendo relato de problemas graves ao público ou aos trabalhadores envolvidos por causa do transporte de materiais radioativos no país. O Plano de Atendimento a Emergências já é exigido por outras instituições federais, como a CNEN, a ANTT e o IBAMA. Logo, a referida lei adiciona exigências que não contribuem efetivamente para a segurança no transporte da classe 7 . As exigências anteriormente descritas tornam o transporte mais oneroso e, por vezes, inviável economicamente para o transportador, contribuindo para a indisponibilidade do transporte da classe 7. Este, ainda, representa um único estado da Federação. Se os demais estados tomarem a mesma atitude legislativa, o transportador terá de custear diversos licenciamentos dependendo de sua rota, além dos licenciamentos federais existentes.

Apesar disto, a lei 22.805 do estado de Minas Gerais exige um aspecto de segurança inédito em outras normas que se apresentou interessante e, que na visão do Comitê Nacional, poderia ser incluído nas demais normas ou aproveitado. Este aspecto é a necessidade do contato telefônico em caso de emergências adesivado ou fixado no exterior dos veículos que realizam o transporte de produtos perigosos [45].

\subsubsection{Dificuldade de atracagem em portos brasileiros}

A Agência Nacional de Transportes Aquaviários (ANTAQ) é a responsável pela regulamentação do transporte de produtos perigosos em território nacional por vias aquaviárias, atividade portuária e das instalações localizadas nos portos, com competência atribuída pela lei federal ํo 10.233 de 5 de junho 2001, e posteriormente por sua atualização, lei federal no 12.815 de 5 de junho de 2013 [36, 46]. 
Em sua Resolução 2.239 de 15 de setembro de 2011 [47], a ANTAQ determina que:

A autorização para a atracação de embarcação com produtos da Classe 7 - materiais radioativos deve ser precedida de adoção de medidas de segurança indicadas por pessoa competente em proteção radiológica, que, neste caso, é o Supervisor de Proteção Radiológica (SPR), conforme a Norma 3.03 da CNEN e alterações posteriores.

A norma NN 3.03 referida no trecho foi substituída pela norma NN 7.01 de maio de 2016 e trata da certificação e qualificação de supervisores de proteção radiológica [48].

A presença de um supervisor de proteção radiológica no porto para atracagem do navio em nada contribui para a segurança do transporte. Isso porque $o$ transporte do material radioativo, inclusive determinado pela ANTAQ (que cita as normas da CNEN e do OIEA), pela CNEN e outros órgãos como a Organização Marítima Internacional (International Maritime Organization - IMO), segue requisitos de proteção que dão seguridade ao embalado. Eles incluem procedimentos de fixação, movimentação, sinalização e disposição da carga, além de limitação de doses, uso de blindagens e outros sistemas de proteção limitantes a exposição [4, 19, 47]. Logo, se os requisitos já exigidos forem cumpridos, a presença de um supervisor de proteção radiológica não influencia na seguridade do transporte. E se não cumpridos, o transporte não pode acontecer, sendo que o supervisor não tem papel de fiscalização e também não contribuiria em tal situação.

Por causa desta norma, transportadores e, por vezes, expedidores, têm de dispor de um profissional para acompanhar a atracagem do navio.

\subsubsection{Indisponibilidade de transportadoras}

A indisponibilidade de transportadoras é um dos motivos causadores de recusas e demoras reportados pelo OIEA e pelo Comitê Nacional [1, 7].

O problema de indisponibilidade é agravado por causa das dificuldades com exigências praticadas que, por vezes, inviabilizam as operações ou as encarecem. Empresas não se interessam em realizar o transporte de materiais radioativos por não possuírem o conhecimento suficiente sobre as legislações e considerarem estas dificultosas. Além disso, a percepção de maior risco durante o transporte da classe 7 
em relação às demais classes e a apreensão de custos elevados com o treinamento também contribuem para este fator [7, 25]. Assim, o problema de indisponibilidade pode ser associado à dificuldade do cumprimento das regulamentações nacionais e internacionais vigentes para o transporte e à falta de conhecimento sobre a segurança e as suas exigências. A desburocratização e a harmonização das normas são pontos cruciais para redução dos problemas de recusa e demora, assim como a conscientização sobre o transporte de materiais radioativos e sua segurança.

Para um motorista de cargas perigosas entrevistado, a maior motivação para uma empresa não trabalhar com produtos perigosos, de um modo geral, são as exigências burocráticas. Há mais de 10 anos no ramo, ele explica que não só para o material radioativo, mas para todos os demais produtos perigosos, as exigências são excessivas. O custo para uma transportadora manter um veículo em conformidade com todas as normas vigentes é demasiado e acaba por não compensar, a não ser que haja uma demanda muito grande de trabalho. A empresa em que trabalha, segundo ele, é uma das maiores do Brasil no ramo e encontra-se em grande dificuldade por causa do custo para manutenção dos veículos e adequação às exigências, incluindo as taxas com licenciamento.

\subsubsection{Indisponibilidade do modal aéreo}

Para um funcionário que trabalha no controle de recebimento de materiais radioativos no aeroporto de Guarulhos a indisponibilidade de algumas companhias aéreas em realizar o transporte de materiais radioativos se deve, em partes, pela dimensão das aeronaves. Segundo a legislação vigente [4, 17], uma aeronave de transporte de passageiros deve manter o material radioativo afastado 1 metro do piso onde encontram passageiros por causa do cálculo de IT que considera esta distância, além das exigências da disposição dentro do porão em relação às demais cargas. Algumas estabelecem distâncias entre o material radioativo e filmes não revelados ou outros produtos perigosos, outras dão instruções sobre a fixação do embalado e amarrações. Para o funcionário, a dimensão das aeronaves que realizam voos domésticos para transporte de passageiros nem sempre tem condições de cumprir estas exigências. Assim, a companhia perderia, por exemplo, a possibilidade de transportar outras cargas quando a classe 7 estivesse presente, já que, por vezes, sua disposição dentro da aeronave se torna incompatível com algumas outras mercadorias. 
Um outro entrevistado relatou que uma empresa aérea que transportava regularmente o material radioativo chegou a ficar 3 semanas sem realizar o serviço, alegando falta de espaço nas aeronaves.

Outra questão levantada no $11^{\circ}$ encontro do Comitê Nacional foram as dificuldades com as conexões e mudança da malha aérea durante o transporte de radiofármacos de meia-vida curta. As mudanças diárias e demora entre as conexões podem causar problemas. Além disso, a atividade com que o material tem de ser expedido é muito superior àquela a ser utilizada, já que, por causa do tempo decorrido durante o transporte, o material perde atividade. Um caso preocupante neste cenário é do $18 \mathrm{~F}$-Fluordesoxiglicose, mais conhecido como FDG. O material é utilizado para exames de tomografia por emissão de pósitrons (positron emission tomography - PET) e possui grande demanda de transporte para o nordeste, sendo que sua meia vida física é de aproximadamente 110 minutos. Os problemas com o transporte literalmente interrompem a execução de PET no nordeste quando os cíclotrons locais estão sob manutenção. Relatou-se que certa vez a região ficou um mês sem a possibilidade de realizar o exame, já que seus cíclotrons estavam em manutenção e a malha aérea não tornava viável o transporte em tempo hábil.

Uma empresa aérea, presente naquele momento, explicitou que está aberta a conversar com as transportadoras para verificar alternativas melhores para 0 transporte. Explicou que um dos motivos da demora entre as conexões é a necessidade de parada e conferência fiscal em cada conexão. Sugeriu que, para o caso dos radiofármacos, se verificasse a possibilidade de isenção desta conferência, o que resultaria na agilização do transporte. Infelizmente, não foram adquiridas mais informações sobre este tipo de isenção por esta pesquisa. A informação sobre o procedimento não consta nas normas da ANAC ou outro órgão aéreo, o que indica, provavelmente, que seja um procedimento regulado por normas ou procedimentos internos de operação. Um dos entrevistados afirmou que alguns produtos, dentre eles a propaganda política eleitoral, desfruta desta isenção, sendo passível a análise para aplicação no caso de radiofármacos.

Outro relato recorrente e proveniente de mais de uma entidade entrevistada é o de recusa de embalagens vazias que contiveram material radioativo, especialmente no transporte internacional. $O$ atraso da devolução dessas embalagens gera taxas de 
atraso de entrega e, às vezes, de armazenamento da embalagem vazia no pátio de cargas do aeroporto. O motivo da recusa nunca é bem explicitado, mas a maioria das companhias alega "questões de segurança".

\subsubsection{Indisponibilidade do modal marítimo}

Segundo algumas transportadoras que se utilizam deste modal para auxílio no percurso e de membros de órgãos regulatórios, o modal marítimo é o mais afetado pela indisponibilidade de empresas que realizam o transporte de materiais radioativos. Esse problema já havia sido descrito em 2003, na primeira abordagem sobre recusas e demoras pelo OIEA, como colocado no início do capítulo [1]. Porém, o problema parece só se agravar com o passar do tempo. Segundo os entrevistados, as alianças realizadas entre as transportadoras do modal marítimo reduzem cada vez mais as rotas atendidas e embarcações disponíveis para o transporte, além de aumentarem as exigências internacionais para sua realização.

No relatório do segundo encontro do Comitê, houveram dois relatos de recusa no transporte de material radioativo do Brasil para a China no mesmo ano, um em agosto e outro em outubro de 2010. Em ambos os casos, as transportadoras negaram o transporte por questões de "segurança" [25].

Outro caso, que ocorreu parte por causa da indisponibilidade de transportadoras no setor marítimo e parte por diferenças entre as exigências nacionais e internacionais, foi relatado no $11^{\circ}$ encontro. Comentou-se que para transportar uma carga do Brasil para a Europa havia apenas uma transportadora disponível no início de 2018, o que faz com que o frete fique extremamente caro por causa da exclusividade daquela empresa. Uma alteração na rota marítima da transportadora fez com que de 4 a 5 containers contendo material radioativo ficassem, aproximadamente, 3 meses parados aguardando o embarque. Isso porque um dos portos de atracação do navio exigiu que houvesse um seguro especial para a classe 7. Porém, no Brasil, a classe 7 (radioativos) e a classe 1 (explosivos) não possuem empresas especializadas em seguro de transporte desses materiais. No caso da classe 1, é porque possui seu controle exclusivo pelo exército brasileiro [49]. No caso da classe 7, a demanda nacional de transporte de material radioativo e a necessidade do seguro em casos regionais ou internacionais são muito pequenas, não atraindo interessados em criar uma empresa seguradora, já que esta não teria demanda que compensasse os gastos. 
Ainda assim, a empresa que precisava enviar o material para o comprador teve que contratar um seguro fornecido por uma empresa de outro país para cumprir a exigência daquele único porto de atracagem. Se não cumprida, o navio não poderia realizar a parada no porto, prejudicando o transporte de outras mercadorias. Cada container do material custava em torno de 800 mil dólares e, por causa deste problema no transporte, a empresa quase perdeu seu cliente comprador, o que resultaria em um prejuízo estimado de 4 milhões de dólares. O problema ocorreu por falta de conhecimento dos operadores logísticos da transportadora marítima, que não identificaram que a mudança de rota poderia causar estes impactos no transporte da classe 7 . A empresa expedidora do material e responsável pelos containers explicitou que o material radioativo é sempre tratado como potencial risco de perda de clientes, já que o material radioativo enfrenta muitos problemas com o transporte e com outros aspectos legais e pode, durante as operações, prejudicar a comercialização de outras mercadorias.

Foi ressaltado que a CNEN, conjuntamente com algumas empresas, vem mapeando os portos internacionais para verificar as exigências nas operações de ancoragem, mudança de carga e descarga de material radioativo a fim de averiguar quais os possíveis problemas a serem enfrentados. Uma empresa relatou que, por vezes, fica inviável realizar o transporte por via marítima porque alguns portos no exterior não permitem a presença de material radioativo. Logo, se o navio possui parada no porto, não fica apto a transportar o material, limitando o número de rotas possíveis.

A imagem da página 66 demonstra a redução de empresas que realizam o transporte marítimo de materiais radioativos ao longo dos anos. A fonte que cedeu as informações contidas da imagem preferiu não ser divulgada, mas esclarece que as informações já foram, inclusive, apresentadas em encontros internacionais sobre o assunto. Outro relato, dado por uma transportadora que se utiliza do modal marítimo, conta que há vários problemas enfrentados no processo de cabotagem.

A cabotagem é o procedimento de transporte de cargas pela costa nacional utilizando-se da via marítima. O Brasil possui $7.491 \mathrm{~km}$ de costa pelos quais é possível transportar cargas da região sul até a região nordeste, podendo-se, ainda, adentrar a região norte por meio do rio Amazonas [50]. Assim, representa uma rota comercial importante e fornece alternativa à utilização dos modais terrestre e aéreo. 
Atualmente, somente uma empresa realiza 0 transporte de material radioativo nesta rota. Além de encarecer o custo do frete por causa da falta de concorrência, isto faz com que o transporte fique limitado às rotas e disponibilidade de embarcações de uma única empresa. Durante entrevista, uma empresa de transporte informou que para realizar a cabotagem no Brasil são necessários de 2 a 3 meses de antecedência e preparo de documentações. Isso tem como causa a burocracia envolvida, que demanda diversas autorizações e liberações de transporte por diferentes órgãos antes que a operação possa ocorrer. Ainda há o risco de, se alguma delas for barrada ou não ser concedida no prazo esperado, perde-se a embarcação disponível que faria a rota, adiando ainda mais a operação de transporte. 
Figura 3 - Redução de transportadoras marítimas ao longo dos anos
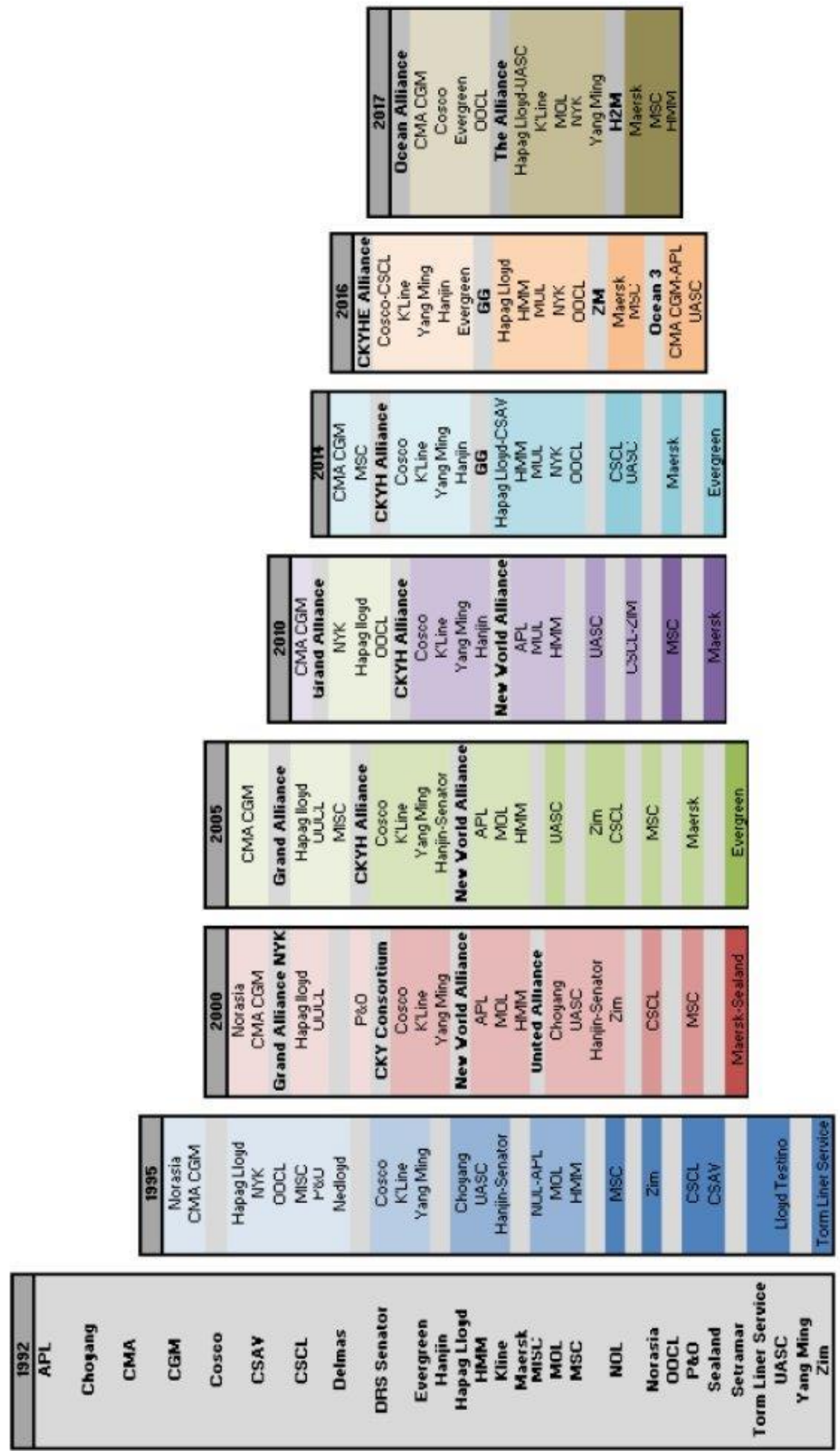

Fonte: anônima. 


\subsubsection{Indisponibilidade no modal terrestre}

Ao decorrer desta pesquisa não houveram relatos sobre a indisponibilidade de transportadoras no modal terrestre. Os gráficos 5 e 6 mostram que este é o modal que enfrentam menos problemas, de acordo com os entrevistados.

\subsubsection{Falta de conhecimento sobre o transporte de materiais radioativos}

A falta de conhecimento sobre a segurança no transporte de materiais radioativos e, consequentemente, o medo causado pela percepção de risco da radiação ionizante, foram associados ao problema com o transporte de materiais radioativos [1, 25]. Isto atinge, principalmente, pessoas que não trabalham com o material radioativo exclusivamente, ou seja, não representam uma empresa especializada neste tipo de transporte, um fabricante ou expedidor, mas possuem um papel importante no momento de seu transporte. É o caso, por exemplo, de pilotos de aeronaves e comandantes de navios, fiscais de importação e exportação nos portos e aeroportos, fiscais e agentes de trânsito nas rodovias, assistentes de embarque e carregamento de cargas, entre outros profissionais.

Apesar desta temeridade, o OIEA ressalta que por décadas nunca houve um acidente com material radioativo durante o transporte que trouxesse consequências graves à saúde humana, ao meio-ambiente ou à economia [1].

No terceiro encontro do Comitê, em setembro de 2011, um comandante explicitou que já negou realizar o transporte de material radioativo em seu navio, já que não sabia avaliar efetivamente o risco que ele e seus trabalhadores corriam ao transportar este tipo de carga. Informou que "quase nada é feito no sentido de proporcionar às pessoas que trabalham a bordo informações sobre o que estão carregando" [51]. Assim, a falta de instrução destes profissionais afeta o transporte de materiais radioativos. As informações que recebem sobre o material radioativo e seu transporte, como não são diretamente ligados a empresas especializadas na classe 7 , se resumem àquelas recebidas pela população geral e nos cursos para transporte de cargas perigosas exigidos em legislação. Uma análise destas informações é dada nos subcapítulos 4.3.5.1 e 4.3.5.2 deste trabalho. 
Durante $11^{\circ}$ encontro do Comitê Nacional, um dos participantes, que presta treinamento para transporte de materiais radioativos há alguns anos, explicitou que os pilotos geralmente possuem uma perspectiva muito errônea sobre a classe 7 e sempre questionavam sobre a segurança no transporte. Explica que o trabalho de educação e sensibilização é contínuo e acontece com cada novo piloto treinado e que, por sua experiência, a percepção de risco vem melhorando nos últimos anos.

Durante entrevista com um oficial do exército, responsável pelo transporte de cargas perigosas da classe 1, explosivos, foi comentado que a percepção de risco na instituição é diferenciada por causa do treinamento fornecido. Ao entrarem para a instituição, os soldados recebem o treinamento com diversos tipos de armamento e se habituam, desde seu ingresso, com a manipulação destes materiais perigosos. Um dos motivos de sucesso para o efetivo treinamento e cumprimento dos padrões de segurança é que a instrução dos soldados é realizada somente por oficiais especialistas, que possuem experiência na manipulação e formação adequada para um tipo específico de armamento ou munição. A instrução dos soldados não pode, por exemplo, ser submetida a um integrante não que não seja oficial especialista. $O$ oficial entrevistado, por estar habituado com a manipulação de outros produtos perigosos, informou que não pensa que o material radioativo possa apresentar maiores riscos do que as outras classes. Inclusive, imagina que a segurança seja mais intensa que em outras modalidades e que, se tivesse que trabalhar com este tipo de material, não teria objeções ou hesitação. Isto demonstra que a educação e a formação influem diretamente na percepção de risco durante o transporte de produtos perigosos, incluindo o material radioativo. Apesar de não operar com a classe 7, o oficial não apresentaria objeções pois foi instruído, de maneira sólida, que o transporte de produtos perigosos é seguro se seguidos os procedimentos corretos.

Um funcionário responsável pelo despacho da carga de material radioativo de uma empresa aérea que opera no aeroporto de Guarulhos, São Paulo, informou que entre os carregadores há um medo constante na manipulação dos embalados que possuem o símbolo de material radioativo. Conta que, por vezes, os carregadores ficam hesitantes em manipular a carga. A empresa transporta, principalmente, insumos para fabricação de radiofármacos. Quando questionado sobre o problema com pilotos, este informou que nos últimos anos, lembra-se de ter ocorrido somente 1 recusa por ano, no máximo. Uma delas, mais recente, aconteceu pela recusa em transportar um 
embalado vazio, no caso, uma blindagem, que retornava ao país de origem. A embalagem teve que ficar abrigada em um galpão enquanto aguardava liberação para outro voo, gerando o custo de armazenamento por um período de $24 \mathrm{~h}$.

Para sua formação, o agente informa que é necessário realizar um curso exigido pela ANAC para transporte aéreo de cargas perigosas. O curso é oferecido por escolas particulares, porém, seu conteúdo é fiscalizado e autorizado pela ANAC. O funcionário informou que o curso teve duração de dois meses, sendo que um mês foi dedicado somente à classe 7 por causa da complexidade das legislações e exigências envolvidas. Informa que não possui receio de trabalhar com a manipulação destes materiais para transporte, e que o curso ofereceu base suficiente para realizar o trabalho sem medo.

Durante esta pesquisa, diversos entrevistados, dentre empresas transportadoras, expedidoras e órgãos regulatórios, relataram a seguinte situação: mesmo sem a presença do medo de radiação, a falta de conhecimento sobre as especificações das normas regulatórias gera demoras e recusas. Agentes fiscais em rodovias, portos e aeroportos que atuam na recepção, expedição e liberação dos documentos utilizados no transporte de materiais radioativos com frequência confundem exigências como sinalização, classificação de materiais e preenchimento de documentos, retendo o material ou não autorizando seu transporte. Esta situação tem grande ocorrência, tendo sido citada por todas as transportadoras e empresas expedidoras entrevistadas. Tal problema ocorre principalmente por:

a) Falta de conhecimento específico dos agentes fiscais, que deveriam tê-lo adquirido durante o treinamento para a função e/ou suas atualizações;

b) Numerosas normas regulatórias para um mesmo assunto, dificultando a interpretação da legislação e, assim, sua aplicação.

Sabe-se que os textos presentes em normas exigem um vocabulário apropriado, que expresse as ideias e conceitos com clareza, evitando assim duplos sentidos ou interpretações ambíguas, que podem gerar problemas. Para atingir isto, o vocabulário pode se tornar complexo, além de conter especificidades inerentes a área do conhecimento. Logo, o indivíduo que irá interpretar as normas deve conseguir compreender o texto e suas particularidades. Porém, se considerarmos o conceito de analfabetismo funcional, que seria todas as pessoas com menos de quatro séries de 
estudo concluídas, o Brasil possui em torno de 30 milhões de analfabetos funcionais em 2017, equivalente a aproximadamente 15\% da população, considerando as pessoas com 15 anos ou mais. O Ministério da Educação informa que, apesar de passar mais de oito anos na escola, o analfabeto funcional não consegue avançar as séries básicas por falta do ensino de qualidade [52].

Noticiado em 2016 pela revista época, o Programa de Avaliação Internacional de Estudantes (Program for International Student Assesment - PISA) mostrou que o Brasil possui a capacidade de leitura e interpretação de texto abaixo do nível mundial. Além disso, 51\% dos estudantes está abaixo do nível 2 do teste, considerado o necessário para que o estudante consiga exercer sua cidadania [53].

Diante deste cenário, os diversos trabalhadores envolvidos no transporte de material radioativo dificilmente possuirão capacidade para interpretar as normas corretamente. Mesmo os mais alfabetizados podem encontrar dificuldades já que, para adequar-se às normas, devem ser capazes de interpretar, comparar e executar informações de diversos documentos.

\subsubsection{A educação nacional e o desafio da divulgação de informação}

A maioria da população desconhece a radiação ionizante e suas aplicações, associando-a principalmente com o câncer, as bombas atômicas e os acidentes nucleares e radiológicos. A falta de conhecimento básico sobre a radiação ionizante e proteção radiológica pode causar medo, ansiedade e pânico, que foram observados, por exemplo, durante o acidente radiológico de Goiânia [9]. No Brasil o ensino de física é realizado durante o ensino médio, que faz parte do ensino básico nacional, e prevê somente 2 horas aula semanais para todos os assuntos a serem abordados. Além do que, apesar de haver programas de incentivo e metas estabelecidas para formação continuada de professores, boa parte não está capacitada para abordar o tema [54].

A respeito das radiações ionizantes e suas aplicações, estão incluídos na base nacional comum curricular os seguintes temas: fusão e fissão nuclear, efeitos biológicos das radiações ionizantes e produção de armamentos nucleares. A produção de energia por fissão pode ser abordada no ensino na matriz energética brasileira. Não consta no documento o ensino de demais assuntos como a aplicação das radiações ionizantes para outros fins, como na saúde, na indústria e na agricultura. Com estes 
temas de aula, visam capacitar o aluno e desenvolver sua habilidade de "utilizar o conhecimento sobre as radiações e suas origens para avaliar as potencialidades e os riscos de sua aplicação em equipamentos de uso cotidiano, na saúde, na indústria e na geração de energia elétrica" [55]. Verificando os temas propostos, percebe-se que os assuntos a serem abordados no ensino médio não favorecem a formação de uma visão favorável para a energia nuclear. Basicamente, todo brasileiro concluirá o ensino médio com uma vaga noção do funcionamento das radiações ionizantes e, provavelmente, uma visão extremamente limitada e tendenciosa de suas aplicações, além de uma análise de risco comprometida.

O desenvolvimento do tema dependerá, principalmente, do professor. A forma como o assunto é abordado pode levar o aluno a ver as aplicações das radiações como algo seguro e praticável ou até perigoso e abominável. Como explicitado pelo depoimento do oficial do exército neste capítulo, a instrução do risco por alguém que tenha experiência ou possui conhecimento sólido no assunto é um dos fatores cruciais para uma formação bem-sucedida. No caso do ensino médio, este conteúdo é ministrado por físicos licenciados, idealmente. Mas pode ser ministrado por professores de matérias correlatas caso haja carência do profissional específico. Neste caso, poderá ser ministrada por professor de química ou matemática.

Esta pesquisa realizou uma entrevista com dois professores de física da cidade de São Paulo, ambos atuantes no ensino médio público e privado. As informações cedidas foram:

a) Dos cinco sistemas de ensino com que trabalharam, somente um possuía em suas apostilas algo referente a radiação ionizante. Ainda assim, era uma explicação breve sobre energia nuclear. Na maioria das turmas em que lecionaram, o tema não foi abordado por não estar na grade curricular do ensino médio naquela época (diferente do descrito na nova grade curricular citada anteriormente), ou não estar contemplado no plano de ensino da instituição, sendo classificado como física moderna. Em algumas situações, os professores abordaram o tema em mostras culturais ou em trabalhos;

b) Ambos professores abordam em sala outros usos da radiação ionizante que não a produção de energia elétrica, incitando os alunos a pesquisarem sobre o tema apesar de este não estar na grade curricular de ensino; 
c) Ambos informam que diversos colegas de trabalho sequer abordam o tema, porque, primeiramente, não há tempo para abordá-lo, já que se deve cumprir o conteúdo das apostilas fornecidas e, segundamente, não conhecem o assunto, pois são professores de matérias como matemática e ciências que lecionam física para complementar a carga horária;

d) Apesar de constar na matriz no novo ensino médio, os temas de fusão e fissão nuclear dificilmente encontraria profissionais capacitados para lecioná-los no ensino médio.

Um estudo publicado em 2017 evidenciou os mesmos problemas relatados acima, abordando mais extensamente o assunto. Nele, concluiu-se que existe uma fobia acerca da radiação ionizante em alunos brasileiros. Também, que as escolas necessitam de apoio para desmistificar o assunto e abordá-lo no ensino médio, dando como solução a aproximação entre escola e instituições que empregam tecnologias que usam radiações ionizantes e profissionais capacitados no tema, promovendo palestras, cursos e oficinas para os alunos e para os professores [54].

Isto impacta, também, no processo de formação dos profissionais que lidarão com o transporte de material radioativo. Ao ingressarem na área, necessitarão de uma formação que explique não só o inerente ao transporte, mas também o que é radiação, quais são suas aplicações, o risco verdadeiro fornecido pelos produtos transportados e os meios de proteção. Ou seja, necessitarão do conhecimento básico sobre a radiação. Além disto, o interesse da população de ingressar neste setor ou contribuir para seu desenvolvimento é diretamente influenciado por sua percepção do tema, que, como exposto, é vago e tendencioso.

4.3.5.2 Qualificação profissional para o transporte de materiais radioativos

A exigência da formação para o transporte de produtos perigosos em âmbito nacional depende, principalmente, do modal de transporte. A norma CNEN 5.01 estabelece que os trabalhadores envolvidos no transporte devem:

Ser informados sobre os riscos radiológicos associados ao transporte $e$ estar adequadamente treinados, na medida do necessário e conforme o tipo de trabalho e as precauções a serem observadas, para a execução de suas tarefas em condições de segurança. 
Porém, não define o que é estar "adequadamente treinado", nem quais as situações de necessidade. Assim, as exigências para este tipo de treinamento são muito vagas, ficando seu entendimento a cargo da empresa de transporte, do expedidor, etc. Não especifica, por exemplo, quais trabalhadores devem ser treinados ou não, mas aponta que dependerá do tipo de trabalho.

No caso dos transportes terrestres, têm-se a exigência de curso para os motoristas, conhecido como curso de movimentação e operação de produtos perigosos (MOPP), estabelecido pela normatização 168 do CONTRAN em 2004 [15]. A normatização também abrange a grade curricular do curso. A Tabela 7 mostra a estruturação vigente para o curso MOPP e uma análise do conteúdo na aplicação do transporte de materiais radioativos.

Tabela 7 - Estruturação do curso MOPP e considerações sobre o conteúdo

(continua)

\begin{tabular}{|c|c|c|c|}
\hline $\begin{array}{l}\text { Módulo } \\
\text { do } \\
\text { Curso[a] }\end{array}$ & $\begin{array}{l}\text { Tema do Módulo e } \\
\text { conteúdo[a] }\end{array}$ & $\begin{array}{c}\text { Horas } \\
\text { aulas } \\
\text { exigidas }^{[a]}\end{array}$ & $\begin{array}{c}\text { Consideração deste } \\
\text { trabalho }^{[\mathrm{b}]}\end{array}$ \\
\hline I & $\begin{array}{l}\text { Legislação de Trânsito: inclui } \\
\text { as legislações de todas as } \\
\text { modalidades de materiais } \\
\text { perigosos para transporte, } \\
\text { responsabilidades do } \\
\text { condutor, documentação e } \\
\text { simbologia. Também trata } \\
\text { dos aspectos civis gerais } \\
\text { para transportes. }\end{array}$ & 10 horas & $\begin{array}{l}\text { Considerado que o motorista } \\
\text { deve ser habilitado para } \\
\text { realização do curso, a carga } \\
\text { horária é compatível para } \\
\text { revisão de obrigações e } \\
\text { aspectos gerais na } \\
\text { condução de veículos. } \\
\text { Porém, insuficiente no caso } \\
\text { da legislação de produtos } \\
\text { perigosos, já que esta é } \\
\text { muito extensa. }\end{array}$ \\
\hline
\end{tabular}


Tabela 7 - Estruturação do curso MOPP e considerações sobre o conteúdo

(continuação)

\begin{tabular}{|c|c|c|c|}
\hline II & $\begin{array}{l}\text { Direção Defensiva: abrange } \\
\text { a prevenção de acidentes e } \\
\text { procedimentos a serem } \\
\text { seguidos no pós-acidente. }\end{array}$ & 15 horas & $\begin{array}{l}\text { Competência inerente a todo } \\
\text { condutor, não havendo } \\
\text { impacto específico no } \\
\text { transporte de materiais } \\
\text { radioativos. }\end{array}$ \\
\hline III & $\begin{array}{l}\text { Noções de Primeiros } \\
\text { Socorros, Respeito ao Meio } \\
\text { Ambiente e Prevenção de } \\
\text { Incêndios }\end{array}$ & 15 horas & $\begin{array}{l}\text { No caso do transporte de } \\
\text { materiais radioativos, o } \\
\text { motorista toma ações breves } \\
\text { em caso de acidentes, como } \\
\text { isolamento de área, } \\
\text { acionando, posteriormente, } \\
\text { a proteção radiológica. } \\
\text { Assim, mesmo que o módulo } \\
\text { abranja conteúdo } \\
\text { procedimentos de outras } \\
\text { categorias, para o motorista, } \\
\text { a carga horária é suficiente. }\end{array}$ \\
\hline IV & $\begin{array}{l}\text { Movimentação de Produtos } \\
\text { Perigosos: Abrange as } \\
\text { legislações específicas de } \\
\text { todas as classes de produtos } \\
\text { perigosos, incluindo a Classe } \\
\text { 7. Também materiais que } \\
\text { oferecem múltiplos riscos e } \\
\text { procedimentos em casos de } \\
\text { emergência. }\end{array}$ & 15 horas & $\begin{array}{l}\text { Carga horária insuficiente } \\
\text { para abranger, de forma } \\
\text { sólida, todas as } \\
\text { regulamentações vigentes } \\
\text { para o transporte de todas } \\
\text { as classes de produtos } \\
\text { perigosos. Considerando } 8 \\
\text { classes de produtos } \\
\text { perigosos, tería-se a média } \\
\text { de } 112,5 \text { minutos ( } \approx 1,8 \mathrm{~h}) \text { de } \\
\text { aula para cada classe. } \\
\text { Como exposto no item } 4.3 .2 \text {, } \\
\text { a normatização para a } \\
\text { classe } 7 \text { extensa e } \\
\text { demandaria de maior tempo } \\
\text { para a aprendizagem. }\end{array}$ \\
\hline
\end{tabular}

Fontes: [a] Conselho Nacional de Trânsito, Resolução 168 de 2004. [b] Autor da dissertação. 
Durante os encontros do Comitê, por diversas vezes, foi comentado que este curso não fornece base suficiente para realizar o transporte de materiais radioativos. Assim, uma formação complementar se faz necessária. No caso das empresas transportadoras, algumas relataram que realizam por conta própria o treinamento de seus funcionários. Os motoristas e outros operadores de carga recebem instruções na própria empresa, o que melhora muito a compreensão das exigências para o transporte de materiais radioativos e evita problemas que podem ser causados por estes trabalhadores. Isso nos dá visão para duas dificuldades. A primeira, é que o transportador de materiais radioativos possui custos adicionais com o treinamento de pessoal, o que pode representar a redução de interesse das empresas em trabalhar neste ramo. A segunda, é que os demais profissionais que não estão ligados diretamente a empresas que transportam ou fabricam/expedem o material radioativo, mas participam de alguma forma no processo de transporte, acabam não recebendo a formação complementar, já que não necessitam dela diretamente. Assim, sua compreensão das exigências e da segurança no transporte da classe 7 não corresponde à realidade e pode gerar problemas, como exposto no início deste capítulo.

Um motorista que possui o curso MOPP e trabalha com o transporte de cargas perigosas há 12 anos, informou em entrevista que o curso que realizou não especifica nada além do símbolo do material radioativo. Que entre os motoristas, de modo geral, sabe-se que quem quiser ingressar no transporte da classe 7 deverá realizar um treinamento a parte. Logo, apesar de cumprir com a exigência do Código de Trânsito Brasileiro (CTB) [16], o curso MOPP não contribui, praticamente, para a formação de um motorista ou outro profissional que lidará com material radioativo.

O curso MOPP é exigido para os motoristas, especificamente, mas não para agentes ficais de trânsito, por exemplo.

Os fiscais de trânsito podem representar funcionários dos órgãos de trânsito municipais ou estaduais, de um órgão federal (como a ANTT e o IBAMA) ou das polícias, neste caso, polícia militar, polícia civil e polícia federal. Logo, o treinamento difere de acordo com a instituição a que o fiscal está atrelado. Esta pesquisa não encontrou documentos que indicassem qual o treinamento necessário ou aplicado para estes profissionais. Um entrevistado, membro do Departamento de Trânsito da Polícia 
Militar de São Paulo, alega que para realizar este tipo de fiscalização é necessário que se cumpra um treinamento no Comando de Policiamento de Trânsito (CPTRAN), denominado Curso de Fiscalização de Produtos Perigosos, mas não sabe dizer se o mesmo curso é válido ou aplicado aos agentes da Companhia de Engenharia de Trafego (CET), órgão estadual que também atua na fiscalização por via terrestre.

No transporte aéreo, a RBAC 175 da ANAC [17] exige que o treinamento ocorra por uma instituição credenciada junto ao órgão. $O$ treinamento difere de acordo com o cargo ocupado pelo funcionário e varia de $8 \mathrm{~h}$ a $40 \mathrm{~h}$. São 12 categorias entre membros da tripulação da aeronave, operadores de carga, expedidores, funcionários que realizam a aceitação e despacho dos materiais, funcionários de segurança e funcionários de atendimento a passageiros. $O$ documento que descreve as categorias, a carga horária de treinamento e o conteúdo programático sugerido é Instrução Suplementar (IS) no 175-002 [56]. O Apêndice A e o Apêndice $C$ da referida IS encontram-se no anexo (ANEXO 2 e ANEXO 3, respectivamente) deste trabalho. $O$ Apêndice $A$ (ANEXO 2) apresenta a grade curricular sugerida no treinamento e possui a descrição das categorias de funcionários. O Apêndice C (ANEXO 3) apresenta o conteúdo programático sugerido para cada uma das matérias da grade curricular, entre normas nacionais e instruções técnicas internacionais.

A Tabela 8 foi retirada da IS no 175-002, e apresenta a carga horária mínima para os cursos de formação de acordo com a categoria profissional [56].

Tabela 8 - Carga horária mínima dos cursos para formação no transporte de materiais perigosos no modal aéreo

\begin{tabular}{c|c|c|c|}
\hline Categorias & $\mathbf{6}$ & $\mathbf{1 , 2 , 3}$ & $\mathbf{4 , 5 , 7 , 8 , 9 , 1 0 , 1 1 , 1 2 , 1 3 , 1 4 , 1 5 , 1 6 , 1 7}$ \\
\hline Curso Inicial & $40 \mathrm{~h}$ & $32 \mathrm{~h}$ & $8 \mathrm{~h}$ \\
\hline Curso Periódico & $24 \mathrm{~h}$ & $16 \mathrm{~h}$ & $4 \mathrm{~h}$ \\
\hline
\end{tabular}

Fonte: Agência Nacional de Aviação Civil, Instrução Suplementar no 175-002.

As categorias de funcionários $n^{\circ} 13,14,15,16$ e 17 correspondem a operadores aéreos não autorizados a transportar produtos perigosos como carga ou mala postal. Fazem parte deste grupo funcionários de atendimento a passageiros, comissários de bordo, pilotos e outros que não irão transportar produto perigoso. Assim, não estão relacionados ao objeto de estudo deste trabalho. 
Verificando a tabela acima, percebe-se que a maior carga horária é dedicada às categorias 1, 2, 3 e 6, que são:

1 - Expedidores e pessoas que assumem as responsabilidades dos expedidores, incluindo os funcionários dos operadores aéreos que atuam como expedidor de produto classificado como artigo perigoso.

2 - Pessoas responsáveis pelo preparo da embalagem com artigo perigoso embalador.

3 - Funcionários das agências de carga aérea envolvidos no processamento de artigos perigosos.

6 - Funcionários dos operadores aéreos e agentes de manuseio em solo que realizam procedimento de aceitação de artigos perigosos.

O cronograma, ANEXO 3 deste trabalho, deixa como nota que:

Os assuntos listados na tabela anterior devem contemplar especificidades necessárias para a atuação dos funcionários em treinamento. Exemplo: Para operadores aéreos que transportem material radioativo, bateria de íons de lítio e substância biológica, Categoria $B$, os itens do conteúdo programático dos treinamentos providos a seus funcionários devem contemplar esses assuntos.

Para as categorias com maior carga horária citadas acima, o cronograma de ensino encontra-se muito completo para as normas expedidas por autoridades do setor aéreo, como as publicadas pela ANAC e pela IATA. Porém, não abrangem a comparação ou sequer citam no documento a presença de normas como as da CNEN. Isso pode fazer com que os responsáveis pela aceitação do material perigoso sequer conheçam a existência de normas complementares que estarão presentes durante o transporte. São treinados estritamente para a obediência e conferência das normas de autoridades aéreas que, como visto ao longo deste trabalho, podem estar conflitantes com outras normas.

Ressalta-se que isso não insinua que o transportador aéreo ou a autoridade aérea devam desconsiderar as exigências de suas normas como forma de amenização ao problema de incompatibilidade. Mas sim, que outros aspectos de segurança, sinalização e disposição dos produtos perigosos desconhecidos pelos funcionários vão estar presentes durante o transporte, dando abertura a problemas. Como exemplo, sabe-se que as normas aéreas para o transporte de produtos perigosos informam que 
os requisitos exigidos por outras instituições devem ser cumpridos, chegando a citar a CNEN em alguns documentos. Porém, se seguido o conteúdo programático apresentado, o curso não abordará as normas da CNEN ou de qualquer outra instituição que não as do modal aéreo. Assim, o conhecimento das exigências dessas normas fica em aberto e dependerá de o instrutor do curso abordá-las ou não.

Durante $011^{\circ}$ encontro do Comitê Nacional, foi relatado por um participante que ministra cursos como o acima descrito que um trabalho de sensibilização sobre o transporte de material radioativo vem sendo feito com pilotos e demais trabalhadores envolvidos, mostrando resultados positivos e que auxiliam a mitigar os problemas de recusa e demora. Porém, não há certeza que um profissional como este estará presente em todas as instituições que oferecem o treinamento. Atualmente, 44 instituições de ensino são credenciadas pela ANAC para fornecer os cursos. A presença de profissionais com conhecimento técnico de outras normas de transporte de materiais radioativos ou com uma percepção favorável a respeito do transporte da classe 7 em todas estas instituições é pouco provável [57].

No setor marítimo, o treinamento para o transporte de cargas perigosas é descrito no Programa de Ensino Profissional Marítimo para Aquaviários (PREPOM). O curso citado no documento é o de Operação com Cargas Perigosas no Trabalho Aquaviário (EOCA). O curso destina-se a "capacitar o Aquaviário quanto aos conhecimentos básicos sobre as atividades pertencentes ao manuseio e transporte de cargas perigosas, em conformidade com o Código Marítimo Internacional para Transporte de Mercadorias Perigosas (IMDG Code)". Para realizar o curso, o indivíduo deve ser marítimo com habilitação a partir do nível 5, determinado pela marinha de acordo com o cargo. O curso tem uma carga horária de 26 horas, sendo 24 horas de aula teórica e 2 horas de atividade extraclasse [58].

A análise da grade curricular descrita no site de uma empresa habilitada para ministrar o curso EOCA se encontra na Tabela 9.

Nota-se que a grade curricular contida na Tabela 9 não seria suficiente para abordar todos os aspectos do transporte da classe 7, especialmente se for aplicado a um agente fiscal. Para funcionários que realizarão somente a estivagem da carga ou sua aceitação superficial (sem análise da conformidade com a legislação), o conteúdo 
mostra-se parcialmente satisfatório, mas com necessidade de mais tempo para o treinamento em estivagem.

Tabela 9 - Grade curricular para o EOCA

(continua)

\begin{tabular}{|c|c|c|}
\hline $\begin{array}{l}\text { Horas } \\
\text { aula[a] }\end{array}$ & Conteúdo[a] & $\begin{array}{c}\text { Considerações deste } \\
\text { trabalho[b] }\end{array}$ \\
\hline $4 h$ & Familiarização e reconhecimento & $\begin{array}{l}\text { No caso do reconhecimento de } \\
\text { símbolos e familiarização com } \\
\text { as sinalizações, a carga horária } \\
\text { é adequada. }\end{array}$ \\
\hline $2 \mathrm{~h}$ & $\begin{array}{l}\text { Listagem de substâncias perigosas } \\
\text { do volume } 2 \text { do código IMDG }\end{array}$ & $\begin{array}{l}\text { Para simples listagem de } \\
\text { substâncias perigosas e suas } \\
\text { subclasses, a carga horária é } \\
\text { adequada. }\end{array}$ \\
\hline $3 h$ & $\begin{array}{l}\text { Requisitos gerais para as } \\
\text { embalagens que transportam } \\
\text { substâncias perigosas }\end{array}$ & $\begin{array}{l}\text { O título é ambíguo e pode } \\
\text { abordar diferentes assuntos, } \\
\text { desde documentação } \\
\text { necessária a constituição da } \\
\text { embalagem. Neste quesito, a } \\
\text { carga horária não é suficiente } \\
\text { de acordo como o tema } \\
\text { específico a ser abordado. }\end{array}$ \\
\hline $3 h$ & $\begin{array}{l}\text { Construção e testes de } \\
\text { embalagens }\end{array}$ & $\begin{array}{l}\text { Este tema pode assegurar a } \\
\text { percepção correta sobre a } \\
\text { segurança do transporte. A } \\
\text { carga horária parece suficiente } \\
\text { para um esclarecimento breve. }\end{array}$ \\
\hline
\end{tabular}


Tabela 9 - Grade curricular para o EOCA

(continuação)

3h Estivagem

A estivagem compreende a ação de dispor a carga. Neste quesito, 3 horas parecem insuficientes para abordar todos os requisitos para produtos perigosos. A classe 7 , por exemplo, possui regras de disposição específicas de acordo com o IT e com a presença de outros produtos perigosos que dificilmente serão esclarecidos em 3 horas de curso, considerando-se que há mais classes a serem abordadas.

4h Instrumentos relevantes previstos A emenda 34 e o capítulo 1.3 no código IMDG emenda 34 e dão disposições gerais sobre o capítulo 1.3 treinamento e as responsabilidades profissionais de acordo com o cargo pretendido. 4 horas são suficientes para entende-los, porém, em sua redação já se percebe que outras informações e estudo de normas serão necessários para o transporte correto e bemsucedido da classe 7 .

[a] conteúdo fornecido por empresa ministrante do curso em seu sítio eletrônico.

[b] observações feitas pelo pesquisador deste trabalho.

Fonte: Empresa Shelter. Curso EOCA. Disponível em <https://www.sheltermar.com.br/cursos/eoca/>. Acessado em 04/03/2019. 
Outros treinamentos são exigidos pela Marinha de acordo com o posto a ser alcançado. Todos eles são baseados nos requisitos contidos no código IMDG. Este, por sua vez, especifica que todos os envolvidos no transporte de produtos perigosos devem ser treinados de acordo com suas funções [19]. A tabela traduzida contida no IMDG sobre os conhecimentos específicos inerentes e recomendados a um cargo encontra-se em anexo (ANEXO 4) desta dissertação. Sobre ela, pode-se fazer as seguintes considerações:

a) Se seguida à risca pelo instrutor, fornece condições suficientes para o transporte bem-sucedido da classe 7. Apesar de não detalhados, os conhecimentos descritos na tabela incluem a análise de normas nacionais e de autoridades competentes, o que incluiria as normas de todos os organismos citados ao longo deste trabalho, como CNEN, ANTT e IBAMA;

b) Exigências locais, exigências dos portos e regras nacionais de transporte são sugeridas para quem transporta o produto perigoso, manuseia o produto perigoso durante $o$ transporte, aceita e oferece os produtos perigosos para transporte e fiscaliza o cumprimento das normas. Este é, sem dúvida, um conteúdo bem extenso contando-se somente com a classe 7. Nesta categoria o curso necessitaria de pelo menos 40 horas para conseguir abranger todas as normatizações vigentes e suas respectivas interpretações. Porém, dificilmente um curso exigido pela marinha terá tal duração para uma única classe. Esta afirmação pode ser baseada na grade curricular do curso EOCA, apresentada na Tabela 8;

c) A classe 7 representa uma porção pequena de todo o transporte de produtos perigosos por via aquaviária. Cursos específicos para ela ou com carga horária dedicada não se apresentam economicamente interessantes ou viáveis para o transportador ou armador. Assim, problemas de recusa ou demora são mais propensos a acontecer;

d) Isso também explica a pequena quantidade de transportadoras de material radioativo no modal marítimo, descrita detalhadamente no subcapítulo 4.2.4.2, já que o treinamento segundo o IMDG é exigido pela Marinha para que a transportadora seja habilitada a realizar o transporte.

Uma análise das possíveis soluções e seus impedimentos para estes problemas encontram-se no capítulo 8 desta dissertação. 
4.3.6 Indisponibilidade de recursos para lidar com todos os problemas

Para a solução dos problemas, é imprescindível a aplicação de recursos financeiros e humanos. Porém, a CNEN, principal órgão que regula não só o transporte de materiais radioativos, mas também a proteção radiológica e outros aspectos, encontra-se com falta de pessoal e de recursos. Isto influi, por exemplo, na atualização de normas, na agilidade de processos burocráticos como licenciamentos e capacidade de respostas a emergências. A solução para alguns problemas (alguns deles apresentados neste trabalho) já pode ter sido elaborada ou estar prevista, mas não consegue ser implementada de forma ágil por falta de recursos.

Os dados da Tabela 10 foram retirados do Portal da Transparência, do Ministério da Transparência e Controladoria Geral da União, e demonstram a atual situação da CNEN [59].

Tabela 10 - Gastos e funcionários da CNEN em 3 anos

\begin{tabular}{|c|c|c|c|c|}
\hline \multicolumn{2}{|c|}{ Informação } & 2016 & 2017 & $\begin{array}{l}2018 \text { (até } 2 \text { de } \\
\text { outubro daquele } \\
\text { ano) }\end{array}$ \\
\hline \multicolumn{2}{|c|}{$\begin{array}{c}\text { Gastos da CNEN } \\
\text { (Despesa executada) }\end{array}$} & $\begin{array}{c}903,97 \\
\text { milhões de } \\
\text { reais } \\
0,04 \% \text { dos }\end{array}$ & $\begin{array}{c}931,37 \\
\text { milhões de } \\
\text { reais } \\
0,04 \% \text { dos }\end{array}$ & $\begin{array}{c}\text { 644,28 milhões } \\
\text { de reais } \\
0,03 \% \text { dos gastos } \\
\text { públicos }\end{array}$ \\
\hline \multirow{3}{*}{$\begin{array}{c}\text { Funcionários } \\
\text { ativos }\end{array}$} & Total & 2.123 & 2.123 & 2.123 \\
\hline & Em exercício & 2.109 & 2.109 & 2.109 \\
\hline & $\begin{array}{l}\text { Afastados } \\
\text { (cedidos, em } \\
\text { licença etc.) }\end{array}$ & 14 & 14 & 14 \\
\hline
\end{tabular}

Fonte: Portal da Transparência - Comissão Nacional de Energia Nuclear. Disponível em < http://www.portaldatransparencia.gov.br/orgaos/20301-comissao-nacional-de-energia-nuclear>. Acessado em 02/10/2018.

Por meio dos dados apresentados na Tabela 10, podemos acompanhar os gastos da instituição e a quantidade de funcionários ativos de acordo com o ano. $\mathrm{O}$ primeiro comparativo possível é o gasto do órgão (que obedece aos recursos 
repassados) com a inflação do ano anterior. Teoricamente, para manter os recursos financeiros aplicados, o valor gasto pelo órgão deveria acompanhar a inflação geral do ano anterior, que é a base de previsão para o repasse de recursos. Se o gasto está acima da inflação, há o indicativo de maior repasse de recursos, ou seja, investimento. Se abaixo da inflação, há o indicativo de menor repasse de recursos, ou retirada de investimentos.

A Tabela 11 demonstra essa comparação de acordo com o Índice de Preço ao Consumidor Amplo (IPCA) e Índice Geral de Preços - Disponibilidade Interna (IPGDI) [60]. Assim temos:

Tabela 11 - Gasto da CNEN em comparação a inflação

$$
\begin{aligned}
& \begin{array}{c}
\text { Aumento de gasto em comparação } \\
\text { ao ano anterior }
\end{array} \quad \text { Inflação geral } \\
& \hline
\end{aligned}
$$

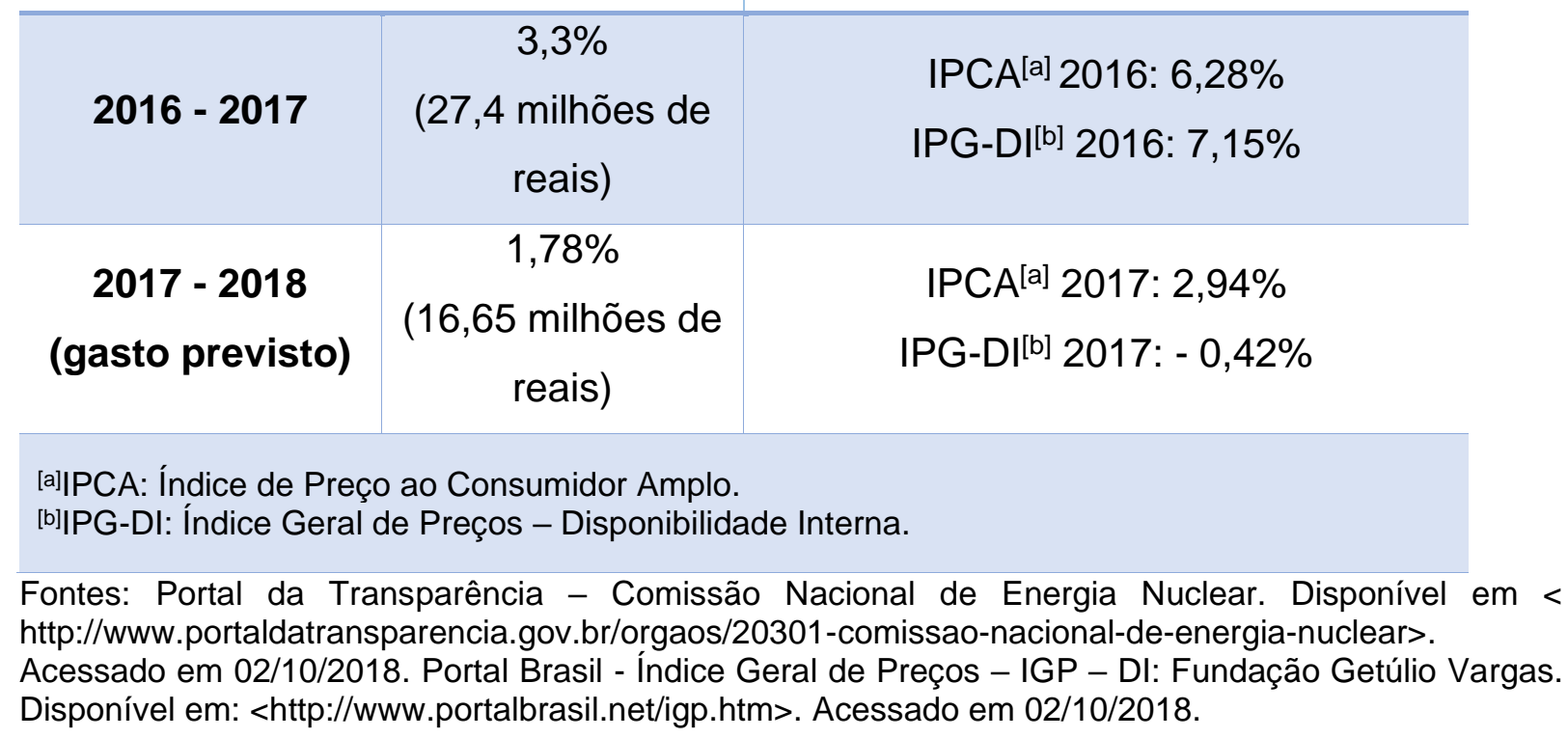

Isto demonstra que, apesar do crescimento populacional que, consequentemente aumenta a demanda de produtos e serviços ligados ao uso de radiação e sua necessidade de transporte, a CNEN não recebeu aumento de investimento. $\mathrm{O}$ trabalho administrativo e técnico da instituição cresce, enquanto seus recursos humanos e financeiros permanecem estagnados, gerando sobrecarga de trabalho para os funcionários e insuficiência de recursos para lidar com as demandas diversas que a instituição recebe. Assim, as resoluções, mesmo que sejam conhecidas, sofrem, no mínimo, lentidão em sua execução, já que o órgão responsável se encontra com diminuição de recursos para lidar com as situações. 
Em 2016, o governo federal suspendeu novos concursos por causa da crise financeira que se estabeleceu no país. A previsão de retomada dos concursos e contratações está para 2019, mas ainda enfrenta dificuldades, já que leis orçamentárias restringem os gastos por causa dos rombos bilionários em órgãos e empresas estatais. Ainda assim, as contrações se fazem necessárias, já que boa parte dos funcionários públicos federais, o que inclui as agências como a CNEN, ANTT, ANTAQ e IBAMA, tem previsão de aposentadoria dentro de um curto espaço de tempo [61]. 


\section{PREJUÍZOS ESTIMADOS}

A Tabela 12 foi fornecida pelo Comitê Nacional e compila as consequências das recusas e demoras no transporte de materiais radioativos. As informações competem, também, ao ocorrido em âmbito internacional. O Comitê Nacional considerou as ocorrências internacionais, nacionais e cedidas por empresas brasileiras. A tabela também fornece a especificação do produto transportado, o modal de transporte e a gravidade (severidade) da consequência.

Tabela 12 - Tabela de consequências de recusas e demoras no transporte de material radioativo (continua)

\begin{tabular}{|c|c|c|c|}
\hline $\begin{array}{l}\text { Produto classe } \\
7 \text { (Radioativo) }\end{array}$ & $\begin{array}{l}\text { Modal de } \\
\text { Transporte }\end{array}$ & $\begin{array}{l}\text { Consequências das Recusas ou } \\
\text { Demoras }\end{array}$ & Severidade \\
\hline $\begin{array}{l}\text { Radiofármacos } \\
\text { Radioquímicos }\end{array}$ & $\begin{array}{l}\text { Rodoviário } \\
\text { Aéreo }\end{array}$ & $\begin{array}{l}\text { Prejuízo para a saúde pública, o produto } \\
\text { perdido devido à meia-vida curta, aumento } \\
\text { dos custos dos cuidados à saúde e } \\
\text { utilização ineficaz dos recursos para a } \\
\text { saúde. } \\
\text { Legislação Brasileira fragmentada, } \\
\text { causando interferências estaduais e } \\
\text { municipais em competências federais. }\end{array}$ & Alta \\
\hline $\begin{array}{c}\text { Fontes de } \\
\text { Calibração e } \\
\text { Referência } \\
\text { (Categorias 1-5) }\end{array}$ & $\begin{array}{c}\text { Rodoviário } \\
\text { Aéreo }\end{array}$ & $\begin{array}{l}\text { Risco de segurança para as fontes } \\
\text { categoria } 1 \text { e categoria } 2 \text {, interrupção dos } \\
\text { serviços de calibração, prejuízo à saúde } \\
\text { pública. Fontes de referência para } \\
\text { calibração e medicina nuclear. }\end{array}$ & Baixa a Alta \\
\hline $\begin{array}{l}\text { Fontes para } \\
\text { teleterapia e } \\
\text { radiocirurgia } \\
\text { (Categorias 1-2) }\end{array}$ & $\begin{array}{l}\text { Rodoviário } \\
\text { Aéreo } \\
\text { Marítimo }\end{array}$ & $\begin{array}{l}\text { Risco de segurança, prejuízo para a saúde } \\
\text { pública atrasando ou restringindo o } \\
\text { tratamento do paciente, potencial redução } \\
\text { do número de pacientes atendidos. }\end{array}$ & Alta \\
\hline $\begin{array}{c}\text { Fontes para } \\
\text { irradiadores } \\
\text { (Categorias 1-3) }\end{array}$ & $\begin{array}{l}\text { Rodoviário } \\
\text { Aéreo }\end{array}$ & $\begin{array}{l}\text { Risco de segurança para as fontes } \\
\text { categoria } 1 \text { e categoria } 2 \text {, interrupção dos } \\
\text { serviços de calibração, prejuízo para a } \\
\text { saúde pública (irradiadores de sangue), } \\
\text { prejuízo para a pesquisa, utilização ineficaz } \\
\text { da pesquisa e financiamento dos cuidados } \\
\text { de saúde. }\end{array}$ & $\begin{array}{l}\text { Alta para } \\
\text { Fontes de } \\
\text { categorias } 1 \\
\quad \text { e } 2\end{array}$ \\
\hline
\end{tabular}


Tabela 12 - Tabela de consequências de recusas e demoras no transporte de material radioativo

\begin{tabular}{|c|c|c|c|}
\hline & & & (continuação) \\
\hline $\begin{array}{l}\text { Irradiadores de } \\
\text { Grande Porte } \\
\text { (Categoria 1) }\end{array}$ & $\begin{array}{l}\text { Rodoviário } \\
\text { Marítimo }\end{array}$ & $\begin{array}{l}\text { Risco de segurança, aumento do custo de } \\
\text { esterilização de produtos, escassez de } \\
\text { produtos descartáveis médicos estéreis e } \\
\text { interrupção no processamento de } \\
\text { alimentos, crescimento de volumes que } \\
\text { requerem esterilização, poderá ocorrer } \\
\text { escassez (muito pouco estoque ocorre por } \\
\text { causa dos volumes produzidos e a } \\
\text { necessidade do comprador, que solicita } \\
\text { para uso imediato ou em curto prazo). }\end{array}$ & $\begin{array}{c}\text { Moderada a } \\
\text { Alta }\end{array}$ \\
\hline $\begin{array}{l}\text { Fontes para } \\
\text { radiografia } \\
\text { (Categorias } 2 \text { e } \\
\text { 3) }\end{array}$ & $\begin{array}{l}\text { Rodoviário, } \\
\text { aéreo }\end{array}$ & $\begin{array}{l}\text { Interrupção de projetos de infraestrutura de } \\
\text { negócios e de manutenção que } \\
\text { comprometem a segurança pública. }\end{array}$ & $\begin{array}{l}\text { Baixa a } \\
\text { média }\end{array}$ \\
\hline $\begin{array}{l}\text { Combustível } \\
\text { Nuclear } \\
\left(\mathrm{U}_{3} \mathrm{O}_{8}, \mathrm{UF}_{6} \mathrm{e}\right. \\
\text { elementos } \\
\text { combustíveis) }\end{array}$ & $\begin{array}{l}\text { Rodoviário } \\
\text { Marítimo }\end{array}$ & $\begin{array}{l}\text { Segurança do fornecimento de combustível } \\
\text { às instalações nucleares afetadas: risco ao } \\
\text { sistema de proteção física como material } \\
\text { enviado indiretamente, mais países } \\
\text { decidem desenvolver instalações de ciclo } \\
\text { de combustível sensíveis à proliferação. } \\
\text { Segurança do fornecimento de combustível } \\
\text { às instalações nucleares afetadas: elevação } \\
\text { do risco associado ao sistema de proteção } \\
\text { física, aumento do custo operacional no } \\
\text { Terminal Portuário. }\end{array}$ & Baixa \\
\hline
\end{tabular}

\begin{tabular}{|l|c|l|c|}
\hline Amostras de UF6 & Aéreo & $\begin{array}{l}\text { Dificuldades para AlEA em conduzir em } \\
\text { tempo as análises na área das } \\
\text { Salvaguardas. }\end{array}$ & Baixa \\
\hline $\begin{array}{l}\text { Fontes em } \\
\text { desuso }\end{array}$ & $\begin{array}{c}\text { Aéreo } \\
\text { Marítimo }\end{array}$ & $\begin{array}{l}\text { Dificuldade em despachar fontes oriundas } \\
\text { de países onde o sistema de gestão é } \\
\text { deficiente devido à falta de infraestrutura, } \\
\text { falta de expertise ou devido à agitação } \\
\text { política. }\end{array}$ & $\begin{array}{c}\text { Baixa a } \\
\text { Média }\end{array}$ \\
\hline $\begin{array}{l}\text { Minério de } \\
\text { tântalo }\end{array}$ & Marítimo & $\begin{array}{l}\text { Segurança do suprimento. Efeitos adversos } \\
\text { nas economias africanas que exportam } \\
\text { metade do minério do mundo. }\end{array}$ & $\begin{array}{c}\text { Não } \\
\text { mencionado }\end{array}$ \\
\hline $\begin{array}{l}\text { Minério contendo } \\
\text { material } \\
\text { radioativo de } \\
\text { ocorrência }\end{array}$ & $\begin{array}{c}\text { Não } \\
\text { mencionado }\end{array}$ & $\begin{array}{l}\text { Segurança do suprimento. Efeitos adversos } \\
\text { nas economias africanas que exportam } \\
\text { metade do minério do mundo, e na } \\
\text { economia Brasileira. }\end{array}$ & $\begin{array}{c}\text { Não } \\
\text { mencionado }\end{array}$ \\
\hline
\end{tabular}


Tabela 12 - Tabela de consequências de recusas e demoras no transporte de material radioativo

\begin{tabular}{|c|c|c|c|}
\hline & & & (continuação) \\
\hline $\begin{array}{l}\text { Produtos, } \\
\text { Subprodutos e } \\
\text { Amostras de } \\
\text { origem NORM }\end{array}$ & $\begin{array}{l}\text { Rodoviário } \\
\text { Aéreo } \\
\text { Marítimo }\end{array}$ & $\begin{array}{l}\text { Dificuldades em desembaraçar e sanar } \\
\text { dúvidas recorrentes de agentes } \\
\text { fiscalizadores e de empresas de transporte } \\
\text { aéreo e marítimo no transporte de material } \\
\text { NORM, ocasionando instabilidade nos } \\
\text { negócios, desenvolvimento socioeconômico } \\
\text { e pesquisa e desenvolvimento. }\end{array}$ & Média a Alta \\
\hline
\end{tabular}

Fonte: Comitê Nacional de Recusas e Demoras no Transporte de Materiais Radioativos, 2017.

A seguir serão discutidas as consequências que levam a prejuízos financeiros e a outros prejuízos.

\subsection{Prejuízos financeiros}

A recusa e demora no transporte pode causar, como já descrito, a perda do material transportado, especialmente para radioisótopos de meia via curta, e incremento no custo do transporte. Nesta situação, deve se considerar que o material decai constantemente. Logo, mesmo que a demora não ultrapasse o tempo de uma meia-vida física, o produto chegará ao destino com uma atividade menor do que a esperada e pode ficar inutilizado dependendo das condições ideais de uso.

O Instituto de Pesquisas Energéticas e Nucleares (IPEN) possui uma divisão de radiofarmácia que fabrica produtos diversos para uso no diagnóstico e terapia. Supondo-se que ocorram situações como as descritas ao longo deste trabalho, nas quais o material radioativo decai e fica inutilizável, além do comprometimento das características biológicas do medicamento, o primeiro prejuízo que se pode estimar é o do valor da mercadoria. A Tabela 13 apresenta, resumidamente, o valor de alguns destes materiais, sua meia-vida e para que seriam utilizados. Os valores foram cedidos pelo IPEN em 2018. O tempo de meia-vida e a utilização foram retirados da bula farmacêutica do produto, fornecida pelo IPEN. 
Tabela 13 - Radiofármacos transportados: utilização e valor comercial

\begin{tabular}{|c|c|c|c|}
\hline Produto & $\begin{array}{l}\text { Tempo de } \\
\text { meia-vida }\end{array}$ & Utilização & Valor / custo \\
\hline $\begin{array}{l}\text { Gerador de } \\
\text { Tecnécio- } \\
99 \mathrm{~m}\end{array}$ & $\begin{array}{c}66 \text { horas - } \\
\text { Molibidênio- } \\
99 \mathrm{~m} \text { que } \\
\text { gera o } \\
\text { Tecnécio- } \\
99 \mathrm{~m}-6 \\
\text { horas }\end{array}$ & 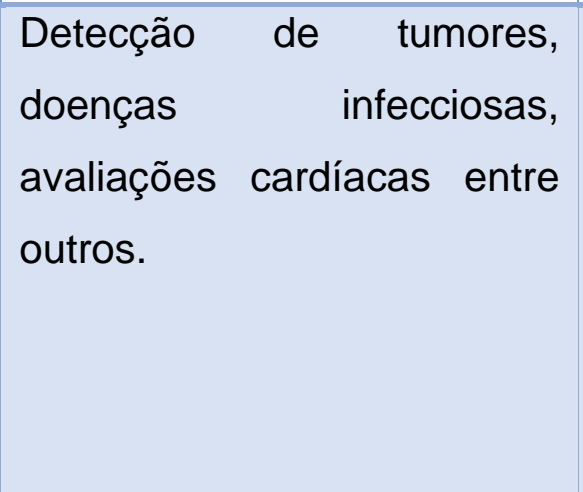 & $\begin{array}{l}\mathrm{De} \approx \mathrm{R} \$ 2.000 \mathrm{a} \\
\mathrm{R} \$ \quad 6.800 \quad \mathrm{a} \\
\text { depender da } \\
\text { atividade. }\end{array}$ \\
\hline Gálio-67 & 78,3 horas & $\begin{array}{l}\text { Detecção de tumores e } \\
\text { detecção de inflamações e } \\
\text { infecções de origem } \\
\text { desconhecida. }\end{array}$ & $\begin{array}{l}\mathrm{De} \approx \mathrm{R} \$ 240,00 \\
\text { a } \mathrm{R} \$ 1.200,00 \mathrm{a} \\
\text { depender da } \\
\text { atividade. }\end{array}$ \\
\hline Tálio-201 & 73,1 horas & $\begin{array}{l}\text { Avaliação da perfusão } \\
\text { miocárdica, imagem das } \\
\text { paratireoides e imagens } \\
\text { tumorais. }\end{array}$ & $\begin{array}{l}\mathrm{De} \approx \mathrm{R} \$ 440,00 \\
\text { a } \mathrm{R} \$ 4.500,00 \mathrm{a} \\
\text { depender da } \\
\text { atividade. }\end{array}$ \\
\hline $\begin{array}{l}\text { EDTMP- } \\
\text { Samário- } \\
153\end{array}$ & 46,7 horas & $\begin{array}{l}\text { Terapia paliativa da dor } \\
\text { provocada por metástases } \\
\text { ósseas. }\end{array}$ & $\begin{array}{l}\approx \mathrm{R} \$ 540,00 \\
\text { cada dose. }\end{array}$ \\
\hline $\begin{array}{l}\text { Octreotato } \\
\text { tetraxetana } \\
\text { (Gálio-68) }\end{array}$ & 68 minutos & $\begin{array}{l}\text { Diagnóstico de tumores } \\
\text { neuroendócrinos. }\end{array}$ & $\begin{array}{l}\approx \mathrm{R} \$ 2600,00 \\
\text { cada dose. }\end{array}$ \\
\hline Lutécio-177 & 6,7 dias & $\begin{array}{l}\text { Terapia de tumores } \\
\text { neuroendócrinos. }\end{array}$ & $\begin{array}{l}\approx \mathrm{R} \$ 2700,00 \\
\text { cada dose. }\end{array}$ \\
\hline $\begin{array}{l}\text { lodo-131 em } \\
\text { cápsulas }\end{array}$ & 8 dias & $\begin{array}{l}\text { Tratamento de doenças } \\
\text { benignas e malignas da } \\
\text { tireoide. }\end{array}$ & $\begin{array}{l}\mathrm{De} \approx \mathrm{R} \$ 240,00 \\
\text { a } \mathrm{R} \$ 1200,00 \mathrm{a} \\
\text { depender da } \\
\text { atividade. }\end{array}$ \\
\hline
\end{tabular}

Fonte: Instituto de Pesquisas Energéticas e Nucleares. 
Outro fato a se considerar é que dificilmente uma operação de transporte carrega somente uma unidade dos produtos descritos na tabela acima. A quantidade a ser transportada é regulada pelo número de IT, como descrito no capítulo 2 . O trabalho de Demerval Leônidas Rodrigues contém dados sobre o carregamento de algumas unidades de transporte terrestre, já que tratou da dosimetria durante este tipo de operação no IPEN. O número médio de embalados por veículo é 29. Que, no caso avaliado, transportavam principalmente geradores de Tecnécio-99m e lodo-131 [62]. Considerando uma operação regular como esta, o valor aproximado transportado seria de:

Embalados por veículo $x$ custo médio dos embalados $29 \times$ ([valor médio gerador de Tecnécio-99m + valor médio lodo-131] /2)

$$
29 \times([720,00+720,00] / 2)=R \$ 20.880,00
$$

Este valor representa a carga de um único veículo terrestre, transportando Tecnécio-99m e lodo-131. No transporte aéreo o volume transportado é significativamente maior, já que a operação de transporte (uma aeronave) muitas vezes atende a mais de uma transportadora terrestre por vez. Se uma aeronave, por exemplo, transportar o conteúdo de quatro veículos terrestres contendo a carga mencionada, o valor transportado é de aproximadamente $\mathrm{R} \$ 83.520,00$.

Se considerarmos outros materiais radioativos, como o Gálio-68, Gálio-67, Tálio-201 ou Lutécio-177, o valor transportado se eleva e, juntamente com ele, o prejuízo financeiro em caso de recusa ou demora.

Já o transporte marítimo lida com materiais radioativos de meia-vida mais longa, como minérios radioativos e fontes industriais, não havendo grandes problemas por causa da demora do transporte em relação ao decaimento radioativo e perda de atividade. Porém, os valores dos materiais transportados, inclusive por causa de seu maior volume, são maiores se comparados com o transporte de radiofármacos. A recusa, nestes casos, é mais grave. O grande problema é que o possuidor da fonte não a dispõe para realizar a sua atividade e com isso perde por falta de contratações de serviço. A escassez de transportadoras no modal marítimo foi descrita no subcapítulo 4.2.4.2. Os prejuízos de perda de clientes e inviabilidade de negócios por causa da 
indisponibilidade do transporte marítimo varia de $\$ 100$ mil a alguns milhões de dólares a depender da carga e da operação, segundo os entrevistados.

O gráfico a seguir demonstra uma estimativa dos prejuízos financeiros que as instituições entrevistadas durante este trabalho alegaram já ter sofrido por causa das recusas e demoras no transporte. Os respondentes são transportadores e expedidores de material radioativo. Como o valor monetário depende do material transportado, meio de transporte e outros fatores, procurou-se estimar a magnitude através do ganho que as empresas teriam. Neste caso, saber se o prejuízo financeiro causado pelas recusas e demoras é inferior, equivalente ou superior ao ganho que se teria caso o problema não houvesse ocorrido.

\section{Gráfico 7 - Estimativa de prejuízo financeiro sofrido pelas empresas}

\section{Magnitude do prejuízo financeiro sofrido com a recusa e/ou demora \\ Total de respondentes: 18}

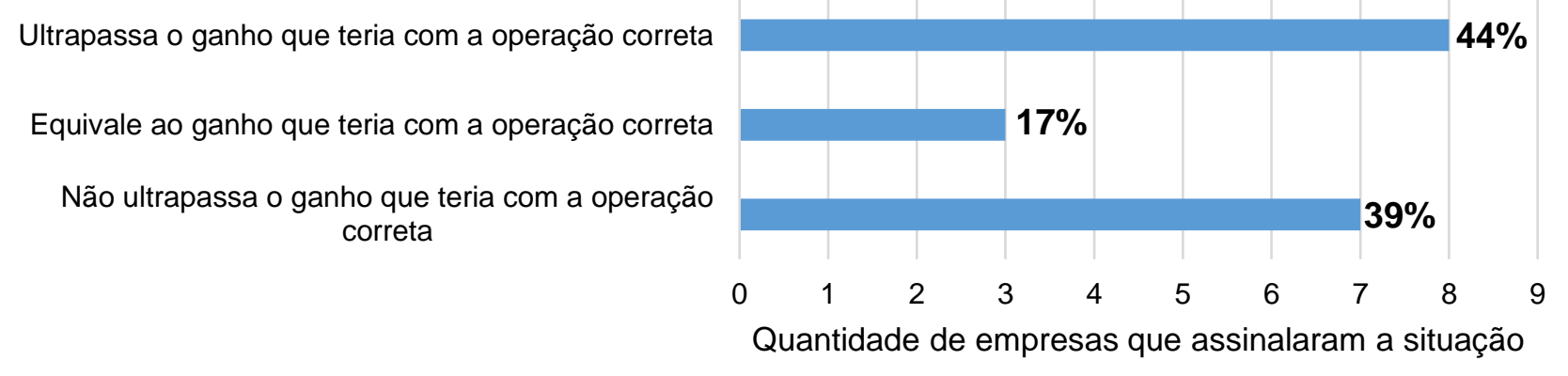

Fonte: autor da dissertação.

\subsection{Outros prejuízos}

Além do prejuízo financeiro em si, outros prejuízos como a perda de clientes, problemas com funcionários, redução da demanda de serviço e prejuízo da imagem social da empresa foram descritos durante os encontros [7, 25, 51].

O gráfico 8 mostra os prejuízos não financeiros que as instituições entrevistadas por este trabalho alegaram já ter sofrido por causa das recusas e demoras no transporte. Os respondentes são transportadores e expedidores de material radioativo. 
Logicamente, estes prejuízos podem desencadear o prejuízo financeiro, especialmente quando se verifica que o mais frequente entre eles é a perda de clientes (57\% dos entrevistados).

Outro prejuízo a ser considerado, é aquele sofrido pelos usuários do material radioativo. O maior exemplo encontra-se na medicina com uso de radiofármacos. Pacientes de todo país dependem do transporte do material radioativo para realizar diagnósticos de enfermidades como cânceres e suas metástases, insuficiência renal, insuficiência cardíaca, entre muitas outras, por meio da cintilografia, exame da medicina nuclear, além de tratamentos como o do câncer de tireoide e do hipertireoidismo.

\section{Gráfico 8 - Prejuízos não financeiros sofridos pelas empresas}

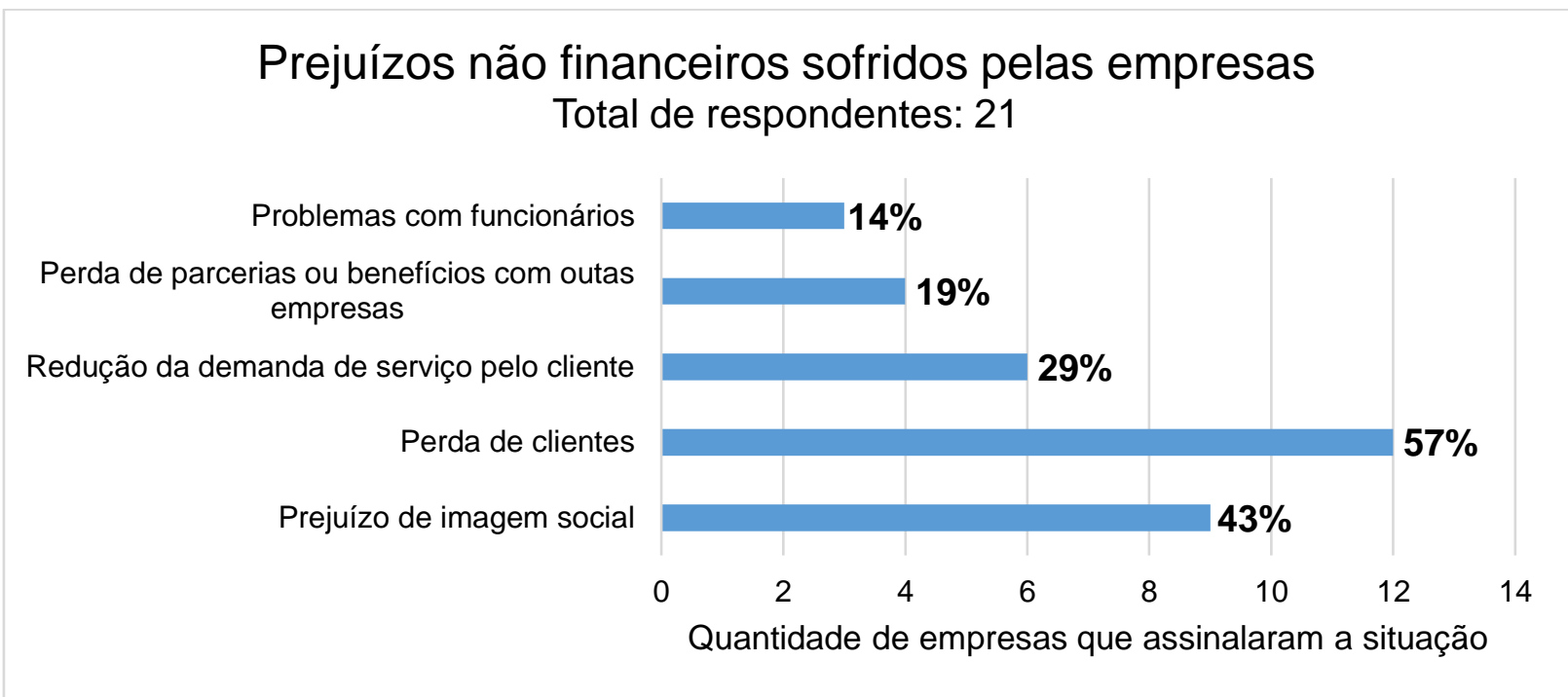

Fonte: autor da dissertação.

Durante as entrevistas, relatou-se que muitos desses pacientes aguardam meses para realização do procedimento, especialmente os atendidos pelo Sistema Único de Saúde (SUS). Se o material radioativo não chega no prazo esperado, o paciente tem de ser remarcado. Em centros médicos distantes dos expedidores existentes, o paciente, por vezes, aguarda o material com o acesso venoso pronto, e só depende da entrega para realização do exame ou do tratamento. Quando recusados ou demorados, há grande possibilidade de perder-se os radiofármacos em transporte por causa de sua meia-vida curta e decaimento radioativo rápido. Assim, os pacientes não conseguem realizar o procedimento na data agendada. Tem-se que considerar que certas patologias podem progredir rapidamente enquanto 0 paciente aguarda 0 
diagnóstico ou tratamento e que, dependendo do centro médico e do tipo de material radioativo, sua espera pode ser prolongada por mais alguns meses, agravando 0 quadro clínico. 


\section{ESFORÇOS PARA SOLUCIONAR OS PROBLEMAS MENCIONADOS NO CAPÍTULO 4: AÇÕES DO COMITÊ NACIONAL DE RECUSAS DE DEMORAS}

O início da resolução das recusas e demoras pelo Comitê Diretivo Internacional de 2003, ou da busca por esta, deu-se pela formação de grupos de trabalho para elaboração de um plano de ação. $O$ documento consiste de um conjunto de medidas e tarefas a serem realizadas por um grupo de interessados que pode envolver empresas, órgãos governamentais e outros vinculados ao transporte de material radioativo. As ações a serem tomadas variam de acordo com o modal. Porém, a ideia do plano de ação foi aceita e executada por diversos países participantes dos Comitês [1].

Assim, foi criado o plano de ação nacional, baseado no plano de ação internacional apresentado pelo OIEA, mas não restrito a ele [7]. O plano nacional teve, incialmente, seis campos de ação, que seguem descritos:

Alerta, sensibilização e mobilização: Esta medida visa realizar o levantamento das recusas e demoras ocorridos, os prejuízos econômicos, sociais e de imagem causados, e a comunicação com as partes interessadas para que haja mobilização. Sua execução inclui o contato com diferentes empresas envolvidas no processo de transporte de materiais radioativos, a fim de que participem do comitê; além da identificação de empresas com potencial para realizar o transporte de material radioativo, aumentando a possibilidade do transporte.

Educação, treinamento e competência: fornecer o conhecimento necessário a todos os envolvidos no processo de transporte de materiais radioativos de forma que consigam cumprir com as exigências regulamentares. As ações incluem a organização de cursos, tradução de documentos específicos, viabilização de encontros e grupos trabalho e busca de recursos financeiros para sua execução.

Comunicação: propagar a informação sobre o problema e incentivar a participação de possíveis interessados. As ações incluem o contato com empresas em potencial e criação de canais de comunicação e divulgação de informações. 
Promoção do uso da energia nuclear: desmistificar o uso da energia nuclear e promover uma imagem positiva do seu uso para a sociedade. Realizada por todos os membros do comitê quando houver a oportunidade em palestras, seminários, workshops etc.

Impacto econômico: relato e quantificação dos prejuízos financeiros por causa das recusas e demoras no transporte de materiais radioativos. Estimar os prejuízos sociais e de imagens. Realizar também sua divulgação para os envolvidos e procurar soluções para minimizá-los.

Harmonização da legislação e da regulamentação: identificar inconsistências entre as legislações e regulamentações vigentes nos país. Acionar os órgãos envolvidos e estudar as formas de harmonização. Atentar, também, à informações cedidas em revistas, periódicos e outros meios de comunicação, verificando sua compatibilidade com a legislação e regulamentação vigentes, evitando a propagação de informações errôneas.

\subsection{Esforços para redução dos problemas com a legislação}

Como disposto no capítulo 4 deste trabalho, as incompatibilidades entre as normas vigentes no país causam diversos problemas no transporte de materiais radioativos. As reuniões do Comitê possibilitaram o contato entre os profissionais de diferentes órgãos reguladores e transportadores, que puderam unir esforços para harmonizar a legislação e torná-la praticável.

No caso exposto pelo item 4.3.2 deste trabalho, membros da CNEN e do IBAMA uniram esforços para formular um termo de referência conjunto, expedido em 2013 [32]. Originalmente, o formulador do termo de referência para licenciamento ambiental é o IBAMA, já que foi idealizado para obter o licenciamento ambiental, necessário, inclusive, para as operações de transporte, [63]. Porém, o termo expedido em 2013 foi realizado de forma conjunta entre CNEN e IBAMA, de forma que as exigências correspondessem ao cumprimento dos requisitos de ambos os órgãos. Nele estão contidos:

a) As atribuições que competem ao IBAMA e a CNEN e as leis que regulamentam suas atuações; 
b) Como são classificados os materiais radioativos e seus embalados para transporte;

c) As normas que sustentam as informações ali contidas e devem ser consultadas pelo transportador;

d) Uma tabela que sumariza os documentos necessários em cada caso de transporte;

e) Um modelo para elaboração do Plano de Transporte, que está de acordo com o que é aceito por ambos os órgãos para obter as autorizações necessárias.

Este tipo de documento visa facilitar o entendimento da legislação e auxilia grandemente os envolvidos no transporte a não cometerem erros por causa de má interpretação. De acordo com as reuniões do Comitê, há a intenção de fazer com que outros órgãos como a ANTAQ, ANTT e secretarias municipais e estaduais de proteção ao meio ambiente adiram ao termo de referência conjunto. Assim, o transportador teria acesso a um conjunto de exigências que atenderiam, simultaneamente, a todas as legislações vigentes.

Outro exemplo de harmonização entre as normas vigentes aconteceu na atualização norma ANTT no 5.232 [34], como descrito no subcapítulo 4.3.2. Em seu escopo, a norma não possui descrição das exigências para o transporte de material radioativo. Ao invés disso, solicita que sejam cumpridos os requisitos da CNEN, em suas respectivas normas. Logo, se cumpridas as exigências das normas da CNEN, a ANTT considera o transporte da classe 7 como correto e de acordo com sua própria normatização. Esta harmonização foi possível graças ao trabalho do Comitê Nacional, do qual a CNEN e a ANTT fazem parte e decidiram ser este o caminho mais simples para desburocratização do processo de regulamentação do transporte de material radioativo. Assim, o transportador não precisa consultar duas normas para adequar-se, o que facilita a interpretação do texto e reduz a possibilidade de problemas com más interpretações, além de reduzir potencialmente inconsistências entre as exigências das duas instituições, já que estas serão as mesmas para ambas.

O Comitê Nacional realiza um trabalho contínuo de identificação de normas e leis nacionais e internacionais que possam causar recusas ou demoras no transporte de material radioativo. Quando identificadas, geralmente são discutidas nos encontros 
e um grupo de trabalho é formado para tentar solucionar o problema. É o que aconteceu, por exemplo, com os casos das leis do município de São Paulo e do estado de Minas Gerais, que ainda não foram encerrados, mas há um grupo de trabalho tentando contato com os respectivos responsáveis.

\subsection{Outros esforços}

Para agilizar o transporte de radiofármacos no modal aéreo, conseguiu-se, através dos esforços do Comitê Nacional, a prioridade no embarque e isenção de autorização para transporte. Esta prioridade consta na norma RBAC 175 da ANAC [17] e faz com que o tempo de transporte seja reduzido, minimizando assim as chances de atraso e eventual perda de atividade do material radioativo. Outras ações, como a participação na revisão da norma e sugestões de alteração vem sendo tomadas. Em 2018, o Comitê Nacional efetivou sua participação durante a revisão de alteração da RBAC 175. As principais sugestões de alteração foram:

a) Aumentar o número de IT permitido para um único embalado quando transportado em aeronave de passageiros. Atualmente, permite-se um IT igual ou inferior a 3 para um embalado individual e 50 ou menos para o conjunto de embalados transportados. Este requisito limita a quantidade de material radioativo em um único embalado. No caso dos radiofármacos, uma atividade que resulta em um IT maior que 3 tem de ser distribuída em mais de um embalado para conseguir ser transportada, aumentando o volume de embalados e ocupando maior espaço no porão da aeronave, o que também limita a capacidade de transporte da aeronave;

b) Isentar supervisores de proteção radiológica certificados pela CNEN da obrigatoriedade do curso exigido pela ANAC para o transporte de produtos perigosos, já que estes profissionais possuem conhecimento superior aos apresentados no curso;

c) Não permitir que o material radioativo exceptivo, números ONU 2910 e 2911, seja incluído no transporte por mala postal, já que contradiz a norma da CNEN 5.01 e a lei federal número 6.538 de 22 de junho de $1978[4,64]$.

Além disso, no campo da comunicação e captação de partes interessadas, o Comitê Nacional tem reunido de forma efetiva representantes de expedidores, 
produtores de embalagens, transportadores terrestres, aéreos e marítimos. Por vezes, membros do poder legislativo e executivo da federação, do estado ou dos municípios, autoridades fiscais diversas, entre outros, são contatados por um grupo de trabalho ou por um membro do Comitê Nacional, que realizam o trabalho de informação e sensibilização sobre o transporte de material radioativo. 


\section{O MEDO DA RADIAÇÃO E O PROBLEMA DOS TRASNPORTES}

O medo da radiação ionizante é apontado como um dos principais fatores que causam recusas e demoras. Este medo leva os envolvidos no transporte a recusar o material, ou, em alguns casos, se confundirem sobre a necessidade de procedimentos de segurança.

Um transportador relatou que certa vez um dos veículos transportando material radioativo foi parado na cidade de São Paulo para fiscalização. Ao saber que se tratava de material radioativo, o agente fiscal não quis conferir a documentação ou qualquer aspecto de segurança do transporte, solicitando ao motorista que seguisse em frente o mais rápido possível. Isto com certeza não gera recusa ou demora, mas explicita a percepção exacerbada que o público possui do malefício causado pela radiação ionizante.

Durante a pesquisa com o Grupo 2, por diversas vezes, os participantes expressaram sua percepção de que o transporte de material radioativo seria o mais perigoso dentre todas as oito classes de produtos perigosos. O motivo alegado para esta afirmação é que o material radioativo não é perceptível aos sentidos, diferente dos demais produtos. Assim, os trabalhadores e pessoas envolvidas em um acidente não teriam como perceber o perigo. Também há a percepção de que, se um material radioativo fosse exposto durante um acidente, as consequências para os trabalhadores e para a população seriam muito mais graves do que o vazamento de outros materiais, como gases explosivos e químicos, por exemplo. Um dos participantes, motorista de cargas perigosas há 12 anos, declarou que "evitaria ao máximo trabalhar com este tipo de transporte, e só o faria se não houvesse outra opção".

Outros trabalhos desenvolvidos no país demonstram este medo em estudantes do ensino superior, estando menos presentes em cursos das áreas exatas e mais presentes em cursos da área biológica e de humanas [65]. Também no ensino médio, percebeu-se que o maior medo ligado à radiação ionizante é o risco de desenvolver câncer, mas que discussões em salas de aula e a busca por informações 
seguras sobre o tema melhoram e favorecem o uso da tecnologia nuclear em diversas aplicações [66].

Como descrito no capítulo 2, este trabalho aplicou um questionário para mensurar o medo da radiação ligado ao transporte de material radioativo em dois grupos. A comparação entre as duas percepções é dada a seguir.

\section{Gráfico 9 - Comparação de histogramas: fator 1}

Grupo 1 - Fator 1: medo relacionado a acidentes e problemas de saúde

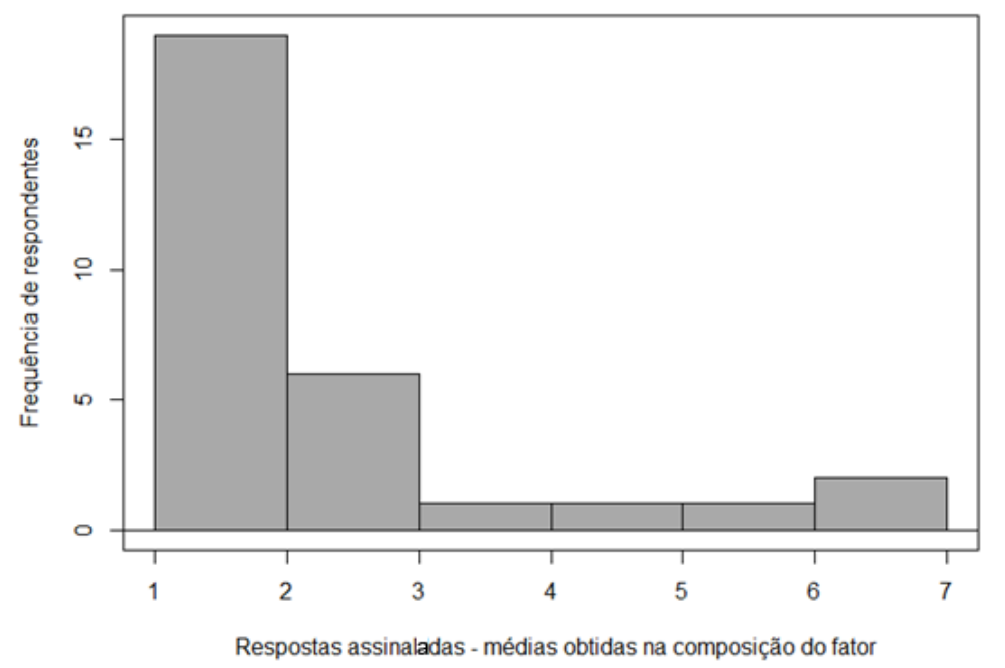

Grupo 2 - Fator 1: medo relacionado a acidentes e problemas de saúde

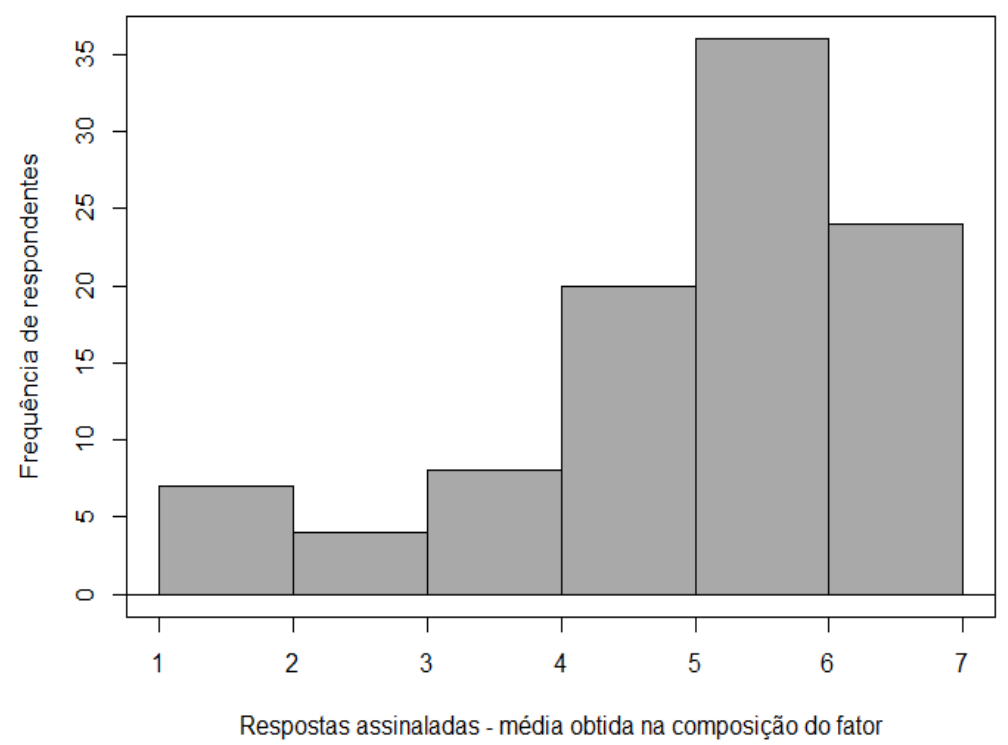

Fonte: Autor da dissertação. 
Considerando os intervalos do histograma, podemos dividir o fator de medo de acidentes e problemas de saúde durante o transporte como:

Intervalo de 1 a 3: medo ausente ou fraco

Intervalo de 3 a 5: indecisão sobre o assunto, ponto médio da concordância Intervalo de 5 a 7 : medo presente a forte

Visualmente, percebe-se a maior concentração de respostas no intervalo de 1 a 3 para o Grupo 1 e no intervalo de 5 a 7 para o Grupo 2, mostrando notável discrepância na percepção de periculosidade e confirmando a presença do medo da radiação ionizante durante o transporte em indivíduos que não trabalham diretamente com este tipo de material.

Numericamente, 10\% do Grupo 1 e 60\% do Grupo 2 apresentaram médias que indicam a presença do medo no fator 1. No Grupo 1,83\% dos participantes apresentou uma média que indica ausência do medo ou medo fraco, enquanto no Grupo 2 a média foi atingida por aproximadamente 11\% dos participantes. O intervalo de indecisão foi atingido por aproximadamente 7\% do Grupo 1 e aproximadamente 29\% do Grupo 2.

A Tabela 14 compara a distribuição de média geral e de quartis para ambos os grupos no fator 1 . O valor $p$ para esta análise em ambos os grupos foi menor que 0.01 .

Tabela 14 - Distribuição numérica dos Grupos 1 e 2 para o fator 1

\begin{tabular}{|c|c|c|}
\hline Fator de análise & Grupo 1 & Grupo 2 \\
\hline $\begin{array}{c}\text { Média geral } \\
\text { da quartil, 25\% frequência }\end{array}$ & 2,26 & 5,10 \\
\hline $2^{\circ}$ quartil, 50\% & 1,16 & 4,41 \\
da frequência & 1,58 & 5,33 \\
\hline $3^{\circ}$ quartil, 75\% & & \\
da frequência & 2,75 & 6,00 \\
\hline
\end{tabular}

Fonte: autor da dissertação. 
A distribuição dos quartis permite avaliar a quantidade de indivíduos que se encontram em um certo intervalo de resposta. Como a média considera a todos, respostas extremas podem alterá-la para mais ou para menos. Assim, mesmo que uma maioria de indivíduos tenha alcançado, por exemplo, médias pequenas, uma minoria de indivíduos com respostas e médias grandes tornam a média geral maior que a da maioria, criando especulações falsas [14].

Verificando os quartis, percebe-se que $75 \%$ dos participantes do Grupo 1 atingiram uma média de até 2,75 no fator 1 , confirmando o histograma e indicando que a maioria se encontra no intervalo de ausência ou pouco medo da radiação ionizante durante o transporte. A média geral também reforça esta conclusão, atingindo o valor de 2,26. No Grupo 2, 75\% dos participantes resultam em uma média máxima igual a 6,00 , enquanto $50 \%$ atingiram uma média máxima de 5,33, e $25 \%$ uma média de até 4,33. Isto significa que pouco menos da metade dos participantes do Grupo 2 se encontra no intervalo de indecisão ou abaixo dele, enquanto a outra metade está, com certeza, acima dele, no intervalo de presença de medo. A distribuição então, confirma o histograma e as porcentagens encontradas anteriormente.

Assim, fica evidente a diferença na percepção de medo de acidentes e problemas de saúde no transporte de materiais radioativos entre pessoas envolvidas diretamente com 0 transporte da classe 7 e transportadores de outros produtos perigosos, evidenciando que o treinamento recebido pelo Grupo 2 não foi suficiente para eliminar o medo, que é relacionado a recusas e demoras.

O fator 2, comparado por histogramas no gráfico 9 , representa o medo que os participantes possuem de a empresa sofrer prejuízos de imagem social ao transportar a classe 7. Utilizando os mesmos intervalos do fator 1, temos que aproximadamente $57 \%$ do Grupo 1 e $43 \%$ do Grupo 2 estão no intervalo de ausência do medo ou possuem pouco medo. A presença do medo ou medo forte corresponde a $10 \%$ do Grupo 1 e $21 \%$ do Grupo 2. O intervalo de indecisão atinge aproximadamente $37 \%$ do Grupo 1 e $36 \%$ do Grupo 2. 


\section{Gráfico 10 - Comparação de histogramas: fator 2}

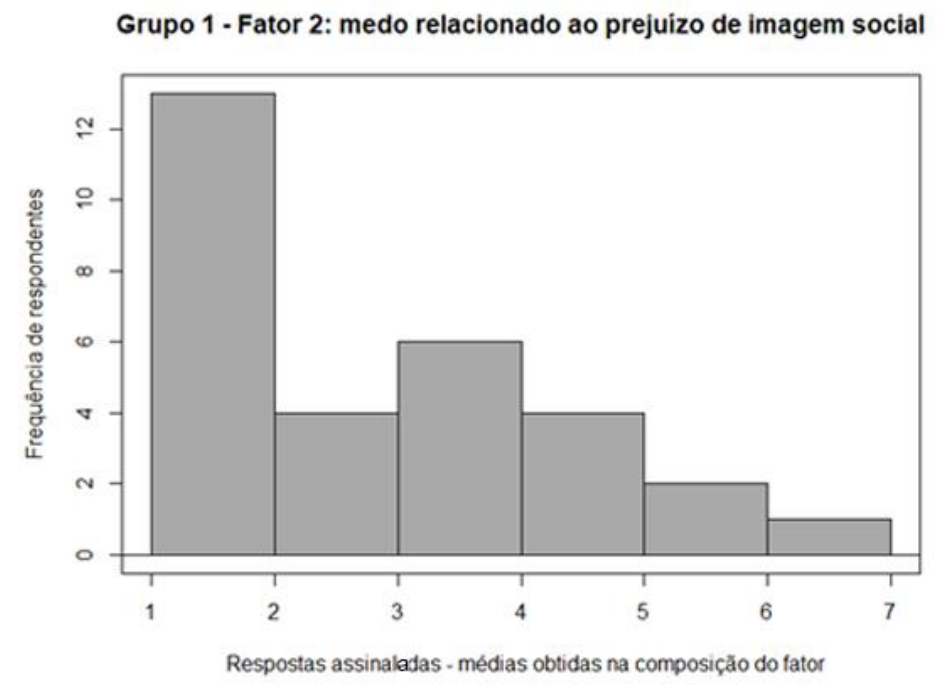

Grupo 2 - Fator 2: medo relacionado ao prejuízo de imagem social

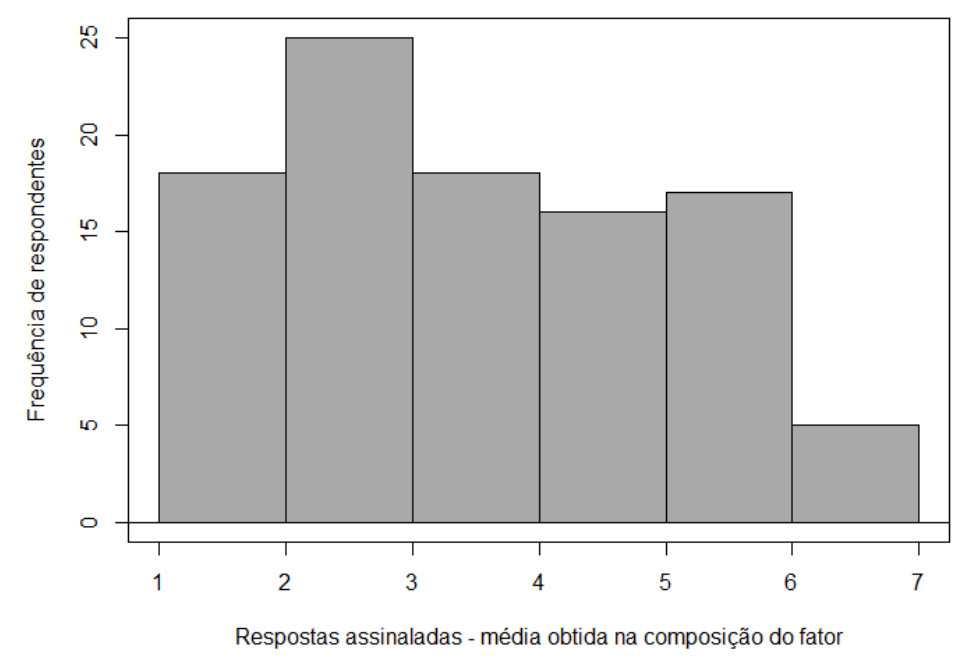

Fonte: autor da dissertação

Assim, verifica-se que a maioria dos participantes em ambos os grupos não possui este tipo de medo, apesar de ele ser descrito nos relatórios dos encontros do Comitê Nacional [7, 25] e do OIEA [1]. No Grupo 2, a ausência deste fator era esperada em menor proporção, ou com maior quantidade de indecisão, já que os participantes não conhecem bem o meio empresarial do negócio por não participarem dele diretamente. Com a maioria de indecisões e ausência de medo, conclui-se que a não adesão de transportadores de produtos perigosos ao transporte também da classe 7 , que causa indisponibilidade de transportadoras, está mais relacionada ao medo de problemas de saúde e acidentes que o medo de prejuízo de imagem social. 
No Grupo 1, apesar de os prejuízos serem presentes e mostrados no Gráfico 8, não geram medo na maioria dos participantes, indicando que este não é um impeditivo para permanecer no transporte da classe 7.

A Tabela 15 compara a distribuição de média geral e de quartis para ambos os grupos no fator 2. O valor $p$ para esta análise em ambos os grupos foi menor que 0.01 .

\section{Tabela 15 - Resumos numéricos dos Grupos 1 e 2 para o fator 2}

\begin{tabular}{|c|c|c|}
\hline Fator de análise & Grupo 1 & Grupo 2 \\
\hline Média geral & 2,82 & 3,59 \\
\hline $\begin{array}{l}1^{\circ} \text { quartil, } 25 \% \\
\text { da frequência }\end{array}$ & 1,45 & 2,40 \\
\hline $\begin{array}{l}2^{\circ} \text { quartil, } 50 \% \\
\text { da frequência }\end{array}$ & 2,30 & 3,60 \\
\hline $\begin{array}{l}3^{\circ} \text { quartil, } 75 \% \\
\text { da frequência }\end{array}$ & 3,80 & 5,0 \\
\hline
\end{tabular}

Fonte: autor da dissertação.

A média geral do Grupo 1 indica a ausência do medo ou medo fraco de prejuízo a imagem social, enquanto a média geral do Grupo 2 indica indecisão. Analisando os quartis, percebe-se que a maioria do Grupo 1 (75\%) encontra-se no intervalo de ausência de medo ou no início do intervalo de indecisão $(<3,80)$, confirmando a conclusão formulada anteriormente. Já o Grupo 2 encontra-se minoritariamente no intervalo de presença de medo, e majoritariamente nos intervalos de indecisão ou ausência de medo, indicando, novamente, que o medo de prejuízo a imagem social não é um fator relevante para recusas e demoras e para a indisponibilidade de transportadoras. Claramente, uma análise da motivação geral de indisponibilidade e de ocorrência de problemas não deve considerar somente o fator de medo, mas sim todos os outros aspectos, como descrito ao longo desta dissertação. 


\section{DISCUSSÃO E SUGESTÃO DE SOLUÇÕES}

\subsection{Sugestões para resolução dos problemas do transporte aéreo}

Como descrito no subcapítulo 4.3.4.1, uma das dificuldades apontadas no transporte aéreo de material radioativo é a disposição dele dentro de aeronaves pequenas. Para este impeditivo, talvez a solução fosse buscar a disponibilidade de transporte entre as empresas que realizam somente o transporte comercial de cargas, para as quais as exigências de disposição no porão não são tão restritivas se comparadas às do transporte de passageiros [4, 17]. Segundo a ANAC, existem 12 empresas aéreas para o transporte regular de cargas e uma de transporte não regular [67].

Para cargas que não possuam uma periodicidade bem definida e com meiavida mais longa, esta opção é atrativa. Porém, no caso do transporte de radiofármacos, a periodicidade dos voos é um ponto chave para a possibilidade do negócio. Os radiofármacos possuem certa regularidade em sua produção e uso pelas clínicas diagnósticas. O tempo decorrido da produção e transporte até a chegada ao usuário é bem delimitado por causa dos horários de atendimento dos pacientes e curta meia-vida do material. Assim, voos regulares em certos horários facilitam o transporte. Porém, estes voos regulares e com maior periodicidade são característicos de aeronaves de passageiros. Logo, para o transporte de radiofármacos, a diversificação do transporte por meio das empresas de transporte de cargas tem de ser analisada com maior cautela, mas ainda se apresenta interessante.

No caso do problema em relação ao IT e distanciamento de $1 \mathrm{~m}$ do teto do porão, um estudo sobre a capacidade do teto do porão (ou piso dos passageiros) de blindar a radiação seria válido para que esta distância não precise ser considerada no momento de dispor o embalado. Pode-se verificar um IT máximo para o qual o teto do porão ofereça uma barreira à radiação do embalado transportado. Estando o embalado com IT igual ou inferior àquele, a distância até o teto poderia ser desconsiderada. Obviamente, o IT teria de obedecer ao propósito de limitar a exposição dos trabalhadores que transportam o embalado. Porém, a certificação de blindagem pelo teto do porão poderia facilitar a disposição dos embalados em aeronaves menores. 


\subsection{Comunicação e divulgação de informação}

O problema nas comunicação e divulgação de informação de ocorrências de recusas e demoras no transporte de materiais radioativos foi descrito no subcapítulo 4.3.1. Como a forma de divulgação sugerida pelo OIEA e pelo Comitê Nacional [7] não tem demonstrado resultados por ser econômica e estrategicamente desinteressante para as empresas, o ideal seria modificar o modelo de relatos e de sua divulgação.

Inicialmente, deve-se garantir o anonimato das informações coletadas e divulgadas. O levantamento de ocorrências e sua contabilização correta são importantes para avaliar a situação nacional e elaborar estratégias de solução. $O$ formulário oficial (ANEXO 1) é adequado para esta finalidade. Assim, seu preenchimento e envio para um órgão regulatório, como a CNEN, ainda deve ser estimulado. Porém, ele não serve para a finalidade de divulgação de informação ou alerta, pelos motivos anteriormente citados.

Com isso, a divulgação da informação deve ser resumida a tópicos como:

a) Motivo causador da recusa e atraso. Exemplos: incompatibilidade documental, erro na classificação de material por má interpretação, falta de sinalização obrigatória por conflito de normas, exigência excessiva de proteção radiológica etc;

b) Modal de ocorrência: aéreo, marítimo ou terrestre. Indicando também em qual etapa o erro ocorreu: recebimento, despacho, fiscalização, carregamento etc;

c) Procedimento correto a ser seguido.

A divulgação dessas informações periodicamente em uma rede de interessados ajuda a prevenir que erros conhecidos aconteçam novamente, criando um alerta para situações recorrentes. A divulgação pode ser realizada por e-mail e, idealmente, pelo mesmo responsável pelo recebimento do relato completo, que seria um órgão regulatório. Assemelhar-se-ia a um boletim informativo. A seguir, são dados exemplos do documento idealizado. 


\section{Exemplo 1}

"Durante o mês de março, foram contabilizadas duas demoras e uma recusa no transporte da classe 7 .

A recusa foi pela indisponibilidade de transportadoras marítimas na rota $X$, alterada recentemente, fazendo com que os navios necessitem de atracação no porto Y, que não aceita a classe 7. Um trabalho contínuo de novas rotas e transportadoras marítimas habilitadas deve ser realizado, assim como previsto pelo plano de ação do Comitê Nacional. As duas demoras ocorreram por uma incompatibilidade na classificação do material radioativo $Z$, transportado por via aérea. A norma CNEN e a norma ANAC diferem entre si na classificação do material e colocação do número ONU. Assim, orienta-se utilizar a classificação indicada na norma ANAC enquanto a atualização da norma CNEN não for divulgada."

\section{Exemplo 2}

"A polícia militar rodoviária tem aplicado multas pela sinalização de transporte incompatível com a norma da ABNT, atualizada em 2017. Apesar de os símbolos estarem de acordo com a norma da CNEN, orientamos a compra da nova norma ABNT e adequação aos seus padrões, já que os fiscais se guiam por esta última e não existem meios de sobreposição entre normas federais."

Esta medida encontra dificuldades na disponibilidade de recursos humanos e financeiros para sua realização, como descrito no item 3.6.

\subsection{O problema regulamentar e burocrático}

A excessividade de regulamentações vigentes no transporte de materiais radioativos parece ser um dos maiores problemas do país. A única solução razoável para tal excessividade é a redução da quantidade de regulamentos. Não se propõe reduzir as exigências realizadas pelos diversos órgãos separadamente, ou anular a atribuição legal de um ou outro órgão, já que isso contradiz as leis já publicadas e significaria um trabalho burocrático quase impossível na realidade nacional. Mas harmonizar e criar um documento único de regulamentação em âmbito federal. Em consulta a advogada Kelly José Moreschi, credenciada pela Organização dos Advogados do Brasil (OAB) sob o registro profissional no 307315, esta explica que a 
ação pode ser realizada e não encontra impeditivos legais, podendo ser feita da mesma forma que se realiza a consolidação de um conjunto de normas de um mesmo órgão. Mesmo não reduzindo as exigências, uma norma única útil a todos os interessados tem o potencial de reduzir os problemas de divergência e má interpretação causados pela regulamentação vigente.

Apesar da burocracia exaustiva presente na política nacional, o Brasil parece ter experiência e condições propícias a esta ação. Para embasamento, a CNEN, como dito anteriormente, realizou um termo de referência conjunto com o IBAMA, que não anulou as normas ou resoluções específicas dos órgãos, mas harmonizou ambas e facilitou a interpretação das exigências. Há intenção de incluir neste documento outros órgãos normativos, mas isto ainda não ocorreu. Este não se trata de um documento regulamentar, mas sim, um guia. Outro exemplo de harmonização deu-se pela ANTT, que faz referência direta a norma da CNEN para cumprimento das exigências durante o transporte terrestre da classe 7. Percebe-se que os diversos órgãos normativos estão entrosados e aplicados em harmonizar suas regulamentações, graças ao trabalho do Comitê Nacional. Logo, a criação de uma norma única parece razoável.

A articulação desta ação encontra impeditivo ou dificuldade por causa do problema de indisponibilidade de recursos financeiros e humanos, como já descrito anteriormente. Algumas questões que podem ser levantadas neste caso e possíveis respostas para elas são:

a) Arrecadação da multa: se o documento é único e vigente a todos os órgãos, quem receberia o valor aplicado em multas pelo seu descumprimento? Facilmente, o valor arrecadado pode ser repassado ao órgão do fiscal da autuação. As instituições permanecerão independentes, assim como seus fiscais. O órgão que realizar a autuação fica responsável pela arrecadação da multa;

b) Exigências específicas do modal: alguns modais possuem exigências específicas que não entrariam em uma norma geral. Neste caso, basta incluí-las em uma seção ou capítulo separados do documento. Diversos aspectos são comuns a todos os órgãos e serão favorecidos pela padronização, como 0 cálculo de IT, uso no número ONU, simbologia, classificação dos materiais, 
plano emergencial, entre outros. Requisitos específicos para um modal ou situação podem ser tratados em capítulos diferentes do documento;

c) Extensão do documento: consolidar todas as normas pode resultar em um documento deveras extenso. Porém outros documentos internacionais como o Livro Laranja (Orange Book) e o código IMDG (IMDG code) também o são e funcionam perfeitamente.

Como vantagem, essa ação traria:

a) Harmonização entre as regulamentações nacionais vigentes, com potencial de harmonização internacional, já realizada por algumas instituições;

b) Criação de um grupo de trabalho altamente qualificado, garantindo que todos os aspectos de segurança sejam considerados pelo ponto de vista de diferentes especialistas;

c) Redução dos problemas de má interpretação ou interpretação ambígua, já que não há mais necessidade de interpretar documentos diferentes e separados;

d) Facilidade de acesso à legislação, já que o transportador, expedidor ou outro interessado no transporte não precisará acessar diferentes órgãos e normas para garantir o conteúdo necessário.

Este seria o cenário legislativo ideal. Porém, enquanto não se cumpre, a continuidade do trabalho realizado pelo Comitê Nacional descrito no capítulo 6 é de fundamental importância.

\subsection{0 problema educacional}

O principal fator que causa recusas e demoras no transporte dentro do aspecto da educação é a má formação ou informação de agentes fiscais e outros funcionários envolvidos no recebimento e na liberação do material radioativo. A solução é melhorar o treinamento destes profissionais, fazendo com que informações importantes sobre a classe 7 e suas legislações sejam incluídas na grade curricular de forma obrigatória.

Como cada modal e órgão possui seu próprio curso de formação, alterar a todos individualmente é uma tarefa difícil, demorada e burocrática. Além disso, os 
conhecimentos necessários variam de acordo com o cargo do funcionário. Pensar em uma formação extensa que envolva todas a normas e seus aspectos, como aquela realizada por especialistas na classe 7 , não é uma opção economicamente viável e nem necessária na maioria dos casos. Um motorista, por exemplo, não tem a necessidade de conhecer todas as exigências de proteção radiológica e classificação de um embalado, mas precisa conhecer os documentos a serem transportados, procedimentos de emergência específicos e sinalização do veículo. Já um fiscal rodoviário ou aeroportuário precisa conhecer os documentos exigidos em legislação para o transporte e seu detalhamento, requisitos de segurança como o IT, sinalização correta, licenças necessárias, entre outros. Para que estas informações sejam passadas a estes profissionais de forma correta, inclusive com a exposição de divergências entre normas, sugere-se:

1. Modificar a grade curricular de cursos já existentes para estes profissionais com acompanhamento do Comitê Nacional.

Como os cursos variam de acordo com o modal e com a instituição, esta medida dificilmente seria implementada por completo. O tempo para alcançá-la também pode ser muito longo, já que depende de diferentes instituições. Para aquelas que realizam revisões e atualizações regulares, como a ANAC, o processo é facilitado. Porém esta não é a realidade de todos os casos. Algumas instituições, como a Polícia Militar e a Polícia Rodoviária Federal, por exemplo, possuem capacitações específicas para fiscalização de cargas perigosas. Mas por se tratarem de instituições militares, o acesso ao conteúdo e à sua modificação podem ser dificultados. São instituições que, por exemplo, não participam do Comitê Nacional.

2. Montar um curso ou uma apostila didática sobre o transporte de materiais radioativos de forma complementar aos cursos já existentes exigidos em norma, com informações voltadas para cada uma das funções envolvidas no transporte. O material deve ser desenvolvido por especialistas no transporte da classe 7 de diferentes modais e instituições, como aqueles presentes no Comitê Nacional, afim de contemplar as diversas normas e aspectos práticos. Esta medida encontra dificuldades por falta de recursos humanos e financeiros, especialmente dos órgãos públicos, inclusive se considerarmos que o conteúdo deverá acompanhar a modificação das normas ao longo do tempo. No cenário 
nacional, a maior probabilidade de sucesso é que este trabalho seja feito por estudantes de mestrado ou doutorado, em forma de dissertação ou tese, que pode ou não render uma patente, e seja mantido ou atualizado por um órgão regulatório.

Este conteúdo pode ser referenciado pelas atualizações das normas em vigor, de forma similar ao realizado pela ANTT. Assim, alterações extensas no texto de cada uma das normas não se tornaria necessário.

Já a educação e fornecimento de informações em âmbito nacional encontra dificuldades ainda maiores. Será necessário não só a inclusão do tema de radiações ionizantes e suas aplicações nos ensinos fundamental e médio, mas também a formação dos professores que lecionarão a disciplina. Propõe-se, inicialmente, focar na qualificação dos docentes, já que estes possuem na rede pública de ensino incentivos a formação continuada e abertura para atividades extracurriculares desenvolvidas no ambiente de trabalho. Posterior ou simultaneamente a esta medida, a grade curricular dos ensinos fundamental e médio deverão ser alteradas para incluir seus assuntos de forma harmônica com outros conteúdos e no período propício a esta aprendizagem.

\subsection{Medo da radiação ionizante no transporte}

Como exposto no capítulo 7, o principal medo para os não especialistas no transporte da classe 7 é o de problemas com a saúde e com os acidentes. O único meio de amenizar o medo é através do fornecimento de informações acerca da segurança do transporte dos materiais radioativos. Esta medida pode ser alcançada se implementadas as mudanças descritas no subcapítulo 8.4. Ela fará com que as informações necessárias sejam incluídas nos cursos para formação de profissionais relacionados ao transporte de produtos perigosos em geral. Até a sua implementação, a explanação do assunto pelos docentes destes cursos é fundamental para reduzir a percepção errônea sobre a segurança no transporte da classe 7 . 


\section{CONCLUSÕES}

As recusas e demoras no transporte de materiais radioativos não possuem uma solução única e nem soluções que podem ser aplicadas a um conjunto grande de casos. O problema é extenso e heterogêneo e envolve a legislação, a educação nacional, a educação e capacitação específicas e a viabilidade econômica para o transportador, para o produtor e expedidor de materiais radioativos. Muitos fatores não estão sob a influência dos órgãos regulatórios ou dos membros do Comitê Nacional. Assim, a previsão para que todos os casos sejam solucionados não existe neste momento. Os casos que geram prejuízos mais graves devem e são tratados com prioridade. Além disso, há a mutabilidade dos problemas ao longo do tempo. A atualização de normas, de rotas de transporte, do cenário econômico nacional e mundial influenciam diretamente na ocorrência de recusas e demoras.

Ainda assim, o esforço conjunto de um grupo de interessados, como o Comitê Nacional, a divulgação de informação e a comunicação são os fatores que mais demonstraram avanços na resolução ou redução das ocorrências de recusa e demora. A harmonização entre as legislações e a captação de representantes de instituições públicas e privadas devem ser contínuas e, se possível, expandidas. O Brasil adquiriu experiência e apresentou resultados relevantes nos últimos 9 anos. O levantamento de recursos financeiros e humanos para continuidade e expansão do Comitê Nacional e suas ações é crucial para a redução significativa dos problemas a médio prazo e sua extinção a longo prazo.

O medo da radiação ionizante, que prejudica não só o transporte, mas todas as aplicações que dependem do uso das radiações, tem sua extinção dependente de mudanças na educação nacional e divulgação de informação. O escritor estadunidense Howard Phillip Lovecraft escreveu que "a emoção mais antiga e mais forte da humanidade é o medo, e o mais antigo e o mais forte dos medos é o medo do desconhecido". O desconhecimento sobre as radiações, suas aplicações e segurança gera percepções errôneas e, consequentemente, medo. Mudanças na base curricular dos ensinos fundamental e médio somadas a medidas de divulgação de informação em massa são os meios mais rápidos para promover a extinção do problema. Porém, são ações que não dependem diretamente dos especialistas em radiação ionizante, mas 
de membros do governo, de educadores e da mídia, que também desconhecem o assunto em uma maioria de casos. Assim, o esforço inicial corresponde ao acesso a estas pessoas e suas sensibilização e informatização, para que medidas comecem a ser aplicadas em âmbito nacional. O trabalho é extenso e moroso, mas possui o potencial de melhorar significativamente o mercado de aplicações das radiações ionizantes no país. 


\section{TRABALHOS FUTUROS}

1. Apresentar e discutir os resultados obtidos nos seis campos de ação mencionados no subcapítulo 6.1 , bem como examinar se podem ser extraídas conclusões.

2. Investigar se o Comitê Nacional terá uma longa e contínua duração ou é previsível que em um futuro próximo os problemas de demora e recusa cessem.

3. Como o nosso parque industrial de aplicações das radiações ionizantes ainda é muito incipiente para abraçar o grau de extensão territorial do nosso país, há possibilidade de que este cresça para atender o crescimento da demanda nacional. Assim, há necessidade de investigar se as atuais redes de transportes terrestres, aéreas e aquáticas estão adequadas para atender esta nova demanda ou deverão ser expandidas.

4. Identificar e sugerir medidas educacionais sobre tecnologia nuclear que podem ser aplicadas no ensino fundamental, médio e superior, a fim de reduzir o medo de radiação do público e melhorar a opinião pública sobre as aplicações da radiação ionizante.

5. Se as grades curriculares dos cursos específicos exigidos em norma não forem alteradas, montar um curso ou uma apostila didática sobre o transporte de materiais radioativos de forma complementar a estes, com informações voltadas para cada uma das funções envolvidas no transporte. Esta ação tem maior probabilidade de sucesso, considerando o cenário nacional, se realizada em forma de dissertação ou tese, por alunos de mestrado e doutorado. 


\section{REFERÊNCIAS}

[1] INTERNATIONAL ATOMIC ENERGY AGENCY, Safety of Trasport of Radioactive Material: Proceedings of an international conference Vienna, 7-11 July 2003. Vienna:2003.

[2] WORLD NUCLEAR TRANSPORT Sustaining shipments of radioactive materials.
<https://www.wnti.co.uk/media/13813/5.pdf>. Acessado em 12/02/2019. INSTITUTE,

[3] UNITED NATIONS, Transport of Dangerous Goods, Vol. 1. New York and Geneva: 2017.

[4] COMISSÃO NACIONAL DE ENERGIA NUCLEAR, Transporte de Materiais Radioativos. Resolução CNEN 013/88, Norma CNEN NE 5.01, 1988.

[5] AGÊNCIA NACIONAL DE TRANSPORTES TERRESTRES, Resolução ํㅜ 420 de 12 de Fevereiro de 2004, 2004.

[6] AGÊNCIA NACIONAL DE TRANSPORTES TERRESTRES, Resolução ํㅜ 2.657 de 15 de Abril de 2008, 2008.

[7] COMITÊ BRASILEIRO SOBRE RECUSAS E DEMORAS NO TRANSPORTE DE MATERIAIS NUCLEARES E OUTROS MATERIAIS RADIOATIVOS, Relatório do Primeiro Encontro e Plano de Ação Nacional. São Paulo: 2010.

[8] COMISSÃO NACIONAL DE ENERGIA NUCLEAR, Normas. Disponível em: <http://www.cnen.gov.br/normas-tecnicas>. Acessado em 25 de abril de 2018.

[9] OKUNO, E., Efeitos biológicos das radiações ionizantes: acidente radiológico de Goiânia. Estud. av., São Paulo, v. 27, n. 77, p. 185-200, 2013. Disponível em: $<$ http://www.scielo.br/scielo.php?script=sci_arttext\&pid=S0103-

$40142013000100014 \&$ Ing=en\&nrm=iso $>$. Acessado em 25 de abril de 2018.

[10] COMISSÃO NACIONAL DE ENERGIA NUCLEAR, Diretrizes básicas de proteção radiológica, NN 3.01, março de 2014. 
[11] Efeito da Radiação lonizante em Células, aula da matéria TNA 741 do Instituto de Pesquisas Energéticas e Nucleares. Disponível em: < https://www.ipen.br/portal_por/portal/interna.php?secao_id=132>. Acessado em 10/03/2019.

[12] COMISSÃO NACIONAL DE ENERGIA NUCLEAR, Princípios da Segurança Nuclear. Disponível em: < https://www-ns.iaea.org/downloads/ni/embarking/ws-ssg16brazil-2011 oct/17-oct-monday/seguranca-nuclear-conceptos-basicos.pdf>. Acessado em 10/03/2019.

[13] COMISSÃO NACIONAL DE ENERGIA NUCLEAR, Gerência de rejeitos radioativos de baixo e médio níveis de radiação, NN 8.01, abril de 2014.

[14] SEKARAN, U., Research Methods for Business: A Sikill-Building Aproach. Southern Illinois University at Carbondale. $4^{\mathrm{a}}$ ed. 2003.

[15] CONSELHO NACIONAL DE TRÂNSITO, Resolução 168 de 2004.

[16] Código Brasileiro de Trânsito, Artigo 145, 2º edição. Brasília: 2009.

[17] AGÊNCIA NACIONAL DE AVIAÇÃO CIVIL, RBAC no 175, emenda ํo 1, 25 de janeiro de 2018.

[18] AGÊNCIA NACIONAL DE AVIAÇÃO CIVIL, Treinamento de Artigos Perigosos. Disponível em: <http://www.anac.gov.br/assuntos/passageiros/artigoperigoso1/treinamento-de-artigos-perigosos>. Acessado em 12/02/2019.

[19] INTERNATIONAL MARITIME ORGANIZATION, International Maritime Dangerous Goods Code, edição 2016, 2016.

[20] ANDERSON, D. R.; SWEENEY, D. J. \& WILLIANS, T. A., Estatística aplicada a administração e economia. Tradução de Luiz Sérgio de Castro Paiva, $2^{\circ}$ edição. Pioneira Thomson Learning. São Paulo, 2002.

[21] INTERNATIONAL ATOMIC ENERGY AGENCY, IAEA Regional Workshop on Denials of Shipment of Radioactive Material for Asia and Pacific - Final Report. Beijing, China: 2008. 
[22] GRAY, P., Regional Workshop of Safe Transport of Radioactive Material in the Caribbean: Module 4.6, Denial of Shipment. International Atomic Energy Agency Meeting, Panama, 2014.

[23] INTERNATIONAL ATOMIC ENERGY AGENCY, Regional Workshop Denials of Shipment of Radioactive Material European Commission: Luxembourg - Meeting Report, 17-19 de junho de 2009.

[24] ORGANISMO INTERNACIONAL DE ENERGÍA ATÓMICA, Taller Regional sobre el Rechazo de Expediciones de Materiales Radiactivos, Montevideo. Sem data indicada. Disponível em: < https://www-ns.iaea.org/downloads/rw/transportsafety/denial-shipments/montevideo-final-report.pdf>. Acessado em 10/03/2019.

[25] COMITÊ BRASILEIRO SOBRE RECUSAS E DEMORAS NO TRANSPORTE DE MATERIAIS NUCLEARES E OUTROS MATERIAIS RADIOATIVOS, Relatório do Segundo Encontro e Atualização do Plano de Ação Nacional. Rio de Janeiro: 2010.

[26] TORRES, M. D. F., Estado, democracia e administração pública no Brasil, Ed. FGV, Rio de Janeiro: 2004.

[27] UNITED NATIONS, Transport of dangerous goods: model regulations, 20aㅡ edição, 2017.

[28] INTERNATIONAL CIVIL AVIATION ORGANIZATION, Technical Instructions for the Safe Transport of Dangerous Goods by Air, edição 2017-2018, 2017.

[29] SENADO FEDERAL, Constituição da República Federativa do Brasil, 1988.

[30] PRESIDÊNCIA DA REPÚBLICA, Lei no 6.938, 31 de agosto de 1981.

[31] CONSELHO NACIONAL DO MEIO AMBIENTE, Resolução oㅜ 237, 19 de dezembro de 1997.

[32] INSTITUTO BRASILEIRO DO MEIO AMBIENTE E DOS RECURSOS NATURAIS RENOVÁVEIS; COMISSÃO DE NACIONAL DE ENERGIA NUCLEAR, Base Para Reformulação do Termo de Referência para o Controle da Atividade de Transporte de Materiais Radioativos e Operacionalização do Sistema Nacional de Transporte de Produtos Perigosos, Nota Técnica Conjunta IBAMA-CNEN01/2013, 2013. 
[33] PRESIDÊNCIA DA REPÚBLICA, Lei Complementar ㄲo 140, 8 de dezembro de 2011.

[34] INSTITUTO BRASILEIRO DO MEIO AMBIENTE E DOS RECURSOS NATURAIS RENOVÁVEIS, Instrução Normativa ํo 5, 9 de maio de 2012.

[35] INSTITUTO BRASILEIRO DO MEIO AMBIENTE E DOS RECURSOS NATURAIS RENOVÁVEIS, Transporte Marítimo e Interestadual de Produtos Perigosos. Disponível

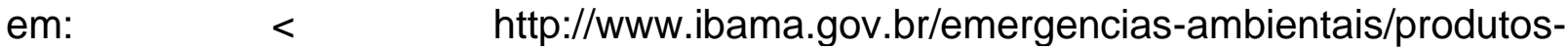
perigosos/transporte-maritimo-e-interestadual-de-produtos-

perigosos\#sobreaautorizacao >. Acessado em 04/04/2018.

[36] PRESIDÊNCIA DA REPÚBLICA, Lei no 10.233 de 5 de junho de 2001.

[37] AGÊNCIA NACIONAL DE TRANSPORTES TERRESTRES, Resolução 5.232 de 14 de dezembro de 2016.

[38] AGÊNCIA NACIONAL DE TRANPORTES TERRESTRES, Aviso de audiência pública ำ 4/2016.

[39] AGÊNCIA NACIONAL DE TRANSPORTES TERRESTRES, Despacho-Processo 50500.056919/2015-80, Compatibilização da Resolução ANTT no 420, de 31 de julho de 2004, à 18ª edição do Orange Book, julho de 2015.

[40] INTERNATIONAL ATOMING ENERGY AGENCY, Regulations for the safe transport of radioactive material, Specific Safety Requirements no SSR-6, Rev. 1, 2018.

[41] ASSOCIAÇÃO BRASILEIRA DE NORMAS TÉCNICAS, NBR 7500: Identificação para o transporte terrestre, manuseio, movimentação e armazenamento de produtos, 2018.

[42] PREFEITURA DO MUNICÍPIO DE SÃO PAULO, Decreto no 50.446, São Paulo, 20 de fevereiro de 2009.

[43] COMISSÃO NACIONAL DE ENERGIA NUCLEAR, Instalações Autorizadas. Disponível em: <http://www.cnen.gov.br/instalacoes-autorizadas>. Acessado em 02/10/2018. 
[44] PREFEITURA DO MUNICÍPIO DE SÃO PAULO, Valores das taxas e tributos para autuação de processo para alvará de autorização para eventos temporários e suas renovações, Secretaria Municipal de Urbanismo e Licenciamento, 2017.

[45] ASSEMBLEIA LEGISLATIVA DE MINAS GERAIS, Lei 22.805 de 29 de dezembro de 2017.

[46] PRESIDÊNCIA DA REPÚBLICA, Lei no 12.815 de 5 de junho de 2013.

[47] AGENCIA NACIONAL DE TRANSPORTES AQUAVIÁRIOS, Resolução n 2239 de 15 de setembro de 2011.

[48] COMISSÃO NACIONAL DE ENERGIA NUCLEAR, Certificação da qualificação de supervisores de proteção radiológica. Norma CNEN NN 7.01 de maio de 2016.

[49] PRESIDÊNCIA DA REPÚBLICA, Decreto ํㅜ 3665 de 20 de novembro de 2000.

[50] CENTRAL INTELLIGENCE AGENCY, The world FactBook. Disponível em: $<$ https://www.cia.gov/library/publications/the-world-factbook/geos/br.html>. Acessado em 26/09/2018.

[51] COMITÉ BRASILEIRO SOBRE RECUSAS E DEMORAS NO TRANSPORTE DE MATERIAIS NUCLEARES E OUTROS MATERIAIS RADIOATIVOS, Relatório do terceiro encontro e atualização do plano de ação nacional, Rio de Janeiro: 27 de setembro de 2011.

[52] MINISTÉRIO DA EDUCAÇÃO; INSTITUTO NACIONAIS DE ESTUDOS E PESQUISAS EDUCACIONAIS ANÍSIO TEIXEIRA, Mapa do analfabetismo no Brasil. Disponível em:

http://portal.inep.gov.br/documents/186968/485745/Mapa+do+analfabetismo+no+Bras il/a53ac9ee-c0c0-4727-b216-035c65c45e1b?version=1.3>. Acessado em 10/03/2019.

[53] PISA: o Brasil ainda sofre para interpretar textos. Revista Época Educação. Redação de Flávia Yuri Oshima, 06/12/2016. Disponível em: <https://epoca.globo.com/educacao/noticia/2016/12/pisa-o-brasil-ainda-sofre-parainterpretar-textos.html >. Acessado em 02/03/2019. 
[54] LUCENA, E. A., et. Al., Radiação lonizante, Energia Nuclear e Proteção Radiológica para a Escola, Brazilian Journal of Radiation Sciences. Jan. 2017.

[55] MINISTÉRIO DA EDUCAÇÃO, Base Nacional Comum Curricular: Ensino Médio, 2017.

[56] AGÊNCIA NACIONAL DE AVIAÇÃO CIVIL, Instrução Suplementar nํ 175-002, Revisão E, 6 de julho de 2018.

[57] AGÊNCIA NACIONAL DE AVIAÇÃO CIVIL, Entidades de Ensino de Artigos Perigosos. Atualização 28/01/2019. Emitido pela Superintendência de Padrões Operacionais e Gerência Técnica de Artigos Perigosos. 2019.

[58] MARINHA DO BRASIL - DIRETORIA DOS PORTOS E COSTAS, Programa de Ensino Profissional Marítimo para Aquaviários 2019. 2019.

[59] MINISTÉRIO DA TRANSPARÊNCIA, Portal da Transparência: Comissão Nacional de Energia Nuclear. Disponível em: $<$ http://www.portaldatransparencia.gov.br/orgaos/20301-comissao-nacional-deenergia-nuclear>. Acessado em 02/10/2018.

[60] PORTAL BRASIL, Índice Geral de Preços - IGP - DI: Fundação Getúlio Vargas. Disponível em: <http://www.portalbrasil.net/igp.htm>. Acessado em 02/10/2018.

[61] Planejamento prevê retomada dos concursos públicos a partir de 2019. Redigido por Alexandro Martello, G1 notícias, 24/09/2017. Disponível em: < https://g1.globo.com/economia/concursos-e-emprego/noticia/planejamento-preveretomada-dos-concursos-publicos-a-partir-de-2019.ghtml . Acessado em 07/01/2019.

[62] RODRIGUES, D. L., Impacto Radiológico Devido ao Transporte de Radiofármacos do IPEN - CNEN/SP, Tese de Doutorado em Tecnologia Nuclear, Orientado por Dr. Gian-Maria A. A. Sordi, Universidade de São Paulo. São Paulo, 2009.

[63] MINISTÉRIO DO MEIO AMBIENTE; MINISTÉRIO DA JUSTIÇA; MINISTÉRIO DA CULTURA; MINISTÉRIO DA SAÚDE, Portaria Interministerial no 419, 26 outubro de 2011.

[64] PRESIDÊNCIA DA REPÚBLICA, Lei no 6.538 de 22 de junho de 1978. 
[65] KELCOM, A.; GOUVEA, R. C. S, A percepção de radioatividade por estudantes do nível superior. Mundo e Vida, vol. 3, p. 78-89, 2002.

[66] DUTRA, P. M. B. F., Percepção de estudantes do ensino médio sobre o tema "radiação" e tecnologias relacionadas: ideias informais e categorias conceituais. Centro de Desenvolvimento da Tecnologia Nuclear - CNEN. Dissertação de mestrado em Ciência e Tecnologia das Radiações, Minerais e Materiais. Orientado por Dr. Alexandre Soares Leal. Belo Horizonte, 2010.

[67] AGÊNCIA NACIONAL DE AVIAÇÃO CIVIL, Empresas Aéreas - Consulta. Disponível em $<$ https://sistemas.anac.gov.br/sas/empresasaereas/view/frmEmpresas.aspx>. Acessado em 26/09/2018. 


\title{
APÊNDICE A - Termo de Consentimento Livre e Esclarecido (TCLE)
}

\author{
UNIVERSIDADE DE SÃO PAULO \\ INSTITUO DE PESQUISAS ENERGÉTICAS E NUCLEARES \\ TERMO DE CONSENTIMENTO LIVRE E ESCLARECIDO
}

Prezado participante,

Convidamos o (a) Sr. (a) para participar da Pesquisa "Recusas e Demoras no Transporte de Materiais Radioativos" sob a responsabilidade da pesquisadora Daniela Campos, a qual pretende averiguar os principais motivos que acarretam recusas e atrasos no transporte de materiais radioativos no país e buscar soluções para o problema.

Sua participação é voluntária e se dará por meio de entrevista, na qual será aplicada um questionário. A duração do questionário é de aproximadamente 7 minutos se todas as questões forem preenchidas calma e atenciosamente.

Não há riscos significativos em participar desta pesquisa e você tem a opção de responder o questionário parcialmente, bem como as perguntas avulsas se forem realizadas. Se você aceitar participar, estará contribuindo para a provável diminuição na quantidade de recusas e demoras no transporte de materiais radioativos no país e, consequentemente, os impactos negativos que o problema acarreta.

Se depois de consentir em sua participação o Sr. (a) desistir de continuar participando, tem o direito e a liberdade de retirar seu consentimento em qualquer fase da pesquisa, seja antes ou depois da coleta dos dados, independente do motivo e sem nenhum prejuízo a sua pessoa. Isto quer dizer que o questionário pode ser interrompido a qualquer momento fechando a página, assim suas respostas não serão computadas. Se quiser retirar sua participação após o envio, entre em contato com o pesquisador pelos meios fornecidos abaixo. $\mathrm{O}$ (a) Sr. (a) não terá nenhuma despesa e também não receberá nenhuma remuneração. Essa pesquisa não prevê prejuízos financeiros ou de qualquer tipo aos seus participantes.

Os resultados da pesquisa serão analisados e publicados, mas sua identidade não será divulgada, sendo guardada em sigilo. O questionário é respondido de forma ANÔNIMA, logo, sua identificação pessoal não será recolhida ou divulgada. Para qualquer outra informação, o (a) Sr. (a) poderá entrar em contato com a pesquisadora no endereço Av. Prof. Lineu Prestes, 2242, Prédio da Gerência de Radioproteção Cidade Universitária, São Paulo - SP, pelos telefones (11) 3901-2545, (11) 98226-0070 e pelo e-mail dani_campos@live.com, ou poderá entrar em contato com o Serviço de Atendimento ao Cliente do Instituto de Pesquisas Energéticas e Nucleares - SAC/IPEN, na Av. Prof. Lineu Prestes, 2242, Prédio da Administração - Cidade Universitária, São Paulo - SP, telefone (11) 3133- 9161.

Ao responder este questionário, você concorda que foi informado sobre o que o pesquisador quer fazer e porque precisa da sua colaboração, e entendeu a explicação. Por isso, CONCORDA EM PARTICIPAR DO PROJETO, sabendo que não irá ganhar nada e que pode sair quando quiser. 


\section{APÊNDICE B - Questionário 1}

\section{RECUSAS E DEMORAS NO TRANSPORTE DE MATERIAIS RADIOATIVOS}

1. Como você está relacionado ao transporte de produtos perigosos?

a) Represento uma empresa que transporta produtos perigosos

b) Sou motorista e transporto produtos perigosos

c) Sou funcionário de uma empresa que transporta produtos perigosos

A próxima sequência de perguntas possui opções entre 1 a 7 . Assinale o quanto você concorda com a afirmativa. Sendo 1 caso você DISCORDE TOTALMENTE, e 7 caso você CONCORDE TOTALMENTE.

2. Um acidente envolvendo material radioativo tem maiores impactos do que outros materiais perigosos.

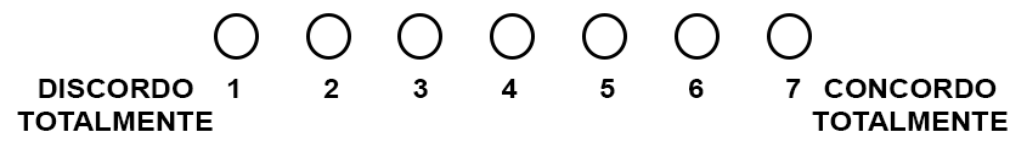

3. Um acidente com materiais radioativos traz mais riscos ao trabalhador do que outros materiais perigosos.

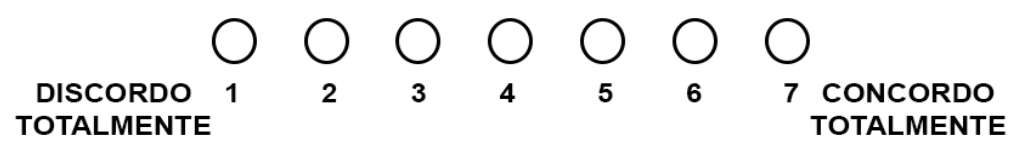

4. O transporte de material radioativo possui maior risco de acidentes.

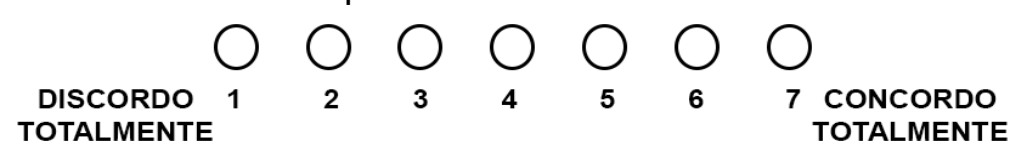

5. A segurança no transporte de materiais radioativos é menor do que a de outros materiais perigosos.

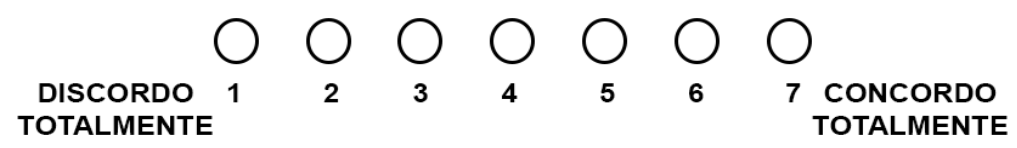

6. Me sentiria menos seguro em um acidente com material radioativo do que com outros materiais perigosos.

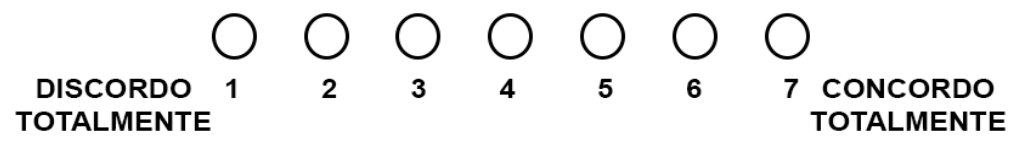

7. O transporte de material radioativo pode trazer problemas de saúde ao trabalhador.

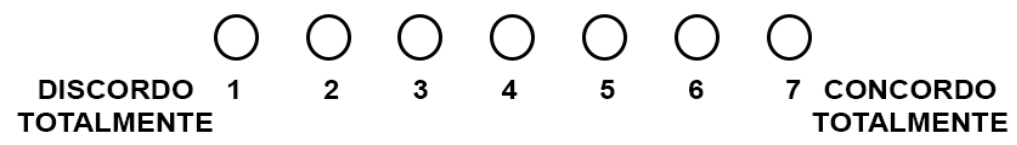

8. O transporte de materiais radioativos pode gerar problemas de saúde às pessoas próximas à via. 


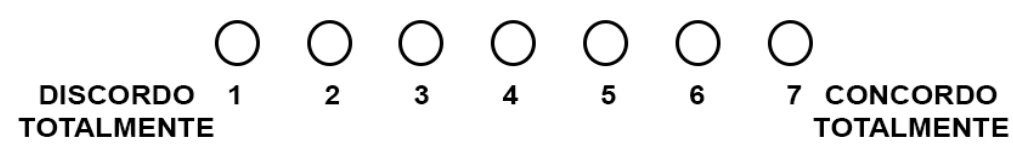

9. As consequências à saúde do trabalhador são piores no transporte de material radioativo.

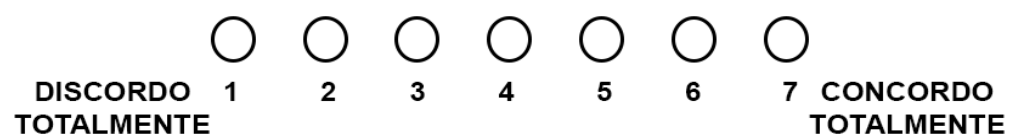

10. O transporte de material radioativo é mais insalubre que o de outros materiais perigosos.

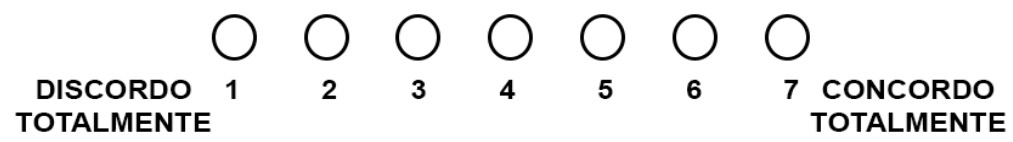

11. Pessoas que trabalham no transporte de material radioativo têm maior risco de desenvolver doenças.

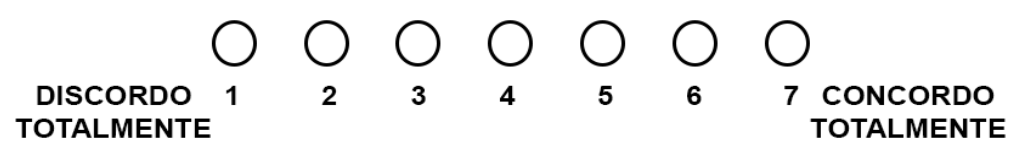

12. Os filhos das pessoas que trabalham com transporte de material radioativo possuem maior risco de nascer com problemas de saúde.

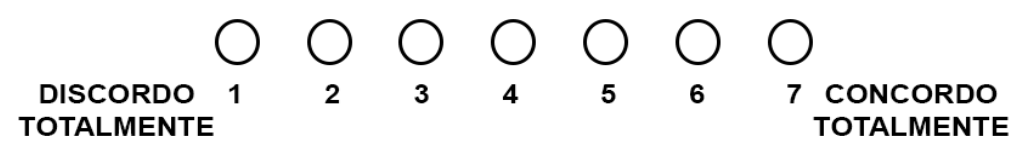

13. Empresas que trabalham com material radioativo não são bem vistas pela sociedade.

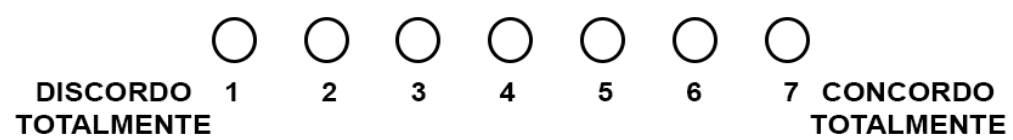

14. Empresas que trabalham com material radioativo têm sua imagem prejudicada.

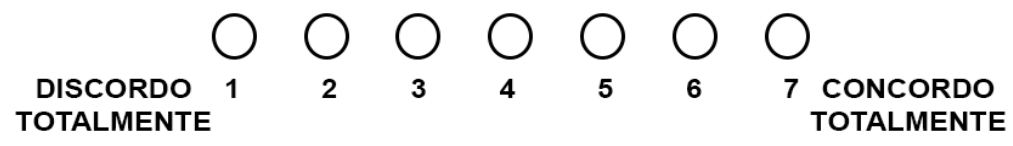

15. Transportar material radioativo pode fazer a empresa perder clientes.

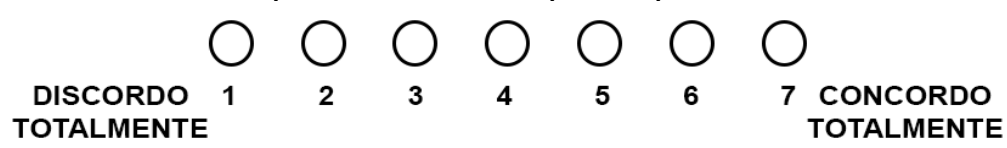

16. Transportar material radioativo faz com que as pessoas não queiram trabalhar na empresa.

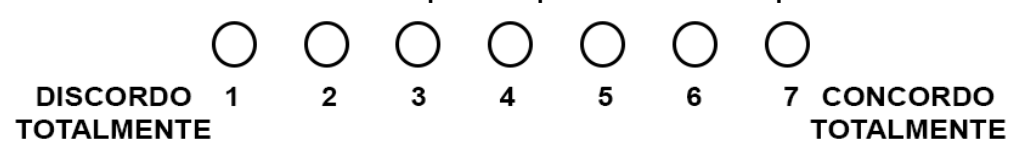

17. Transportar material radioativo faz com que a comunidade próxima à empresa se oponha a seu funcionamento.

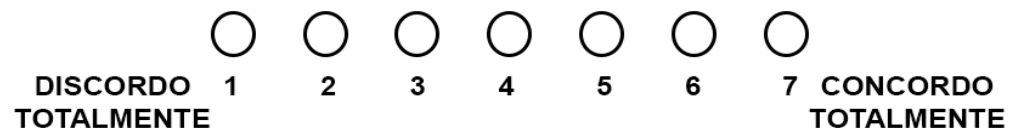




\section{APÊNDICE C - Questionário 2}

1. (Apenas transportadores) Assinale quais modais a empresa utiliza durante o transporte:

a) Terrestre

b) Aéreo

c) Marítimo

2. Considerando o serviço de transporte próprio e o fornecido por parceiros ou outras empresas, o material radioativo pelo qual a empresa é responsável sofre mais problemas no modal:
a) Terrestre
b) Aéreo
c) Marítimo

3. Considerando o cenário nacional e sua experiência, você acredita que a maior quantidade de recusas e demoras no transporte de material radioativo ocorre no modal:
a) Terrestre
b) Aéreo
c) Marítimo
d) Não tenho uma opinião sobre isto

4. Nos últimos 12 meses, quantos eventos de recusa ou demora ocorreram na empresa?
a) Nenhum evento
b) De 1 a 3 eventos
c) Mais de 3 eventos

5. Nos últimos 5 anos, quantos eventos de recusa ou demora ocorreram na empresa?
a) Nenhum evento
b) De 1 a 3 eventos
c) De 4 a 7 eventos
d) Mais de 7 eventos

6. (Apenas transportadores) Considere os motivos abaixo que podem acarretar a recusa ou demora no transporte de material radioativo e assinale com quais deles a empresa já teve que lidar.
a) Má interpretação da regulamentação vigente
b) Divergência entre diferentes regulamentações
c) Indisponibilidade de transportadora no período / percurso
d) Recusa do material pela transportadora auxiliar
e) Recusa do material pela autoridade competente no destino
f) Exigências excessivas (além da regulamentação vigente) na proteção ou outros aspectos durante o transporte

7. Quando ocorre uma recusa ou demora, o prejuízo financeiro para a empresa, geralmente:
a) Não ultrapassa o ganho que teria com a operação correta.
b) Equivale ao ganho que teria com a operação correta.
c) Ultrapassa o ganho que teria com a operação correta.

8. Além do prejuízo financeiro, assinale abaixo quais outras perdas que a empresa já sofreu por causa de recusas e demoras no transporte de material radioativo.
a) Prejuízo de imagem social
b) Perda de clientes
c) Redução da demanda de serviço pelo cliente
d) Perda de parcerias ou benefícios com outras empresas
e) Problemas com funcionários 


\section{ANEXO 1 - Formulário oficial para relato de recusas e demoras}

(continua)

\section{Report Form}

DIFFICULTIES ENCOUNTERED IN RELATION TO THE CARRIAGE OF

CLASS 7 DANGEROUS GOODS - RADIOACTIVE MATERIAL

\begin{tabular}{|c|c|}
\hline Report submitted by: ${ }^{1}$ & Date of Report (dd/mm/yyyy): \\
\hline \multicolumn{2}{|c|}{ Details of Product Shipped } \\
\hline \multicolumn{2}{|l|}{ Product name: } \\
\hline \multicolumn{2}{|l|}{ UN number: } \\
\hline Proper shipping name & RADIOACTIVE MATERIAL IN TYPE A PACKAGE \\
\hline Dangerous Goods Class or Division & 7 \\
\hline \multicolumn{2}{|l|}{ Shipment reference number (consignor ID) } \\
\hline The carriage of the above consignment was & delayed $\square$ \\
\hline
\end{tabular}

\begin{tabular}{|c|c|c|c|c|c|c|}
\hline \multicolumn{7}{|c|}{ Details of Consignment } \\
\hline \multicolumn{7}{|l|}{ Consignor } \\
\hline \multicolumn{7}{|l|}{ Consignee } \\
\hline \multicolumn{7}{|l|}{ Carrier } \\
\hline \multicolumn{2}{|l|}{ Mode of transport: } & Air $\square$ & Sea $\square$ & Rail $\square$ & Road $\square$ & Transit $\square$ \\
\hline \multicolumn{7}{|c|}{ Name of aircraft/ship/vehicle } \\
\hline \multicolumn{7}{|c|}{ Type of aircraft/ship/vehicle } \\
\hline \multicolumn{7}{|c|}{ Aircraft tail/IMO ship/vehicle identification number } \\
\hline \multicolumn{7}{|c|}{ Flight number/voyage reference/route reference } \\
\hline \multirow{2}{*}{$\begin{array}{l}\text { Location of loading: } \\
\text { (Airport/Port/Pickup) }\end{array}$} & City/Town/State & & & & & \\
\hline & Country & & & & & \\
\hline
\end{tabular}

\footnotetext{
${ }^{1}$ Name of Member Government's Civil Aviation, Maritime Administration or other Government Organisation or NonGovernmental Organization with consultative status, Manufacturer/Producer/Shipper submitting the Report.
} 


\begin{tabular}{|l|l|l|}
\cline { 2 - 3 } & Date & (continuação) \\
\hline Origin Airport/Port/City & \\
\hline Arrival Airport/Port/City & & \\
\hline
\end{tabular}

\begin{tabular}{||l|l||}
\hline \hline \multicolumn{2}{|c||}{ Details of Difficulty } \\
\hline Date of difficulty & \\
\hline Name of entity with whom the alleged difficulty & \\
\hline
\end{tabular}

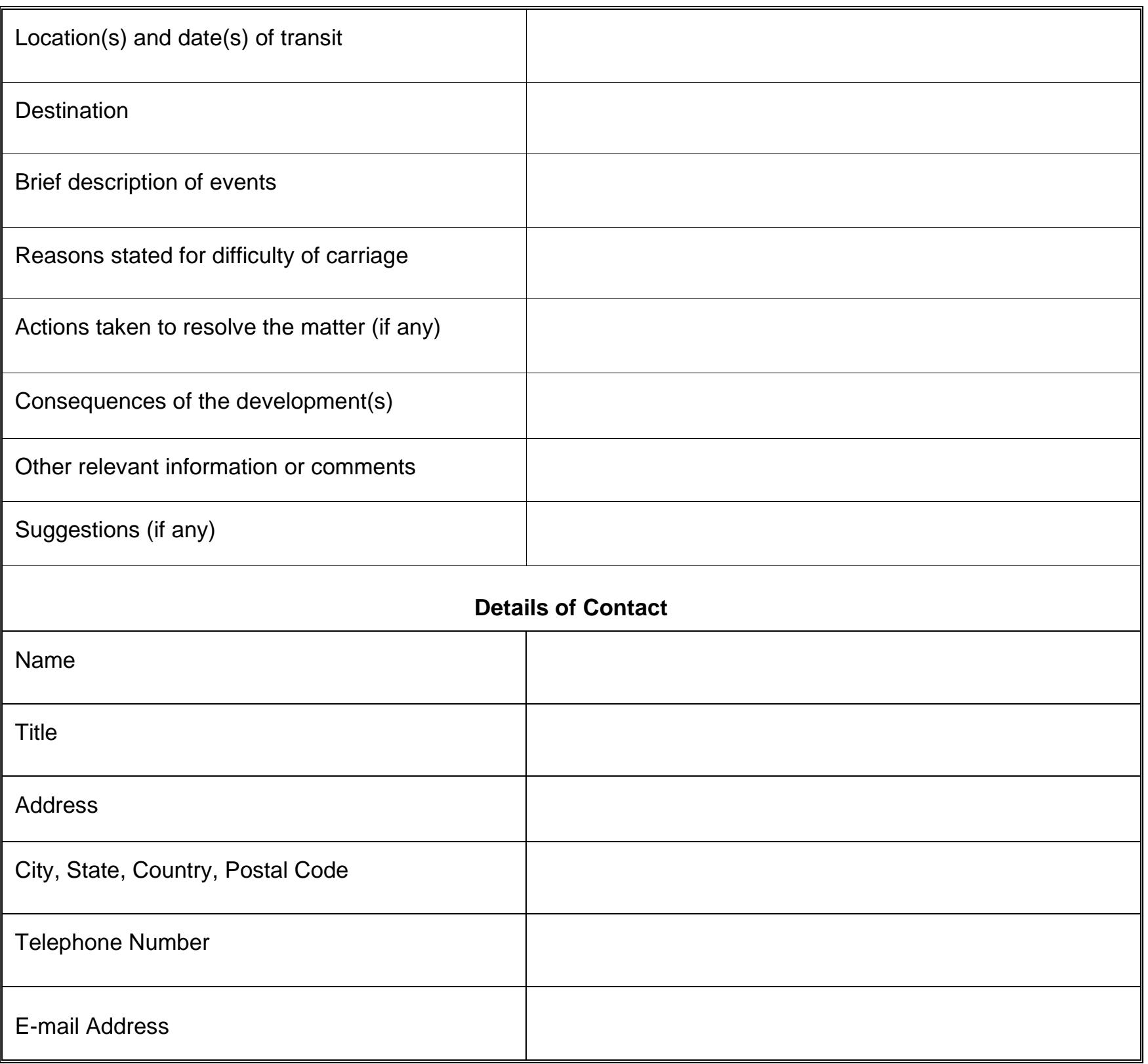




\section{ANEXO 2 - Grade curricular sugerida para o curso de artigos perigosos ANAC}

APÊNDICE A - CURRÍCULO SUGERIDO PARA O CURSO DE ARTIGOS PERIGOSOS

\begin{tabular}{|c|c|c|c|c|c|c|c|c|c|c|c|c|}
\hline \multirow{3}{*}{$\begin{array}{l}\text { Aspectos do transporte de artigos } \\
\text { perigosos por via aérea que devem } \\
\text { ser observados por todos os } \\
\text { envolvidos }\end{array}$} & \multicolumn{2}{|c|}{$\begin{array}{c}\text { Expedido- } \\
\text { rese } \\
\text { embalado- } \\
\text { res }\end{array}$} & \multicolumn{3}{|c|}{ Agências de carga } & \multicolumn{6}{|c|}{$\begin{array}{l}\text { Operadores aéreos que transporteam } \\
\text { artigos perigosos como carga ou mala } \\
\text { postal e agentes de manuseio em solo }\end{array}$} & \multirow[t]{2}{*}{$\begin{array}{l}\text { Agentes de } \\
\text { proteção }\end{array}$} \\
\hline & \multicolumn{11}{|c|}{ Categorias de funcionários } & \\
\hline & 1 & 2 & 3 & 4 & 5 & 6 & 7 & 8 & 9 & 10 & 11 & 12 \\
\hline Filosofia geral & $\mathrm{x}$ & $\mathrm{x}$ & $\mathrm{x}$ & $\mathrm{x}$ & $\mathrm{x}$ & $\mathrm{x}$ & $\mathrm{x}$ & $\mathrm{x}$ & $\mathrm{x}$ & $\mathrm{x}$ & $\mathrm{x}$ & $\mathrm{x}$ \\
\hline Limitações & $\mathrm{x}$ & & $\mathrm{x}$ & $\mathrm{x}$ & $\mathrm{x}$ & $\mathrm{x}$ & $\mathrm{x}$ & $\mathrm{x}$ & $\mathrm{x}$ & $\mathrm{x}$ & $\mathrm{x}$ & $\mathrm{x}$ \\
\hline Requisitos gerais para expedidores & $\mathrm{x}$ & & $\mathrm{x}$ & & & $\mathrm{x}$ & & & & & & \\
\hline Classificação & $\mathrm{x}$ & $\mathrm{x}$ & $\mathrm{x}$ & & & $\mathrm{x}$ & & & & & & $\mathrm{x}$ \\
\hline Lista de Artigos Perigosos & $\mathrm{x}$ & $\mathrm{x}$ & $\mathrm{x}$ & & & $\mathrm{x}$ & & & & $\mathrm{x}$ & & \\
\hline Requisitos de embalagem & $\mathrm{x}$ & $\mathrm{x}$ & $\mathrm{x}$ & & & $\mathrm{x}$ & & & & & & \\
\hline Etiquetagem e marcação & $\mathrm{x}$ & $\mathrm{x}$ & $\mathrm{x}$ & $\mathrm{x}$ & $\mathrm{x}$ & $\mathrm{x}$ & $\mathrm{x}$ & $\mathrm{x}$ & $\mathrm{x}$ & $\mathrm{x}$ & $\mathrm{x}$ & $\mathrm{x}$ \\
\hline Documentação & $\mathrm{x}$ & & $\mathrm{x}$ & $\mathrm{x}$ & & $\mathrm{x}$ & $\mathrm{x}$ & & & & & \\
\hline Procedimentos de aceitação & & & & & & $\mathrm{x}$ & & & & & & \\
\hline $\begin{array}{l}\text { Reconhecimento de artigo } \\
\text { perigoso não declarado }\end{array}$ & $\mathrm{x}$ & $\mathrm{x}$ & $\mathrm{x}$ & $\mathrm{x}$ & $\mathrm{x}$ & $\mathrm{x}$ & $\mathrm{x}$ & $\mathrm{x}$ & $\mathrm{x}$ & $\mathrm{x}$ & $\mathrm{x}$ & $\mathrm{x}$ \\
\hline $\begin{array}{l}\text { Procedimentos de armazenagem e } \\
\text { carregamento }\end{array}$ & & & & & $\mathrm{x}$ & $\mathrm{x}$ & & $\mathrm{x}$ & & $\mathrm{x}$ & & \\
\hline Notificação ao comandante & & & & & & $\mathrm{x}$ & & $\mathrm{x}$ & & $\mathrm{x}$ & & \\
\hline $\begin{array}{l}\text { Provisões para passageiros e } \\
\text { tripulantes }\end{array}$ & $\mathrm{x}$ & $\mathrm{x}$ & $\mathrm{x}$ & $\mathrm{x}$ & $\mathrm{x}$ & $\mathrm{x}$ & $\mathrm{x}$ & $\mathrm{x}$ & $\mathrm{x}$ & $\mathrm{x}$ & $\mathrm{x}$ & $\mathrm{x}$ \\
\hline Procedimentos de emergência & $\mathrm{x}$ & $\mathrm{x}$ & $\mathrm{x}$ & $\mathrm{x}$ & $\mathrm{x}$ & $\mathrm{x}$ & $\mathrm{x}$ & $\mathrm{x}$ & $\mathrm{x}$ & $\mathrm{x}$ & $\mathrm{x}$ & $\mathrm{x}$ \\
\hline
\end{tabular}

\section{CATEGORIAS}

1 - Expedidores e pessoas que assumem as responsabilidades dos expedidores, incluindo os funcionários dos operadores aéreos que atuam como expedidor de COMAT classificado como artigo perigoso.

2 - Pessoas responsáveis pelo preparo da embalagem com artigo perigoso - embalador.

3 - Funcionários das agências de carga aérea envolvidos no processamento de artigos perigosos.

4 - Funcionários das agências de carga aérea envolvidos no processamento da carga e mala postal (exceto artigos perigosos).

5- Funcionários das agências de carga aérea envolvidos no manuseio, armazenagem e capatazia da carga ou mala postal.

6- Funcionários dos operadores aéreos e agentes de manuseio em solo que realizam procedimento de aceitação de artigos perigosos.

7 - Funcionários dos operadores aéreos e agentes de manuseio em solo que realizam procedimento de aceitação de carga ou mala postal (exceto de artigos perigosos).

8 - Funcionários dos operadores aéreos e agentes de manuseio em solo, envolvidos no manuseio, na armazenagem e na capatazia de carga ou mala postal e bagagem.

9 - Funcionários de atendimento aos passageiros.

10 - Membros da tripulação de voo (pilotos, mecânicos de voo e navegadores), supervisores de carregamento, planejadores de carregamento e encarregados de operações de voo/despachantes de voo.

11 - Membros da tripulação de cabine (comissários).

12 - Funcionários de segurança da aviação civil contra atos de interferência ilícita encarregados da inspeção dos passageiros e tripulantes, incluindo suas bagagens, e da carga ou mala postal.

Origem: SPO 


\section{ANEXO 3 - Cronograma do curso de artigos perigosos ANAC}

(continua)

Data de emissão: 6 de julho de 2018 .

IS n ${ }^{\circ} 175-002$

Revisão E

\section{APÊNDICE C - TABELA DE CONTEÚDO SUGERIDO PARA O CURSO DE ARTIGOS PERIGOSOS}

\begin{tabular}{|c|c|c|}
\hline Disciplina / Conteúdos & $\begin{array}{c}\text { Instruções } \\
\text { Técnicas } \\
\text { (Parte;Item) } \\
\end{array}$ & $\begin{array}{l}\text { Regulamentos } \\
\text { Brasileiros }\end{array}$ \\
\hline \multicolumn{3}{|l|}{ Filosofia Geral } \\
\hline 1. Propósito do treinamento em transporte aéreo de artigos perigosos & $\begin{array}{l}1 ; 4, \text { Introductory } \\
\text { Note, } 1 ; 4.1\end{array}$ & $\begin{array}{l}\text { IS n }{ }^{\circ} 175-002 \\
\text { IS n } \\
\text { o } 175-007\end{array}$ \\
\hline 2. Materiais regulatórios aplicáveis & Foreword; $1 ; 1,1 ; 2$ & $\begin{array}{l}\mathrm{RBAC} \mathrm{n}^{\circ} 175 \mathrm{e} \\
\text { IS } \\
\text { correspondentes }\end{array}$ \\
\hline 3. Uso das Instruções Técnicas ou do DGR IATA & $1 ; 1.1$ & \\
\hline 4. Definições utilizadas no transporte aéreo de artigos perigosos & $1 ; 3.1$ & $\begin{array}{l}\mathrm{RBAC} \mathrm{n}^{\circ} 175 \mathrm{e} \\
\text { IS } \\
\text { correspondentes }\end{array}$ \\
\hline 5. Requisitos gerais de transporte & $1 ; 1.2$ & \\
\hline 6. Transporte por aeronave & $1 ; 1.1 .1$ & \\
\hline 7. Requisitos e registros de treinamento & $1 ; 4$ & $\begin{array}{l}\text { IS n }^{\circ} 175-002 \\
\text { IS n }^{\circ} 175-007\end{array}$ \\
\hline 8. Segurança de artigos perigosos contra atos de interferência ilícita & $1 ; 5$ & \\
\hline \multicolumn{3}{|l|}{ Limitações } \\
\hline 1. Artigos perigosos proibidos em aeronave & $1 ; 2.1$ & $\begin{array}{l}\text { RBAC n } 175 \\
\text { IS n } n^{\circ} 175-008\end{array}$ \\
\hline 2. Exceções gerais & $1 ; 1.1 .5$ & \\
\hline 3. Exceções para COMAT perigoso & $1 ; 2.2$ & \\
\hline 4. Transporte de artigos perigosos por mala postal & $1 ; 2.3$ & $175.5(\mathrm{i})$ \\
\hline 5. Artigos perigosos em quantidades excetuadas & $1 ; 2.4,3 ; 5.1$ & \\
\hline 6. Exceções para artigos perigosos embalados em quantidades limitadas & $1 ; 2.5,3 ; 4.1$ & \\
\hline \multicolumn{3}{|l|}{ Requisitos gerais para os expedidores } \\
\hline $\begin{array}{l}\text { 1. Responsabilidades específicas dos expedidores e cumprimento da } \\
\text { regulamentação }\end{array}$ & $1 ; 1.2,5 ; 1.1$ & 175.17 \\
\hline \multicolumn{3}{|l|}{ Classificação } \\
\hline 1. Classificação de artigos perigosos & Parte 2 & \\
\hline \multicolumn{3}{|l|}{ Lista de artigos perigosos } \\
\hline 1. Propósito e utilização da tabela de artigos perigosos & $3 ; 1.1,3 ; 2$ & \\
\hline 2. Nome apropriado para embarque & $2 ; 0.3,3 ; 1.2$ & \\
\hline 3. Classe de risco (definição) & $2 ; 0.2$ & \\
\hline 4. Números UN/ID & $2 ; 0.3, \mathrm{~A}-1 ; 1$ & \\
\hline 5. Grupo de embalagem & $2 ; 0.2 .4,4 ; 1.2$ & \\
\hline 6. Provisões especiais & $3 ; 3$ & \\
\hline \multicolumn{3}{|l|}{ Requisitos de embalagem } \\
\hline Origem: SPO & & $20 / 31$ \\
\hline
\end{tabular}


(continuação)

\begin{tabular}{|c|c|c|}
\hline 1. Requisitos gerais de embalagem & $4 ; 1.1$ & \\
\hline 2. Instruções de embalagem & $4 ; 2,4 ; 3$ & \\
\hline \multicolumn{3}{|l|}{ Etiquetagem e marcação } \\
\hline 1. Marcas requeridas para volumes contendo artigos perigosos & $5 ; 2$ & \\
\hline 2. Etiquetas requeridas para volumes contendo artigos perigosos & $5 ; 3$ & \\
\hline \multicolumn{3}{|l|}{ Declaração do expedidor e documentação pertinente } \\
\hline 1. Declaração do expedidor de artigo perigoso & $5 ; 4.1$ & \\
\hline 2. Conhecimento aéreo (AWB e CT-e) & $5 ; 4.2$ & IS $n^{\circ} 175-003$ \\
\hline 3. Documentação adicional & $5 ; 4.3$ & \\
\hline 4. Arquivamento da documentação & $5 ; 4.4,7 ; 4.11$ & \\
\hline \multicolumn{3}{|l|}{ Procedimentos de aceitação } \\
\hline 1. Requisitos e procedimentos para aceitação e recusa de artigos perigosos & $7 ; 1$ & \\
\hline 2. Provisão de informação para expedidores & $7 ; 4.8$ & $175.15(f)$ \\
\hline 3. Aceitação de volumes e ULDs & $7 ; 1.3,7 ; 1.4$ & \\
\hline \multicolumn{3}{|l|}{ Reconhecimento de artigos perigosos não declarados } \\
\hline 1. Reconhecimento de artigos perigosos não declarados & $7 ; 6.1$ & \\
\hline \multicolumn{3}{|l|}{ Procedimentos de armazenagem e carregamento } \\
\hline 1. Classificação de compartimentos & Doc 9481 & \\
\hline 2. Carregamento de volumes & $7 ; 2.1,7 ; 2.4 .1$ & \\
\hline 3. Afixação de volumes & $7 ; 2.4 .2$ & \\
\hline 4. Artigos perigosos incompatíveis & $7 ; 2.2$ & \\
\hline 5. Preparação e inspeção de volumes e ULD & $7 ; 2.8,7 ; 3.1$ & \\
\hline 6. Outros requisitos de armazenagem e carregamento & $7 ; 2$ & \\
\hline 7. Danos causados por embarques de artigos perigosos & $7 ; 3.3$ & \\
\hline \multicolumn{3}{|l|}{ Notificação ao comandante } \\
\hline 1. NOTOC & $7 ; 4.1$ & IS n $^{\circ} 175-001$ \\
\hline 2. Informação de resposta a emergências & $7 ; 4.2,7 ; 4.3,7 ; 4.7$ & \\
\hline 3. Informação sobre bagagem contendo artigo perigoso & $8 ; 1$ & \\
\hline \multicolumn{3}{|l|}{ Provisões para passageiros e tripulantes } \\
\hline 1. Provisão de informação para passageiros & $7 ; 5.1$ & \\
\hline 2. Exceções para passageiros e tripulantes & $8 ; 1.1$ & 175.11 \\
\hline \multicolumn{3}{|l|}{ Procedimentos de emergência } \\
\hline 1. Uso do Doc 9481 ou documento similar & $7 ; 4.9$, Doc 9481 & \\
\hline 2. Notificação de ocorrências com artigos perigosos & $\begin{array}{c}1 ; 7,7 ; 4.4,7 ; 4.5 \\
7 ; 4.6,7.4 .7\end{array}$ & IS n $^{\circ} 175-005$ \\
\hline
\end{tabular}

Nota - Os assuntos listados na tabela anterior devem contemplar especificidades necessárias para a atuação dos funcionários em treinamento. Exemplo: Para operadores aéreos que transportem material radioativo, bateria de íons de lítio e substância biológica, Categoria $\mathrm{B}$, os itens do conteúdo programático dos treinamentos providos a seus funcionários devem contemplar esses assuntos.

Origem: SPO 


\section{ANEXO 4 - Tabela das necessidades de formação traduzida do Código IMDG}

(continua)

CÓDIGO IMDG - PARTES 1 a 5

1.3.1.5 Necessidades de formação recomendadas para o pessoal de terra envolvido no transporte de produtos perigosos de acordo com o Código IMDG

A tabela indicativa a seguir tem somente o propósito de fornecer informações, uma vez que toda entidade está organizada de maneira diferente e pode ter dentro dela atribuições e responsabilidades diversas.

\begin{tabular}{|c|c|c|c|}
\hline & Função & Requisitos de Formação Específicos & $\begin{array}{l}\text { Os números nesta } \\
\text { coluna referem-se à } \\
\text { lista de Códigos e } \\
\text { Publicações Correlatas } \\
\text { relacionados em } 1.3 .1 .7\end{array}$ \\
\hline 1 & $\begin{array}{l}\text { Classificar } \\
\text { produtos perigosos } \\
\text { e identificar o } \\
\text { Nome Apropriado } \\
\text { para Embarque }\end{array}$ & $\begin{array}{l}\text { Requisitos relativos à classificação, em especial } \\
\text { - } \quad \text { a estruturação da descrição das substâncias } \\
\text { - } \\
\text { as classes de produtos perigosos e os princípios } \\
\text { da sua classificação } \\
\text { - } \quad \text { a natureza das substâncias e artigos perigosos } \\
\text { transportados (suas propriedades físicas, } \\
\text { químicas e toxicológicas) } \\
\text { - } \quad \text { o procedimento para classificar soluções e } \\
\text { misturas } \\
\text { - identificação pelo Nome Apropriado para } \\
\text { Embarque } \\
\text { - uso da Lista de Produtos perigosos }\end{array}$ & $.1, .4, .5 \mathrm{e} .12$ \\
\hline 2 & $\begin{array}{l}\text { Embalar produtos } \\
\text { perigosos }\end{array}$ & $\begin{array}{l}\text { Classes } \\
\text { Requisitos relativos às Embalagens } \\
\text { - } \quad \text { tipos de volumes (IBC, embalagens grandes, } \\
\text { - } \quad \text { manques e contêineres para granáo da ONU para embalagens aprovadas } \\
\text { - } \quad \text { exigências relativas à segregação } \\
\text { - } \quad \text { quantidades limitadas e quantidades isentadas } \\
\text { Marcação e rotulagem } \\
\text { Medidas relativas a primeiros socorros } \\
\text { Procedimentos de reação a emergência } \\
\text { Procedimentos de manuseio com segurança }\end{array}$ & $.1 \mathrm{e} .4$ \\
\hline 3 & $\begin{array}{l}\text { Marcar, rotular ou } \\
\text { afixar cartazes em } \\
\text { produtos perigosos }\end{array}$ & $\begin{array}{l}\text { Classes } \\
\text { Exigências relativas à marcação, rotulagem e afixação } \\
\text { de cartazes } \\
\text { - } \quad \text { rótulos de risco principal e subsidiário } \\
\text { - } \quad \text { poluentes marinhos } \\
\text { - } \quad \text { quantidades limitadas e quantidades isentadas }\end{array}$ & .1 \\
\hline 4 & $\begin{array}{l}\text { Carregar e } \\
\text { descarregar } \\
\text { unidades de } \\
\text { transporte de } \\
\text { carga }^{11}\end{array}$ & $\begin{array}{l}\text { Documentação } \\
\text { Classes } \\
\text { Marcação, rotulagem e afixação de cartazes } \\
\text { Exigências relativas à estivagem, quando aplicável } \\
\text { Exigências relativas à segregação } \\
\text { Exigências relativas à peiação da carga (como } \\
\text { contidas nas diretrizes da IMO/ILO/UNECE) } \\
\text { Procedimentos de reação a emergências } \\
\text { Medidas relativas aos primeiros socorros } \\
\text { Exigências da Convenção Internacional para } \\
\text { Contêineres Seguros (CSC) } \\
\text { Procedimentos de manuseio com segurança }\end{array}$ & $.1, .6, .7$ e .8 \\
\hline
\end{tabular}

\footnotetext{
11 Definição como constante nas Diretrizes da IMO/ILO/UNECE para o Acondicionamento de Unidades de Transporte de Carga
} 
(continuação)

CÓDIGO IMDG - PARTES 1 a 5

\begin{tabular}{|c|c|c|c|}
\hline & Função & Requisitos de Formação Específicos & $\begin{array}{l}\text { Os números nesta } \\
\text { coluna referem-se à } \\
\text { lista de Códigos e } \\
\text { Publicações Correlatas } \\
\text { relacionados em 1.3.1.7 }\end{array}$ \\
\hline 5 & $\begin{array}{l}\text { Elaborar } \\
\text { documentos de } \\
\text { transporte para } \\
\text { produtos perigosos }\end{array}$ & $\begin{array}{ll}\text { Exigências relativas à documentação } \\
\text { - } & \text { documento de transporte } \\
\text { - } & \text { certificado de acondicionamento em } \\
\text { - } & \text { contêiner/veículo } \\
\text { - } & \text { aprovação das autoridades competentes } \\
\text { - } & \text { documentação para transporte de resíduos } \\
& \text { docuão especial, quando for adequado }\end{array}$ & .1 \\
\hline 6 & $\begin{array}{l}\text { Oferecer produtos } \\
\text { perigosos para } \\
\text { transporte }\end{array}$ & $\begin{array}{l}\text { Conhecimento profundo do Código IMDG } \\
\text { Exigências locais nos portos de carregamento e de } \\
\text { descarga } \\
\text { - regulamentos do porto } \\
\text { - } \text { regras nacionais de transporte }\end{array}$ & $.1 \mathrm{a} .10 \mathrm{e} .12$ \\
\hline 7 & $\begin{array}{l}\text { Aceitar produtos } \\
\text { perigosos para } \\
\text { transporte }\end{array}$ & $\begin{array}{l}\text { Conhecimento profundo do Código IMDG } \\
\text { Exigências locais nos portos de carregamento, de } \\
\text { trânsito e de descarga } \\
\text { - regulamentos dos portos, em especial as } \\
\text { - } \quad \text { regrações nacionais de transporte } \\
\end{array}$ & $.1 \mathrm{a} .12$ \\
\hline 8 & $\begin{array}{l}\text { Manusear produtos } \\
\text { perigosos durante o } \\
\text { transporte }\end{array}$ & $\begin{array}{l}\text { Classes e seus riscos } \\
\text { Marcação, rotulagem e afixação de cartazes } \\
\text { Procedimentos de reação a emergência } \\
\text { Medidas relativas a primeiros socorros } \\
\text { Procedimentos de manuseio com segurança, tais } \\
\text { como } \\
-\quad \text { utilização de equipamentos } \\
-\quad \text { ferramentas apropriadas } \\
\text { - cargas de trabalho seguras } \\
\text { Exigências relativas à Convenção Internacional para } \\
\text { Contêineres Seguros (CSC), exigências locais nos } \\
\text { portos de carregamento, de trânsito e de descarga } \\
\text { Regulamentos dos portos, em especial as limitações } \\
\text { de quantidade } \\
\text { Regras nacionais de transporte }\end{array}$ & $.1, .2, .3, .6, .7, .8 \mathrm{e} .10$ \\
\hline 9 & $\begin{array}{l}\text { Elaborar planos de } \\
\text { carregamento/ } \\
\text { estivagem de } \\
\text { produtos perigosos }\end{array}$ & $\begin{array}{l}\text { Documentação } \\
\text { Classes } \\
\text { Exigências relativas à estivagem } \\
\text { Exigências relativas à segregação } \\
\text { Documento de conformidade } \\
\text { Partes pertinentes do Código IMDG, exigências } \\
\text { locais nos portos de carregamento, de trânsito e de } \\
\text { descarga } \\
\text { Regulamentos dos portos, em especial as limitações } \\
\text { de quantidade }\end{array}$ & $.1, .10, .11 \mathrm{e} .12$ \\
\hline
\end{tabular}


(continuação)

CÓDIGO IMDG - PARTES 1 a 5

\begin{tabular}{|c|c|c|c|}
\hline \multicolumn{2}{|r|}{ Função } & Requisitos de Formação Específicos & $\begin{array}{l}\text { Os números nesta } \\
\text { coluna referem-se à } \\
\text { lista de Códigos e } \\
\text { Publicações Correlatas } \\
\text { relacionados em 1.3.1.7 }\end{array}$ \\
\hline 10 & $\begin{array}{l}\text { Carregar produtos } \\
\text { perigosos em } \\
\text { navios e } \\
\text { descarregar } \\
\text { produtos perigosos } \\
\text { de navios }\end{array}$ & $\begin{array}{l}\text { Classes e seus riscos } \\
\text { Marcação, rotulagem e afixação de cartazes } \\
\text { Procedimentos de reação a emergência } \\
\text { Medidas relativas a primeiros socorros } \\
\text { Procedimentos de manuseio com segurança, tais como } \\
\text { - utilização de equipamentos } \\
\text { - } \quad \text { ferramentas apropriadas } \\
\text { - cargas de trabalho seguras } \\
\text { Exigências relativas à peiação da carga } \\
\text { Exigências da Convenção Internacional para } \\
\text { Contêineres Seguros (CSC), exigências locais nos } \\
\text { portos de carregamento, de trânsito e de descarga } \\
\text { Regulamentos dos portos, em especial as limitações } \\
\text { de quantidade } \\
\text { Regras nacionais de transporte }\end{array}$ & $.1, .2, .3, .7, .9, .10 \mathrm{e} .12$ \\
\hline & $\begin{array}{l}\text { Transportar } \\
\text { produtos perigosos }\end{array}$ & $\begin{array}{l}\text { Documentação } \\
\text { Classes } \\
\text { Marcação, rotulagem e afixação de cartazes } \\
\text { Exigências relativas à estivagem, quando for aplicável } \\
\text { Exigências relativas à segregação } \\
\text { Exigências locais nos portos de carregamento, de } \\
\text { trânsito e de descarga } \\
\text { - regulamentos dos portos, em especial as } \\
\quad \text { limitações de quantidade } \\
\text { - regras nacionais de transporte } \\
\text { Exigências relativas à peiação da carga (como } \\
\text { contidas nas diretrizes da IMO/ILO/UNECE) } \\
\text { Procedimentos de reação a emergências } \\
\text { Medidas relativas aos primeiros socorros } \\
\text { Exigências da Convenção Internacional para } \\
\text { Contêineres Seguros (CSC) } \\
\text { Procedimentos de manuseio com segurança } \\
\end{array}$ & $\begin{array}{l}.1, .2, .3, .6, .7, .10, .11 \mathrm{e} \\
.12\end{array}$ \\
\hline 12 & $\begin{array}{l}\text { Vistoriar ou } \\
\text { inspecionar para } \\
\text { impor o } \\
\text { cumprimento das } \\
\text { leis e regulamentos } \\
\text { aplicáveis }\end{array}$ & $\begin{array}{l}\text { Conhecimento do Código IMDG e das diretrizes e } \\
\text { procedimentos de segurança pertinentes }\end{array}$ &, $1 \mathrm{a} .12$ \\
\hline 13 & $\begin{array}{l}\text { Pessoal envolvido } \\
\text { de outra maneira } \\
\text { no transporte de } \\
\text { produtos } \\
\text { perigosos, como } \\
\text { determinado pela } \\
\text { autoridade } \\
\text { competente }\end{array}$ & $\begin{array}{l}\text { Como exigido pela autoridade competente, de } \\
\text { maneira proporcional às tarefas atribuídas }\end{array}$ & - \\
\hline
\end{tabular}

